\title{
Hydrochemistry and Hydrogeologic Conditions Within the Hanford Site Upper Basalt Confined Aquifer System
}

\author{
F. A. Spane, Jr. \\ W. D. Webber
}

September 1995

Prepared for

the U.S. Department of Energy

under Contract DE-AC06-76RLO 1830

Pacific Northwest Laboratory

Richland, Washington 99352 


\section{DISCLAIMER}

This report was prepared as an account of work sponsored by an agency of the United States Government. Neither the United States Government nor any agency thereof, nor any of their employees, make any warranty, express or implied, or assumes any legal liability or responsibility for the accuracy, completeness, or usefulness of any information, apparatus, product, or process disclosed, or represents that its use would not infringe privately owned rights. Reference herein to any specific commercial product, process, or service by trade name, trademark, manufacturer, or otherwise does not necessarily constitute or imply its endorsement, recommendation, or favoring by the United States Government or any agency thereof. The views and opinions of authors expressed herein do not necessarily state or reflect those of the United States Government or any agency thereof. 


\section{DISCLAIMER}

Portions of this document may be illegible in electronic image products. Images are produced from the best available original document. 


\begin{abstract}
This report is the first comprehensive Hanford Site-wide report that integrates hydrogeologic information for the upper basalt confined aquifer system (i.e., the upper Saddle Mountains Basalt). Available data pertaining to hydrologic head conditions and hydraulic properties were combined with hydrochemical analytical results for selected wells completed within the upper basalt confined aquifer system. Interpretation of this information is important for evaluating aquifer-flow characteristics for this system.
\end{abstract}


. 


\section{Summary}

Pacific Northwest Laboratory ${ }^{(a)}$ is responsible for determining, as part of the Hanford Site Ground-Water Surveillance Project, the potential for offsite migration of contamination through the upper basalt confined aquifer system. During the past 40 years, hydrologic investigations of the upper basalt confined aquifer were conducted by a number of Hanford Site programs. Elements of the investigations included groundwater sample collection for hydrochemical characterization, hydrologic testing (slug and pumping tests) for hydraulic property determination, and well water-level monitoring for groundwater flow-pattern delineation and aquifer dynamics evaluation. Interpretation information obtained from these investigations is important for evaluating aquifer-flow characteristics for this system (e.g., delineating groundwater-flow patterns, determining flow velocity, assessing hydrologic interrelationship with the overlying unconfined aquifer).

This report is the first comprehensive Hanford Site-wide report that integrates hydrogeologic information for the upper basalt confined aquifer system (i.e., the upper Saddle Mountains Basalt). Available data pertaining to hydrologic head conditions (e.g., Spane and Raymond 1993) and hydraulic properties (Spane and Vermeul 1994) were combined with hydrochemical analytical results for selected wells completed within the upper basalt confined aquifer system. Results of this data-integration analysis are summarized below.

\section{Hydrogeologic Conditions}

1. Hydrogeologic units within the upper basalt confined aquifer system that are capable of transmitting significant quantities of groundwater laterally include (in descending stratigraphic order) the Levey interbed, Elephant Mountain Member interflow zone, and Rattlesnake Ridge interbed. Because of its greater thickness and areal extent, the Rattlesnake Ridge interbed is considered to be the principal hydrogeologic unit within the aquifer system.

2. Recharge to hydrogeologic units of the upper basalt confined aquifer system occurs through a number of natural processes and man-related activities, including:

- direct recharge to the aquifer from precipitation and surface runoff (occurring primarily in the Rattlesnake Hills region and the Saddle Mountains, located along the southwestern and northern boundaries of the Hanford Site)

- pervasive recharge from the overlying unconfined aquifer (occurring within the western part of the Hanford Site, where a vertical downward head gradient is prevalent)

(a) Pacific Northwest Laboratory is operated for the U.S. Department of Energy by Battelle Memorial Institute. 
- artificial recharge from past and current Hanford Site wastewater-disposal practices (located in proximity to the 200 East Area)

- artificial recharge from agricultural irrigation practices (located primarily east of the Hanford Site).

3. Groundwater discharges from the upper basalt confined aquifer system primarily to the Columbia River, along the eastern-southeastern boundary of the Hanford Site. Geologic structures and erosional paleostream channels, however, in the Gable Mountain-Gable Butte structural area, north of the 200 East Area, also provide direct pathways for discharge from the upper basalt system to overlying and underlying aquifers. Pervasive discharge to the overlying unconfined aquifer also occurs within the eastern half of the Hanford Site, where vertical upward head gradients occur between the two aquifer systems.

4. The temporal behavior of hydraulic heads within the upper basalt confined aquifer system on the Hanford Site also exhibited two distinct trend patterns over the 41/2-year period (January 1991 through June 1995).

- for monitoring wells located along the eastern Hanford Site boundary, an annual increasing head pattern ranges between 0.02 and $0.36 \mathrm{~m} / \mathrm{yr}$ and is attributed to irrigation activities within the area east of the Columbia River. The fact that hydraulic head values continue to increase in this region indicates that equilibrium conditions have not been reestablished for the level of recharge from irrigation occurring in this area, and also supports the observation that the Columbia River does not form a dominant line-sink discharge area for groundwater within the upper basalt aquifer, along its entire reach within the Pasco Basin.

- for monitoring wells not located along the eastern Hanford Site boundary, an annual decreasing head pattern ranges between 0.08 and $0.24 \mathrm{~m} / \mathrm{yr}$, with the greatest declines occurring in the vicinity of the 200 Areas. The declining head patterns are similar to those reported for the overlying unconfined aquifer, which are attributed to the continuing decline in wastewater discharges to the unconfined aquifer in the 200 Areas.

\section{Hydrochemical Characteristics}

1. The hydrochemical characteristics of groundwater within the upper basalt confined aquifer system reflect the evolution and interaction of various processes within the system. Generally, less-chemically evolved groundwater within the aquifer system is represented by a predominant calcium, magnesium-bicarbonate $\left(\mathrm{Ca}, \mathrm{Mg}-\mathrm{HCO}_{3}\right)$ chemical water type. With increased aquiferresidence time and longer flow paths, groundwaters have a greater opportunity for chemical interaction with the aquifer matrix. Consequently, the cation composition of the groundwater evolves to a predominantly sodium ( $\mathrm{Na}$ ) character. The evolution of the upper basalt aquifer groundwaters to an $\mathrm{Na}-\mathrm{HCO}_{3}$ chemical water type is attributed to a number of geochemical processes, including 
calcite $\left(\mathrm{CaCO}_{3}\right)$ precipitation/mineral equilibria controls, cation-exchange processes, and $\mathrm{Na}$ increases as a result of volcanic glass hydrolysis/dissolution reactions.

2. Upper basalt groundwaters can be characterized as dilute solutions, generally having total dissolved solids contents $\leq 250 \mathrm{mg} / \mathrm{L}$. Principal inorganic constituents include $\mathrm{Ca}^{+2}, \mathrm{Na}^{+2}, \mathrm{Mg}^{+2}, \mathrm{HCO}_{3}^{-}$, sulfate $\left(\mathrm{SO}_{4}^{-2}\right)$, and silica $\left(\mathrm{SiO}_{2}\right)$. Considerable variability in the range of major inorganic concentrations is exhibited. This is largely attributed to the source and distance to locations of recharge (natural versus artificial), degree of aquifer intercommunication, and progression of hydrochemical evolutionary patterns within the upper basalt confined aquifer system.

3. Of particular interest is the variation of nitrate $\left(\mathrm{NO}_{3}^{-}\right)$content within the Hanford Site upper basalt confined aquifer system. The presence of elevated $\mathrm{NO}_{3}^{-}$concentrations within hydrogeologic units of the upper basalt aquifer system was utilized by previous investigators as a hydrochemical indicator of aquifer intercommunication and/or groundwater mixing with the overlying contaminated unconfined aquifer. The majority of onsite wells (i.e., $>92 \%$ ) exhibiting $\mathrm{NO}_{3}^{-}$ concentrations $>1.0 \mathrm{mg} / \mathrm{L}$ are located in the vicinity of the 200 East Area and Gable Mountain.

4. Comparison of stable deuterium $\left({ }^{2} \mathrm{H}\right)$ and oxygen-18 $\left({ }^{18} \mathrm{O}\right)$ isotopic data for upper basalt groundwaters and river and spring waters indicates a number of distinct grouping differences and associations, including:

- generally lighter stable isotopic content for the upper basalt confined aquifer system

- distinct groupings for Columbia River and Yakima River waters

- association between southern offsite wells and Yakima River waters.

5. The ${ }^{2} \mathrm{H}$ and ${ }^{18} \mathrm{O}$ content of upper basalt aquifer groundwaters is similar isotopically to local precipitation that occurs during the winter months in the Rattlesnake Hills area. This suggests that precipitation that recharged the upper basalt aquifer in the past was consistent with current climatic conditions occurring in this known natural recharge area for the upper basalt confined aquifer system.

\section{Aquifer Intercommunication}

1. Available hydrogeologic, hydraulic head, and hydrochemical data indicate that the principal area of intercommunication between the upper basalt confined aquifer and the unconfined aquifer occurs in the area immediately north of the 200 East Area. Hydraulic intercommunication is attributed to the absence of upper basalt hydrogeologic confining units, structural deformation, and presence of erosional paleostream channels in this region. 
2. Direct evidence for contamination of the upper basalt confined aquifer system from the overlying unconfined aquifer within this region is indicated by the presence of a variety of hydrochemical parameters, including:

- elevated concentration levels for tritium $\left({ }^{3} \mathrm{H}\right), \mathrm{NO}_{3}^{-}$, and carbon-14 $\left({ }^{14} \mathrm{C}\right)$

- a change in hydrochemical cation facies from an expected $\mathrm{Na}$ or $\mathrm{Na}-\mathrm{Ca}$ to a $\mathrm{Ca}$ or $\mathrm{Ca}-\mathrm{Mg}$ water type.

3. Not all of the hydrochemical indicators are required to be present to indicate intercommunication and presence of a component of the unconfined aquifer groundwater within the upper basalt confined aquifer system. This is due, in part, to spatial variation of hydrochemical parameters and contaminant levels within the overlying unconfined aquifer.

4. Most upper basalt aquifer wells in the vicinity of the 200 East Area and Gable Mountain exhibit a degree of groundwater mixing with the overlying unconfined aquifer.

5. Offsite upper basalt aquifer wells located immediately south of the Yakima River also exhibit hydrochemical parameters that are indicative of a recent recharge component of Yakima River water, which is likely associated with agricultural/irrigation practices and/or direct river-aquifer water transference in this area. Hydrochemical evidence supporting this finding includes similarities in stable $\left({ }^{2} \mathrm{H},{ }^{18} \mathrm{O}\right.$, sulfur-34 $\left.\left[{ }^{34} \mathrm{~S}\right]\right)$ and unstable $\left({ }^{3} \mathrm{H},{ }^{14} \mathrm{C}\right)$ isotope composition, hydrochemical water type $\left(\mathrm{Ca}, \mathrm{Mg}-\mathrm{HCO}_{3}\right)$, and elevated $\mathrm{NO}_{3}^{-}$concentration.

\section{Potential for Offsite Migration of Contaminants}

1. Contamination within the upper basalt confined aquifer system has a number of identified potential offsite migration pathways. These potential offsite pathways include:

- across the eastern-southeastern boundary of the Hanford Site

- transference to deeper confined aquifers in the Gable Mountain-Gable Butte structural area

- across the southern boundary of the Hanford Site.

2. The potential for offsite migration across the eastern-southeastern boundary of the Hanford Site is considered minor because of low lateral flow velocities for groundwater along this flow path in the upper basalt system, the indication that the Columbia River forms a dominant line-sink discharge area for the aquifer system in this region, and the presence of high hydraulic head conditions to the east of the river. 
3. The potential for offsite migration through transference to underlying transmissive Wanapum Basalt aquifers in the Gable Mountain-Gable Butte structural area is uncertain. Contaminated groundwater within the upper basalt confined aquifer system in this region flows downward to the underlying Saddle Mountains Basalt and to deeper aquifers within the Wanapum Basalt. Aquifers within the Wanapum Basalt are regionally important offsite sources of groundwater for agricultural and domestic use. The degree of contamination within the underlying Wanapum Basalt aquifers is largely unknown. However, because of the high hydraulic conductivity values reported for some Wanapum Basalt interflow aquifers, their deep hydrogeologic setting, and offsite use, a potential exists for offsite migration of contaminants through this pathway. Any contamination within the underlying Wanapum Basalt aquifers would be significantly reduced by dilution within these units prior to migrating offsite through this pathway.

4. The potential also exists for offsite migration within the upper basalt confined aquifer system across the southern boundary of the Hanford Site. This is based on the assumption that the Yakima River does not represent a dominant line-sink discharge or line-source recharge area for the upper basalt aquifer system. The possibility for offsite migration along this potential flow path is highly uncertain because of the paucity of hydrogeologic, hydraulic property, and hydrochemical information for the upper basalt aquifer system in this area. However, the presence of offsite municipal, agricultural, and domestic users of groundwater from the upper basalt aquifer south of the Hanford Site and forecasted development in this area warrant further investigation of this potential contaminant pathway. 



\section{Acknowledgments}

Several people contributed to the development of this report. In particular, important technical peer review comments were provided by P. D. Thorne. In addition, the editorial review and guidance by B. V. Johnston and S. P. Luttrell are also acknowledged. Special thanks are also extended to M. S. Witkowski for performing linear regression analysis of temporal hydraulic head response for selected wells monitoring the upper basalt confined aquifer system. 



\section{Contents}

Abstract $\ldots \ldots \ldots \ldots \ldots \ldots \ldots \ldots \ldots \ldots \ldots \ldots \ldots \ldots \ldots \ldots \ldots \ldots \ldots \ldots$

Summary $\ldots \ldots \ldots \ldots \ldots \ldots \ldots \ldots \ldots \ldots \ldots \ldots \ldots \ldots \ldots \ldots$

Acknowledgments $\ldots \ldots \ldots \ldots \ldots \ldots \ldots \ldots \ldots \ldots \ldots \ldots \ldots \ldots \ldots \ldots$

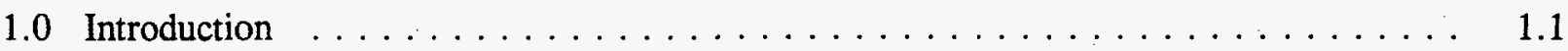

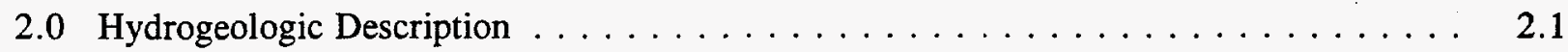

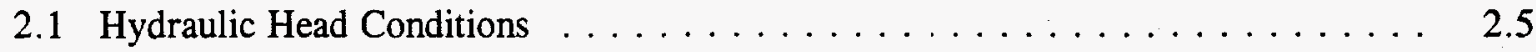

2.2 Flow System Dynamics $\ldots \ldots \ldots \ldots \ldots \ldots \ldots \ldots \ldots \ldots \ldots \ldots \ldots \ldots$

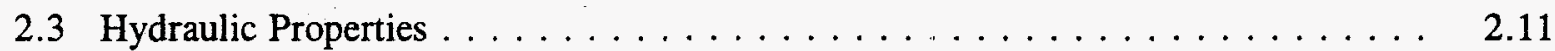

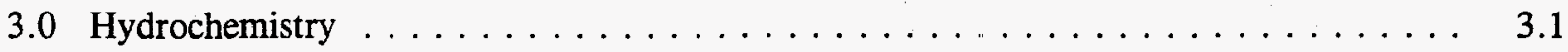

3.1 Hydrochemical Evolutionary Patterns $\ldots \ldots \ldots \ldots \ldots \ldots \ldots \ldots \ldots \ldots$

3.2 Major Inorganic Constituents $\ldots \ldots \ldots \ldots \ldots \ldots \ldots \ldots \ldots \ldots \ldots$

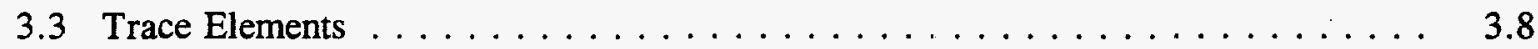

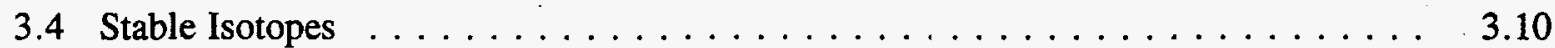

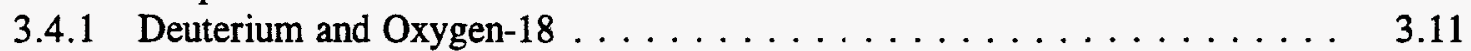

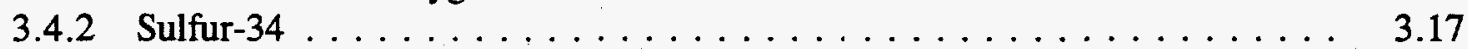

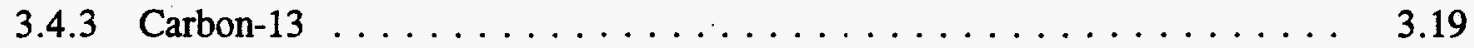

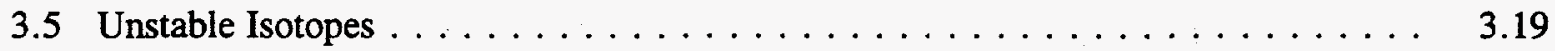

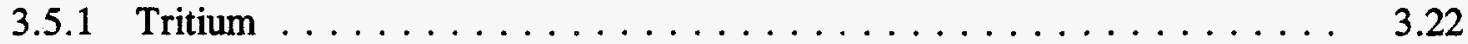

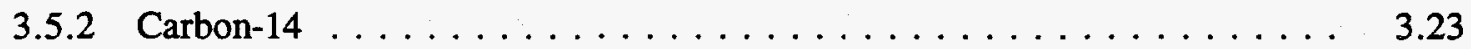

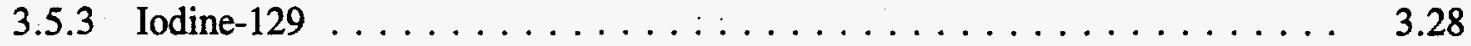

4.0 Groundwater-Flow Characteristics $\ldots \ldots \ldots \ldots \ldots \ldots \ldots \ldots \ldots \ldots \ldots$

4.1 Evidence for Aquifer Intercommunication/Aquifer Contamination $\ldots \ldots \ldots .1$

4.2 Potential for Offsite Migration $\ldots \ldots \ldots \ldots \ldots \ldots \ldots \ldots$

5.0 References $\ldots \ldots \ldots \ldots \ldots \ldots \ldots \ldots \ldots \ldots \ldots \ldots \ldots \ldots \ldots \ldots \ldots$

Appendix - Hydrochemical Data Summary Tables $\ldots \ldots \ldots \ldots \ldots \ldots \ldots$. . . . . . 


\section{Figures}

2.1 General Stratigraphic Relationships Within the Pasco Basin $\ldots \ldots \ldots \ldots \ldots \ldots$

2.2 Isopach Map of the Rattlesnake Ridge Interbed on the Hanford Site $\ldots \ldots \ldots \ldots$

2.3 Potentiometric Map of the Upper Basalt Confined Aquifer System - March 1993 . . . . . 2.6

2.4 Location of Monitoring Wells Used for Evaluating Flow Dynamic Characteristics of the Upper Basalt Confined Aquifer System $\ldots \ldots \ldots \ldots \ldots \ldots \ldots$

2.5 Comparison of Slug and Constant-Rate Pumping Test Analysis Results for Upper Basalt Confined Aquifer System Test Intervals . . . . . . . . . . . . . . 2.13

2.6 Distribution of Transmissivity Estimates for Individual Hydrogeologic Units Within

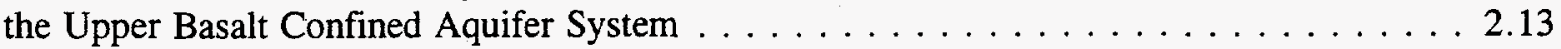

3.1 Location of Upper Basalt Confined Aquifer System Groundwater Well-Sampling Sites . . . . 3.2

3.2 Trilinear Diagram, Showing Hydrochemical Evolution of Groundwater Within the

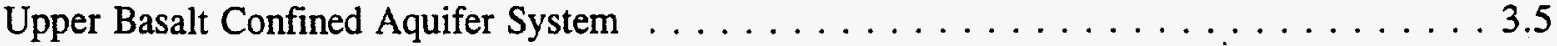

3.3 Hydrochemical Facies Stiff Diagram Map for Groundwater Within the Upper Basalt

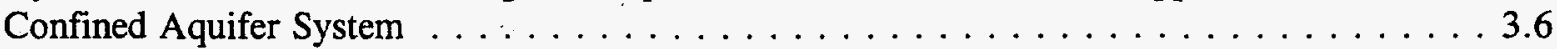

3.4 Relationship of $\delta^{2} \mathrm{H}$ and $\delta^{18} \mathrm{O}$ for the Upper Basalt Confined Aquifer System and Selected

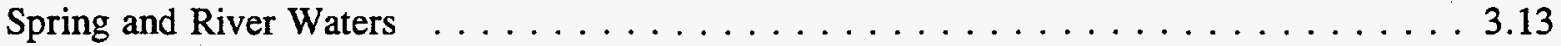

3.5 Histograms Showing the Frequency Distribution of $\delta^{2} \mathrm{H}$ Within the (a) Upper Basalt Confined Aquifer System and (b) Rivers and Springs on the Hanford Site . . . . . . . . 3.15

3.6 Histograms Showing the Frequency Distribution of $\delta^{18} \mathrm{O}$ Within the (a) Upper Basalt Confined Aquifer System and (b) Rivers and Springs on the Hanford Site . . . . . . . 3.16

3.7. Histograms Showing the Frequency Distribution of $\delta^{34} S$ Within the (a) Upper Basalt Confined Aquifer System and (b) Rivers and Springs on the Hanford Site . . . . . . . . 3.18

3.8 Histograms Showing the Frequency Distribution of $\delta^{13} \mathrm{C}$ Within the (a) Upper Basalt Confined Aquifer System and (b) Rivers and Springs on the Hanford Site . . . . . . . 3.20

3.9 Relationship of (a) $\mathrm{HCO}_{3}^{-}$and ${ }^{13} \mathrm{C}$ and (b) ${ }^{14} \mathrm{C}$ and ${ }^{13} \mathrm{C}$ Within the Upper Basalt Confined Aquifer System and Rattlesnake Hills Springs Issuing from Basalt $\ldots \ldots \ldots . .21$

3.10 Histograms Showing the Frequency Distribution of ${ }^{3} \mathrm{H}$ Within the (a) Upper Basalt Confined Aquifer System and (b) Rivers and Springs on the Hanford Site 
3.11 Histograms Showing the Frequency Distribution of ${ }^{14} \mathrm{C}$ Within the (a) Upper Basalt Confined Aquifer System and (b) Rivers and Springs on the Hanford Site . . . . . . . 3.27

4.1 Comparison of Observed Hydraulic Heads for the Upper Basalt and Overlying Unconfined Aquifer Systems

\section{Tables}

2.1 Results of Linear Regression Analysis for Determination of Hydraulic Head Trends Within the Upper Basalt Confined Aquifer System at Selected Hanford Site Monitoring Wells

3.1 Summary of Major Inorganic Constituent Concentrations Within the Upper Basalt

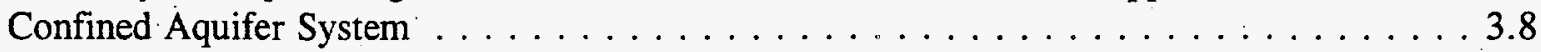

3.2 Summary of Trace-Element Concentrations Within the Upper Basalt Confined

3.3 Summary of Stable Isotope Contents Within the Upper Basalt Confined Aquifer System

3.4 Summary of Unstable Isotope Contents Within the Upper Basalt Confined Aquifer System

4.1 Presence of Hydrochemical Parameters Within Upper Basalt Wells, Indicating Aquifer Intercommunication and Groundwater Mixing with the Overlying Unconfined Aquifer in the Vicinity of the 200 East Area . 


\subsection{Introduction}

As part of the Hanford Site Ground-Water Surveillance Project, Flow System Characterization Task, Pacific Northwest Laboratory examines the potential for offsite migration of contamination within the upper basalt confined aquifer system for the U.S. Department of Energy (DOE). As part of this activity, groundwater samples were collected over the past 2 years from selected wells completed in the upper Saddle Mountains Basalt. The hydrochemical and isotopic information obtained from these groundwater samples provides hydrologic information concerning the aquifer-flow system. Ideally, when combined with other hydrologic property information, hydrochemical and isotopic data can be used to evaluate the origin and source of groundwater, areal groundwater-flow patterns, residence and groundwater travel time, rock/groundwater reactions, and aquifer intercommunication for the upper basalt confined aquifer system.

This report presents the first comprehensive Hanford Site-wide summary of hydrochemical properties for the upper basalt confined aquifer system. This report provides the hydrogeologic characteristics (Section 2.0) and hydrochemical properties (Section 3.0) for groundwater within this system. A detailed description of the range of the identified hydrochemical parameter subgroups (i.e., major inorganics, trace elements, isotopes) for groundwater in the upper basalt confined aquifer system is also presented in Section 3.0. Evidence that is indicative of aquifer contamination/aquifer intercommunication and an assessment of the potential for offsite migration of contaminants in groundwater within the upper basalt aquifer is provided in Section 4.0. The references cited throughout the report are given in Section 5.0. Tables that summarize groundwater sample analysis results for individual test interval/well sites are included in the Appendix. 


\subsection{Hydrogeologic Description}

The following hydrogeologic description is taken largely from Spane and Raymond (1993) and Spane and Vermeul (1994). As noted in those reports, the upper basalt confined aquifer system refers collectively to pervious basalt interflow contacts and intercalated sedimentary interbeds that occur within the upper Saddle Mountains Basalt. Confinement of this aquifer system is provided by silt and clay units within the overlying suprabasalt sediments (i.e., Ringold Formation) and dense, lowpermeability interior sections of the basalt flows (e.g., Elephant Mountain Member). Information presented previously by Gephart et al. (1979) and DOE $(1982,1988)$ indicates that confined aquifers within the Saddle Mountains Basalt commonly display a high degree of similarity with respect to hydrochemistry and hydraulic properties, with no obvious hydrostratigraphic divisions present. For the purpose of limiting the scope of this investigation, the lower boundary of the upper basalt confined aquifer system is arbitrarily placed immediately below the first laterally extensive hydrogeologic unit, which for the Hanford Site is the Rattlesnake Ridge interbed (Figure 2.1).

It should be noted that this aquifer system was previously referred to as the upper confined aquifer. However, in limited areas of the Hanford Site, units of the lower Ringold Formation (which stratigraphically overlies the Saddle Mountains Basalt) can also be locally confined. Where this hydrologic condition occurs, the lower Ringold units were grouped by sorne investigators with the underlying Saddle Mountains Basalt as part of the upper confined aquifer system. This report pertains solely to pervious hydrogeologic units within the upper Saddle Mountains Basalt that, for the purpose of avoiding confusion, are referred to collectively as the upper basalt confined aquifer system.

Within the Pasco Basin, the Rattlesnake Ridge interbed is the thickest and most widespread sedimentary unit that occurs intercalated within the upper Saddle Mountains Basalt. Stratigraphically, the interbed is assigned to the Ellensburg Formation and occurs at the boundary contact between the Elephant Mountain Member and the Pomona Member (see Figure 2.1). The interbed varies in thickness from 0 to $33 \mathrm{~m}$. Figure 2.2 is an isopach map that displays the thickness distribution for the Rattlesnake Ridge interbed within the Pasco Basin. As indicated in Figure 2.2, the interbed is absent primarily in the area to the west of the Hanford Site and within the Hanford Site in the western part of the Gable Mountain-Gable Butte structural area. The absence of the Rattlesnake Ridge interbed in the area immediately north of the 200 East Area is of particular hydrogeologic importance-the perimeter region of this area represents a region of potential interchange of groundwater between the upper confined and the overlying unconfined aquifer systems. 


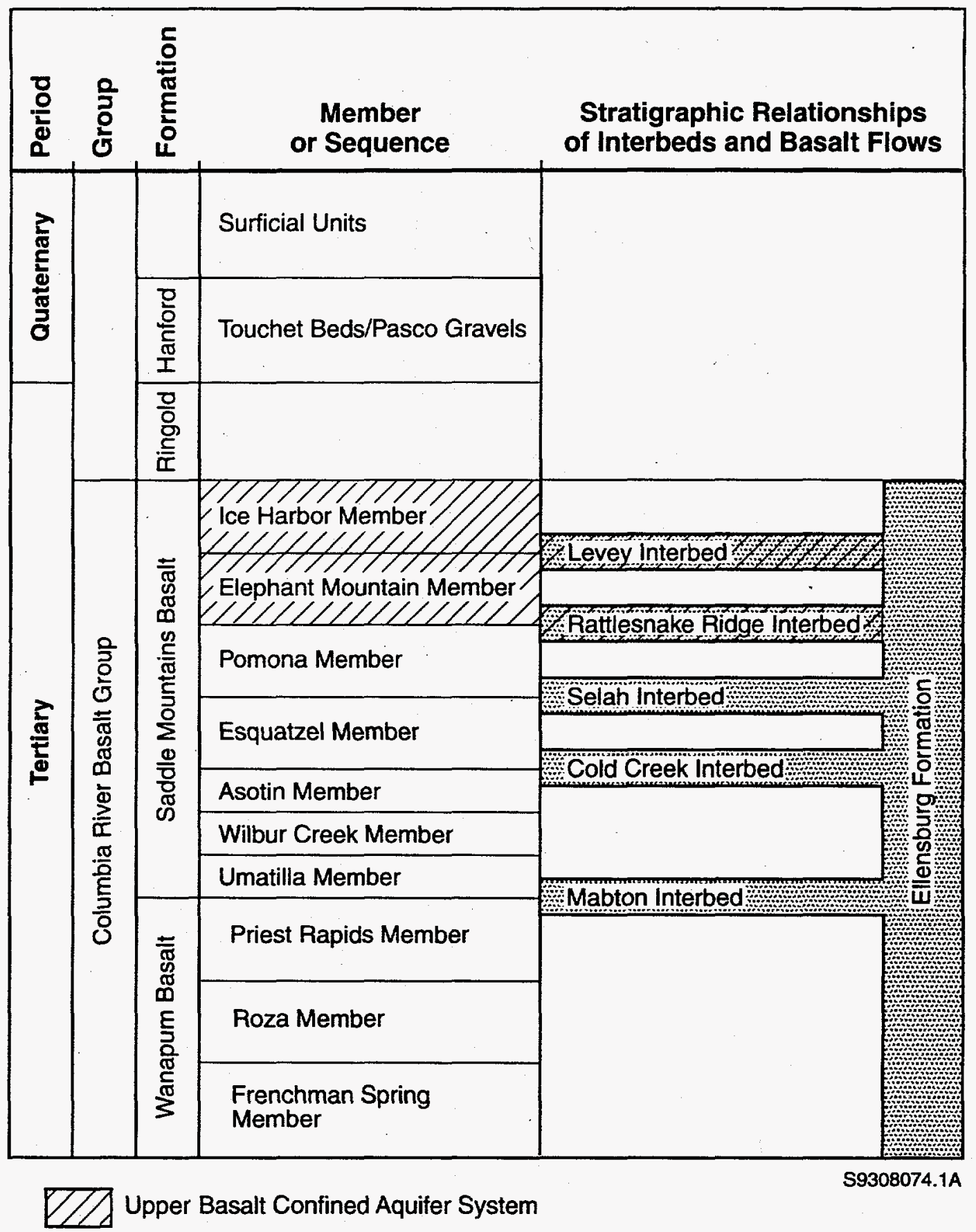

Figure 2.1. General Stratigraphic Relationships Within the Pasco Basin 


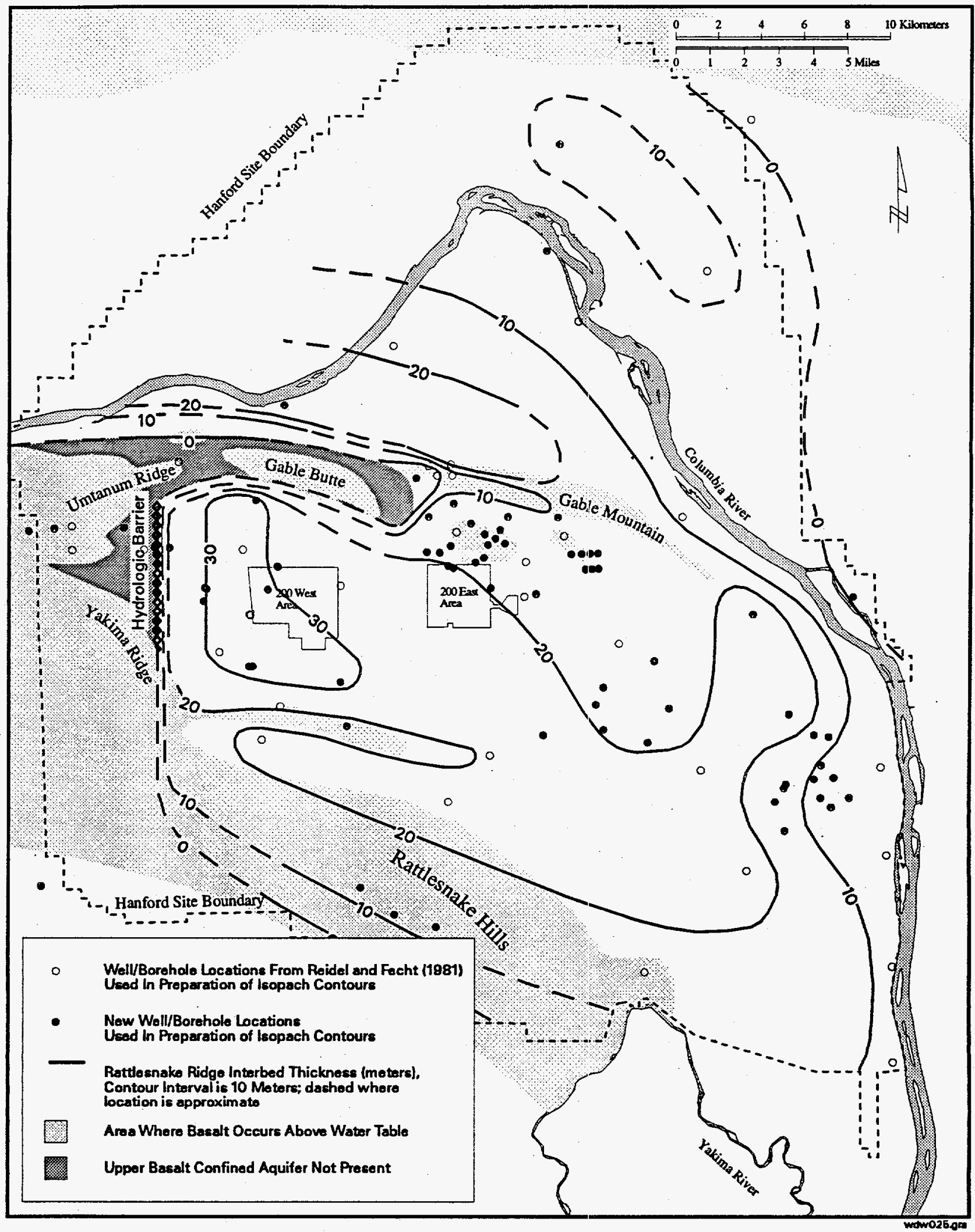

Figure 2.2. Isopach Map of the Rattlesnake Ridge Interbed on the Hanford Site 
Reidel and Fecht (1981) reported that, areally, the Rattlesnake Ridge interbed can be divided into three distinct facies, based on lithology and texture:

- First Facies occurs primarily in the Cold Creek syncline area and consists of three units: 1) a lower clay or tuffaceous sandstone; 2) a middle, micaceous-arkosic and/or tuffaceous sandstone; and 3) an upper, tuffaceous siltstone or tuffaceous sandstone.

- Second Facies occurs in areas where the unit is relatively thin and consists of a single, tuffaceous sandstone to siltstone unit.

- Third Facies is limited to the northwestern section of the Pasco Basin and is similar in lithology and texture to first facies but contains a conglomerate with plutonic and metamorphic clasts near its base.

Permeable sandstone units within the interbed are important hydrogeologically in the lateral transmission of groundwater. Because of its areal extent, hydraulic properties, and thickness, the Rattlesnake Ridge interbed represents the most important hydrogeologic unit within the upper basalt confined aquifer system for the potential offsite migration of contamination.

Other locally important hydrogeologic units within the upper basalt confined aquifer system include the overlying Levey interbed, which occurs along the southern boundary of the Hanford Site, and a pervious interflow contact between two Elephant Mountain Member flows (i.e., the Elephant Mountain and Ward Gap flows), which occurs in the eastern half of the Hanford Site. Although not as areally extensive as the underlying Rattlesnake Ridge interbed, where these units occur, their hydraulic characteristics warrant their inclusion in the upper basalt confined aquifer system.

Recharge to hydrogeologic units of the upper basalt confined aquifer system occurs through a number of natural processes and man-related activities. Direct recharge to the aquifer from precipitation and surface runoff occurs primarily in the Rattlesnake Hills region and the Saddle Mountains located along the southwestern and northern boundaries of the Hanford Site, respectively. Pervasive recharge from the overlying unconfined aquifer is also expected to occur within the western part of the Hanford Site, where a vertical downward head gradient is prevalent from the unconfined aquifer to the underlying upper basalt confined aquifer system. Past and current wastewater-disposal practices in proximity to the 200 East Area caused localized recharge to the upper basalt aquifer in this region. Of more significant areal impact are the effects of recharge from agricultural practices, primarily east of the Hanford Site. As will be discussed in Sections 2.1 and 2.2, the agricultural recharge occurring east of the Columbia River caused observed increases in hydraulic heads within the upper basalt confined aquifer system along the eastern boundary of the Hanford Site. 


\subsection{Hydraulic Head Conditions}

Figure 2.3 shows the potentiometric map and inferred lateral groundwater-flow pattern for the upper basalt aquifer, which was adapted from Spane and Raymond (1993). The potentiometric map was developed primarily from measurements obtained during March 1993. This time period was selected to minimize the effects of offsite irrigation activities and seasonal river-stage fluctuations of the Columbia River. Data obtained from active monitoring sites completed within the Rattlesnake Ridge interbed or upper Saddle Mountains Basalt were used directly in the construction of the potentiometric map. In areas where these data sources were not available, hydraulic head measurements obtained from inactive measurement sites (i.e., measurements obtained for an earlier time period) or for active wells completed in the top of the upper Saddle Mountains Basalt were utilized; however, with less reliance.

The potentiometric map and inferred groundwater-flow patterns developed for the upper basalt confined aquifer system are consistent with the areal head pattern indicated for the Mabton interbed, which is a deeper and more areally extensive confined aquifer underlying the Hanford Site (Spane 1987; DOE 1988). Salient features for the upper basalt aquifer system potentiometric map include:

- a prominent, broad recharge mound, extending northeastward from the Rattlesnake Hills-200 West Area

- a small recharge mound immediately east of the 200 East Area in the vicinity of B Pond

- a hydrologic barrier (i.e., groundwater-flow impediment) at the mouth of Cold Creek Valley

- the presence of a low hydraulic head (potential discharge) region in the Umtanum Ridge-Gable Mountain structural area

- a high hydraulic head region to the north and east of the Columbia River associated with recharge attributed to agricultural activities in these areas.

As stated in Spane and Raymond (1993), the broad recharge mound, extending from the Rattlesnake Hills-200 West Area, is believed attributable to a combination of 1) natural recharge that occurs within the Dry Creek drainage of the Rattlesnake Hills and 2) localized artificial recharge to the overlying unconfined aquifer (and, eventually, the upper basalt aquifer) from past wastewater disposal to $U$ Pond in the 200 West Area. The potential for possible hydrogeologic communication between the unconfined aquifer and hydrogeologic units of the underlying upper basalt aquifer in this area was noted in Spane et al. (1980). The lateral groundwater-flow pattern within the upper basalt confined 


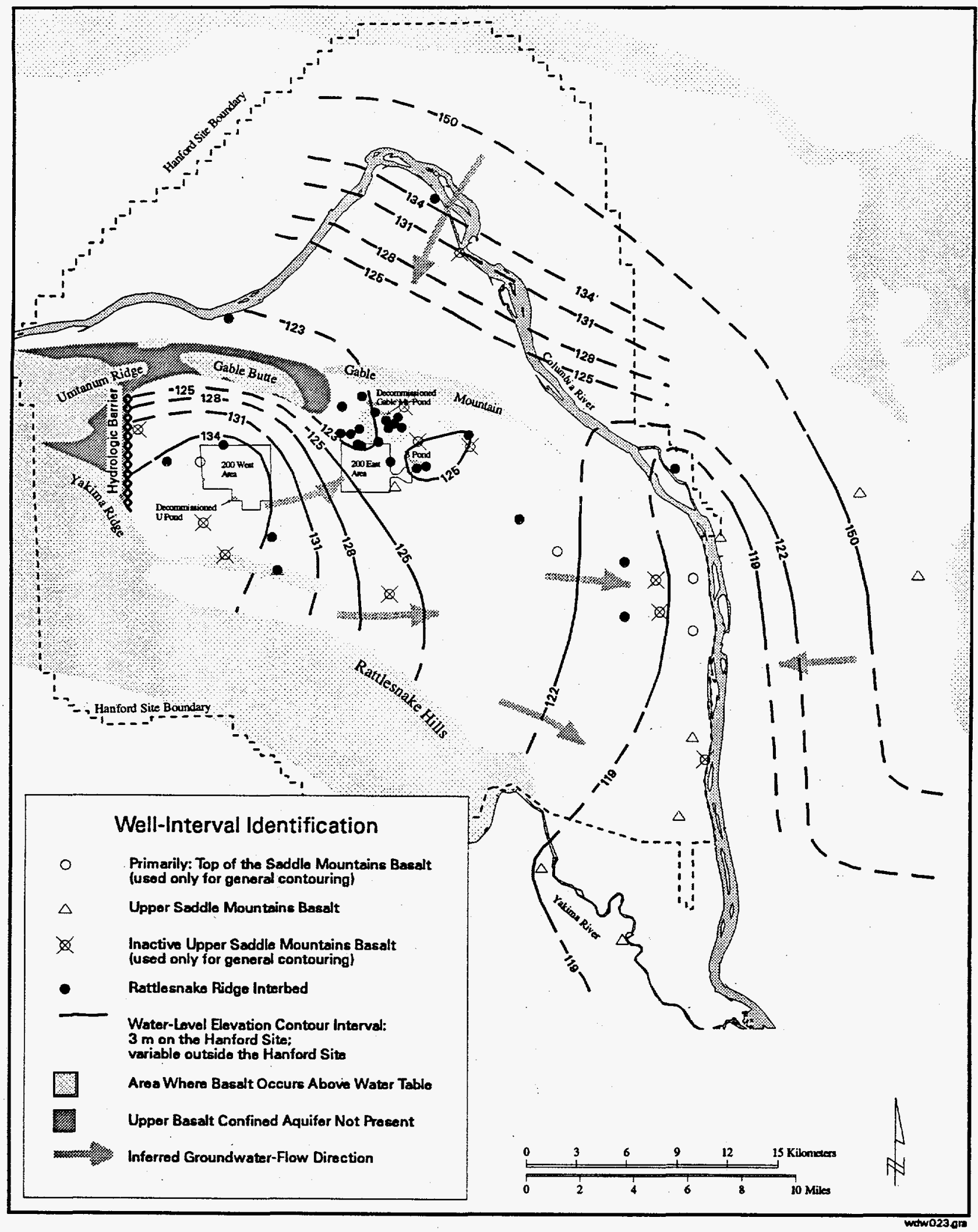

Figure 2.3. Potentiometric Map of the Upper Basalt Confined Aquifer System - March 1993 (adapted from Spane and Raymond 1993) 
aquifer system is strongly influenced by the presence of the groundwater mound and causes groundwater to flow radially away from this feature (primarily to the north and east) in the western section of the Hanford Site.

Figure 2.3 also indicates the influence of a small recharge mound immediately east of the 200 East Area in the vicinity of B Pond. The recharge mound is associated with local artificial recharge to the unconfined aquifer and underlying upper basalt confined aquifer system from wastewater-disposal activities at the $\mathrm{B}$ Pond complex. The presence of the recharge mound creates a downward hydraulic gradient from the unconfined aquifer to the underlying upper basalt confined aquifer system. This imposed hydrologic condition occurs in a region of the Hanford Site where a natural upward hydraulic gradient between the two aquifer systems would be expected (Section 4.0). The potential for possible hydrogeologic communication between the unconfined aquifer and the underlying upper basalt aquifer in this area was noted previously in Gephart et al. (1979) and Graham et al. (1984). The lateral groundwater-flow pattern within the upper basalt confined aquifer is also locally distorted by the presence of this groundwater mound and causes groundwater to flow radially away from this feature (primarily to the northwest and east) in this central region of the Hanford Site.

The presence of a hydrologic barrier (Cold Creek flow impediment) in the upper Cold Creek syncline was first postulated by Newcomb (1969), based on the significant lateral decrease in hydraulic head that occurred for irrigation wells completed in the upper Wanapum Basalt. The nature and geometry of this hydrogeologic feature are not completely understood. However, available well data suggest that the Cold Creek flow impediment interrupts the lateral hydraulic head gradient within the Saddle Mountains Basalt, Wanapum Basalt, and Grande Ronde Basalt and extends north-south from the Umtanum Ridge-Gable Mountain structure to Yakima Ridge (Spane 1987; DOE 1988). Identified hydrogeologic units of the upper basalt confined aquifer system (e.g., Rattlesnake Ridge interbed, Elephant Mountain Member interflow contact) are not present to the west of this feature. The potentiometric pattern shown suggests that the feature (possibly a fault) acts as an impermeable barrier, with no major groundwater transference occurring (either laterally or vertically).

The presence of a low hydraulic head (potential discharge) region in the Umtanum Ridge-Gable Mountain structural area is attributed to enhanced hydraulic intercommunication that occurs between the overlying and underlying aquifer systems. Increased hydraulic intercommunication is attributed to the absence of upper basalt hydrogeologic units, structural deformation, and presence of erosional. paleostream channels in this region (Gephart et al. 1979; Spane 1982; Graham et al. 1984; DOE 1988). Early et al. (1988) also reported that hydrochemical data and temporal hydrologic response information support the contention of significant hydraulic intercommunication and downward groundwater movement from the unconfined and upper basalt confined aquifers to underlying confined aquifers of the lower Saddle Mountains Basalt and Wanapum Basalt within this region. 
The high hydraulic head region to the north and east of the Columbia River is associated with recharge attributed to agricultural activities in these areas. The effects of recharge from irrigation and canal leakage (conveyance loss) east of the Columbia River have caused a significant increase in head and hydraulic gradients in this area. The potentiometric map pattern (see Figure 2.3) suggests that groundwater in the region northeast of Gable Mountain flows southwest and discharges primarily to adjacent aquifer systems in the Umtanum Ridge-Gable Mountain structural area. The Columbia River, therefore, does not represent a dominant line-sink discharge area for the upper basalt confined aquifer along this reach of the river. The temporal hydraulic head pattern for upper basalt monitoring wells located immediately west of the Columbia River exhibits a trend of increasing hydraulic head (Section 2.2), indicating that equilibrium conditions have not been reestablished for the level of recharge that is occurring to the east of the Columbia River. The trend of increasing hydraulic head has also been observed on the Hanford Site for deeper confined aquifer systems within the lower Saddle Mountains Basalt and Wanapum Basalt (e.g., Swanson and Leventhal 1984; DOE 1988).

\subsection{Flow System Dynamics}

As noted in Spane and Raymond (1993), flow system dynamic responses within the upper basalt confined aquifer system are a function of:

- proximity to sources of recharge and discharge

- magnitude and time distribution of recharge and discharge events

- presence of intervening geologic structures

- possible river and geologic outcrop relationships.

To provide information concerning recent temporal hydraulic head trends, water-level measurements obtained between January 1991 and June 1995 for 27 Hanford Site monitoring wells completed in the upper basalt aquifer were analyzed using linear regression analysis. Figure 2.4 shows the locations of the monitoring well sites. Table 2.1 summarizes the results of the regression analysis.

The temporal behavior of hydraulic heads within the upper basalt confined aquifer on the Hanford Site exhibited two distinct trend patterns. For most monitoring wells located along the eastern Hanford Site boundary, an increase in hydraulic head was observed over the $4 \frac{1}{2} 2$-year study period (January 1991 through June 1995). The annual head increase ranged between 0.02 and $0.36 \mathrm{~m} / \mathrm{yr}$, which is consistent with the steady, long-term increase reported by DOE $(1982,1988)$ for the underlying Saddle Mountains Basalt and Wanapum Basalt confined aquifers. The exception to this pattern is 


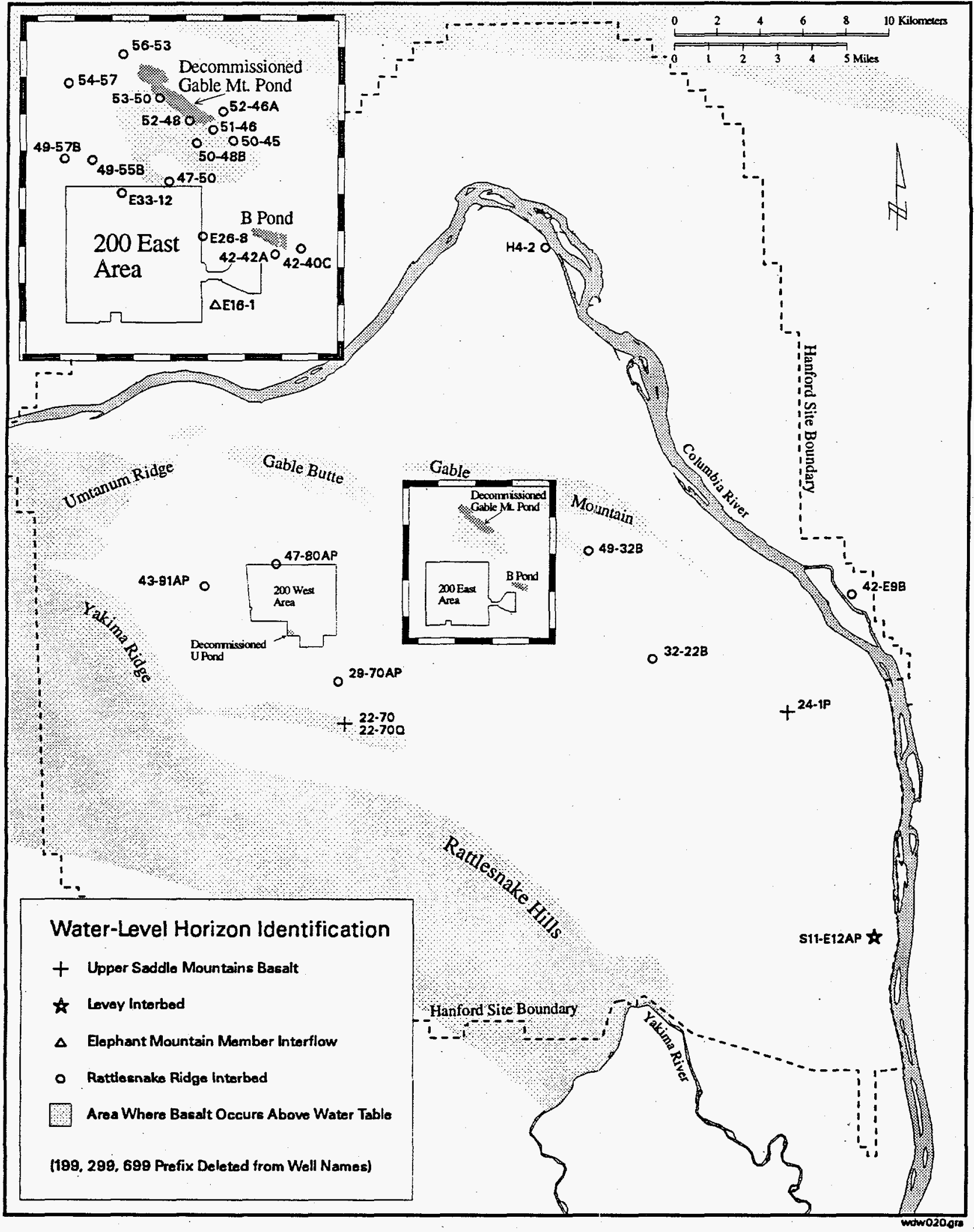

Figure 2.4. Location of Monitoring Wells Used for Evaluating Flow Dynamic Characteristics of the Upper Basalt Confined Aquifer System 
Table 2.1. Results of Linear Regression Analysis for Determination of Hydraulic Head Trends Within the Upper Basalt Confined Aquifer System at Selected Hanford Site Monitoring Wells

\begin{tabular}{|c|c|c|c|c|}
\hline Well & $\begin{array}{c}\text { Coefficient of } \\
\text { Determination } \\
r^{2}\end{array}$ & $\begin{array}{l}\text { Standard Error } \\
\text { of Estimate }\end{array}$ & $\begin{array}{c}\text { Linear Trend, } \\
\mathrm{m} / \mathrm{yr}\end{array}$ & Comments \\
\hline 199-H4-2 & 0.930 & 0.156 & +0.360 & \\
\hline 299-E16-1 & 0.785 & 0.090 & -0.141 & \\
\hline 299-E26-8 & 0.757 & 0.060 & -0.123 & \\
\hline 299-E33-12 & 0.919 & 0.091 & -0.226 & \\
\hline 699-S11-E12AP(a) & 0.979 & 0.038 & -0.243 & $6 / 92-3 / 95$ \\
\hline $699-22-70$ & 0.914 & 0.073 & -0.241 & \\
\hline $699-22-70 Q$ & 0.735 & 0.063 & -0.083 & \\
\hline 699-24-1P & 0.033 & 0.153 & +0.022 & \\
\hline 699-29-70AP & 0.933 & 0.051 & -0.156 & \\
\hline $699-32-22 B$ & 0.555 & 0.126 & +0.122 & \\
\hline 699-42-E9B & 0.022 & 0.205 & +0.027 & Affected by river \\
\hline $699-42-40 \mathrm{C}$ & $\begin{array}{l}0.898 \\
0.051 \\
\end{array}$ & $\begin{array}{l}0.055 \\
0.112 \\
\end{array}$ & $\begin{array}{l}-0.215 \\
+0.054 \\
\end{array}$ & $\begin{array}{l}3 / 91-10 / 93 \\
12 / 93-6 / 95 \\
\end{array}$ \\
\hline $699-42-42 A$ & $\begin{array}{l}0.871 \\
0.988\end{array}$ & $\begin{array}{l}0.064 \\
0.006\end{array}$ & $\begin{array}{l}-0.199 \\
+0.059\end{array}$ & $\begin{array}{c}3 / 91-12 / 93 \\
3 / 94-6 / 95\end{array}$ \\
\hline 699-43-91AP & 0.906 & 0.064 & -0.170 & \\
\hline $699-47-50$ & 0.908 & 0.049 & -0.146 & $1 / 92-6 / 95$ \\
\hline 699-47-80AP & 0.972 & 0.038 & -0.203 & \\
\hline 699-49-32B & 0.863 & 0.051 & -0.081 & \\
\hline 699-49-55B & 0.881 & 0.103 & -0.237 & \\
\hline 699-49-57B & 0.949 & 0.049 & -0.181 & \\
\hline $699-50-45$ & 0.953 & 0.037 & -0.128 & \\
\hline $699-50-48 B$ & 0.956 & 0.042 & -0.153 & \\
\hline $699-51-46$ & 0.962 & 0.035 & -0.137 & \\
\hline $699-52-46 \mathrm{~A}$ & 0.957 & 0.033 & -0.118 & \\
\hline $699-52-48$ & 0.966 & 0.035 & -0.143 & \\
\hline 699-53-50 & 0.943 & 0.051 & -0.165 & \\
\hline $699-54-57$ & 0.881 & 0.104 & -0.225 & \\
\hline $699-56-53$ & 0.947 & 0.057 & -0.183 & \\
\hline
\end{tabular}


well 699-S11-E12AP, which recorded a decreasing pattern of $-0.243 \mathrm{~m} / \mathrm{yr}$. Well $699-\mathrm{S} 11-\mathrm{E} 12 \mathrm{AP}$ is completed in the Levey interbed, which is of limited lateral extent and, therefore, may not be directly comparable with results obtained from wells monitoring the underlying, more areally extensive Rattlesnake Ridge interbed or Elephant Mountain Member.

The increasing head pattern for this region is attributed to irrigation activities within the area east of the Columbia River. The fact that hydraulic head values continue to increase in this region indicates that equilibrium conditions have not been reestablished for the level of recharge from irrigation occurring in this area and also support the observation noted in Section 2.1 that the Columbia River does not form a dominant line-sink discharge area for groundwater within the upper basalt confined aquifer system along its entire reach within the Pasco Basin.

For monitoring wells not located along the eastern Hanford Site boundary (i.e., in the vicinity of the Columbia River), a decrease in hydraulic head was observed over the same $4 \frac{1}{2} 2$-year study period. The head decrease ranged between 0.08 and $0.24 \mathrm{~m} / \mathrm{yr}$, with the greatest declines occurring in the vicinity of the 200 Areas. The declining head patterns were, in most cases, extremely linear in appearance, with no recognizable natural seasonal components evident. The decline in hydraulic head in this area of the Hanford Site is similar to the pattern noted earlier in Spane and Raymond (1993) for the upper basalt confined aquifer system. The declining head pattern for the upper basalt aquifer is similar to that reported for the overlying unconfined aquifer, which is attributed to the continuing decline in wastewater discharges to the unconfined aquifer in the 200 Areas (Newcomer 1990; Dresel et al. 1994).

\subsection{Hydraulic Properties}

Hanford Site test data from 35 single-well-test intervals within the upper basalt confined aquifer system were reanalyzed and reported in Spane and Vermeul (1994). The principal hydrogeologic unit distribution for test intervals evaluated are, from most to least, Rattlesnake Ridge interbed $(n=22)$, Elephant Mountain Member interflow contacts $(n=7)$, and Levey interbed $(n=2)$. In addition, four of the test intervals have composite hydrogeologic unit completions. Hydraulic test data available for the test intervals are primarily limited to slug tests $(n=18)$ and constant-rate discharge tests $(n=35)$. Only 18 of the 35 test intervals have both slug and constant-rate discharge test data.

Figure 2.5 shows the comparison of transmissivity estimates obtained for the 18 test intervals having both slug and constant-rate pumping test analysis results. As indicated in the figure, most transmissivity estimates obtained from slug and constant-rate pumping tests correspond within a factor of three. This level of correspondence is similar to previous slug test assessments reported in Papadopulos et al. (1973) and van der Kamp (1976). 
Figure 2.6 shows a comparison of transmissivity values for individual hydrogeologic units comprising the upper basalt confined aquifer system. Results of the test reanalyses indicate a similar range for transmissivity values for the various hydrogeologic units. Approximately $90 \%$ of the calculated transmissivity values for the upper basalt confined aquifer hydrogeologic units occurs within the range of $10^{\circ}$ to $10^{2} \mathrm{~m}^{2} / \mathrm{d}$, with $65 \%$ of the calculated values occurring between $10^{1}$ to $10^{2} \mathrm{~m}^{2} / \mathrm{d}$. These summary findings are consistent with the general range for basalt interflow contact zones and sedimentary interbeds within the Saddle Mountains Basalt reported in Gephart et al. (1979), Strait and Mercer (1987), and DOE (1988). Of particular hydrologic interest is that, for approximately $20 \%$ of the upper basalt interval tests presented in Spane $(1981,1992)$ and Spane and Vermeul (1994), leaky confined aquifer conditions and/or presence of a recharge boundary are indicated. This hydrogeologic information is of significance with respect to aquifer intercommunication, which is discussed in Section 4.0. The lack of a uniform spatial distribution of test data, however, precludes any definitive areal pattern interpretations for leaky aquifer conditions or recharge boundaries within the upper basalt confined aquifer system on the Hanford Site. 


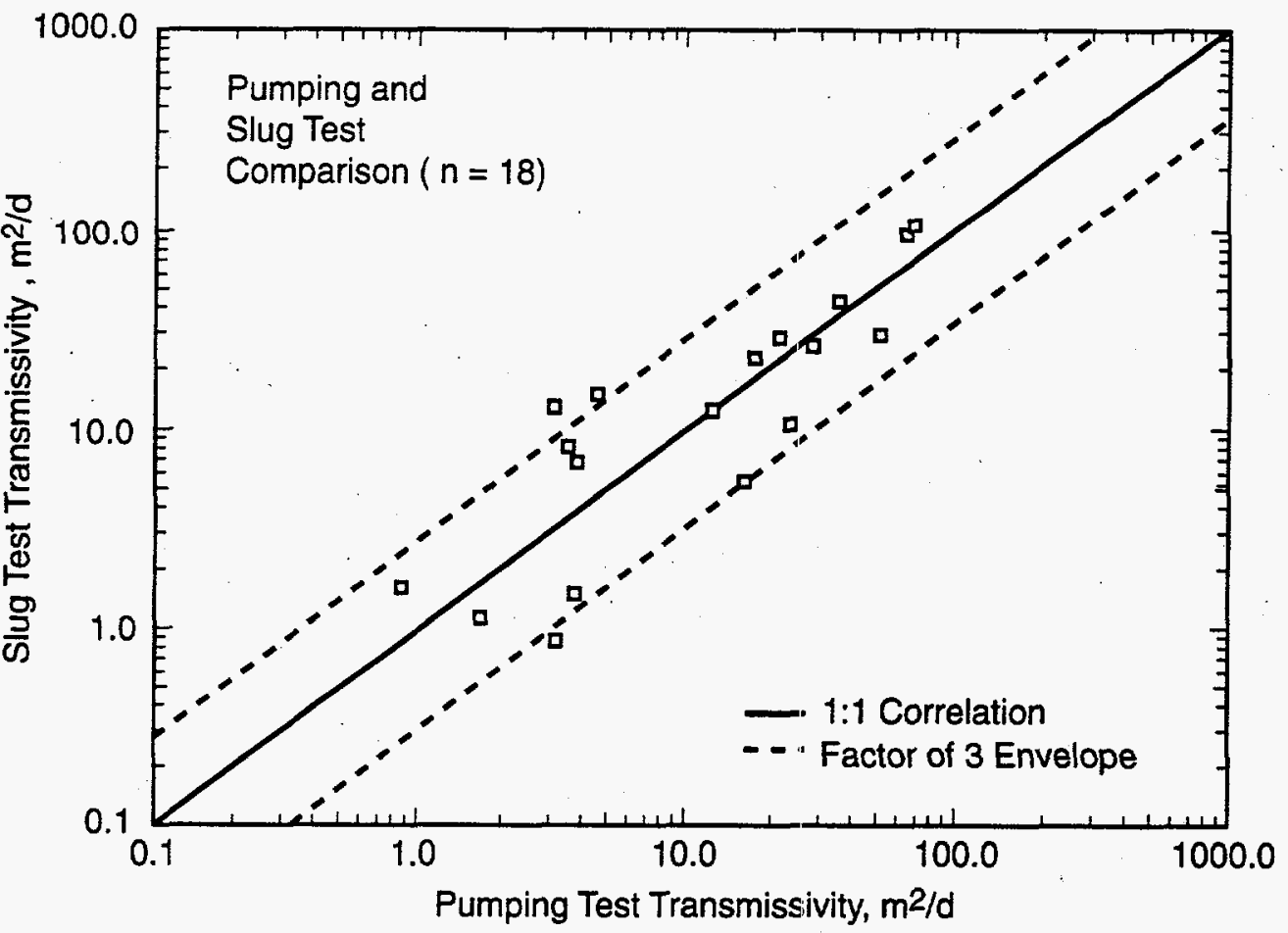

$\$ 9409020.3 a$

Figure 2.5. Comparison of Slug and Constant-Rate Pumping Test Analysis Results for Upper Basalt Confined Aquifer System Test Intervals (adapted from Spane and Vermeul 1994)

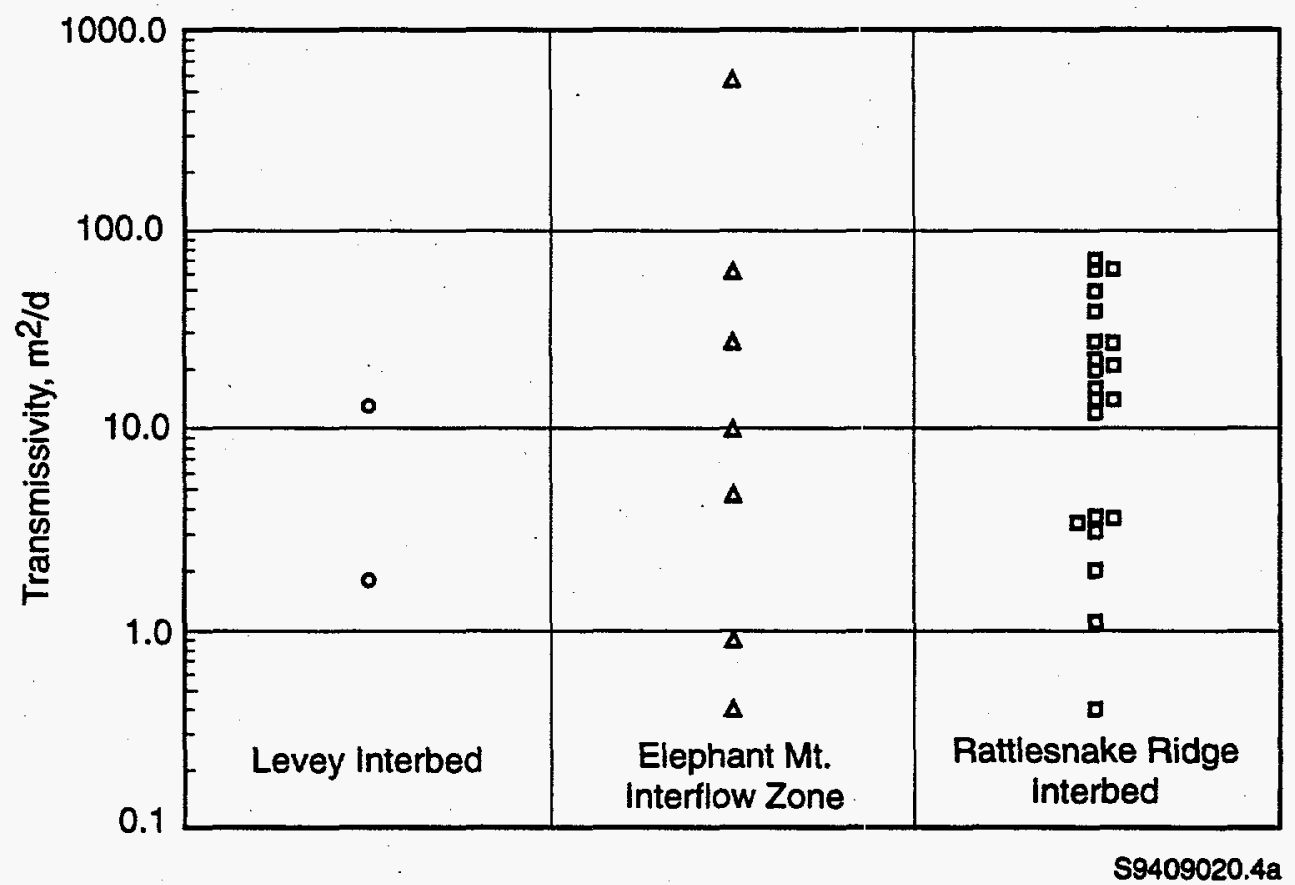

Figure 2.6. Distribution of Transmissivity Estimates for Individual Hydrogeologic Units Within the Upper Basalt Confined Aquifer System (adapted from Spane and Vermeul 1994) 


\subsection{Hydrochemistry}

Hydrochemical data from 33 Hanford Site well-test intervals and 4 offsite wells completed within the upper basalt confined aquifer system were selected for evaluation. The number of available hydrochemical data sets by principal hydrogeologic unit is, from most to least, Rattlesnake Ridge interbed $(n=24)$, Elephant Mountain Member interflow contacts $(n=5)$, and Levey interbed $(n=2)$. In addition, six of the sampled well sites have composite hydrogeologic unit completions within the upper Saddle Mountains Basalt, with no assigned principal hydrogeologic unit identification.

The hydrochemical data evaluated in this report were obtained from a variety of past and current Hanford Site programs. Identified programs and contractors that contributed test data reviewed in this report include the following:

- Long-Term Transuranic Defense Waste - Offsite Migration Program (Rockwell Hanford Operations)

- Basalt Waste Isolation Project (Rockwell Hanford Operations/Westinghouse Hanford Company)

- Ground-Water Surveillance Project, Hanford Site Flow System Characterization Task (Pacific Northwest Laboratory)

- Various Hanford Site CERCLA (Comprehensive Environmental Response, Compensation, and Liability Act of 1980) and RCRA (Resource Conservation and Recovery Act of 1976) operable unit investigations (Westinghouse Hanford Company).

Figure 3.1 shows the well-site locations of the upper basalt confined aquifer system sample intervals examined as part of this report. Hydrochemical and isotopic data available for the individual test-well sites are provided in the Appendix. Pertinent information concerning the test wells (e.g., well completions, principal hydrogeologic units sampled from) is also presented in Spane and Raymond (1993) and Spane and Vermeul (1994).

Hydrochemical data presented in the Appendix and discussed in this report are from selected upper basalt sampling horizons for which complete analyses of major inorganic constituents are available from the Hanford Environmental Information System (HEIS). Although numerous partial chemical analyses are available for many of the selected upper basalt aquifer sample locations, the quality of much of the historical data is inconsistent with more recent data. This is attributed to the improvement in laboratory analytical techniques, sample tracking, and data-management practices that occurred over time. Because it is impractical to evaluate the validity of all available analyses for upper basalt 


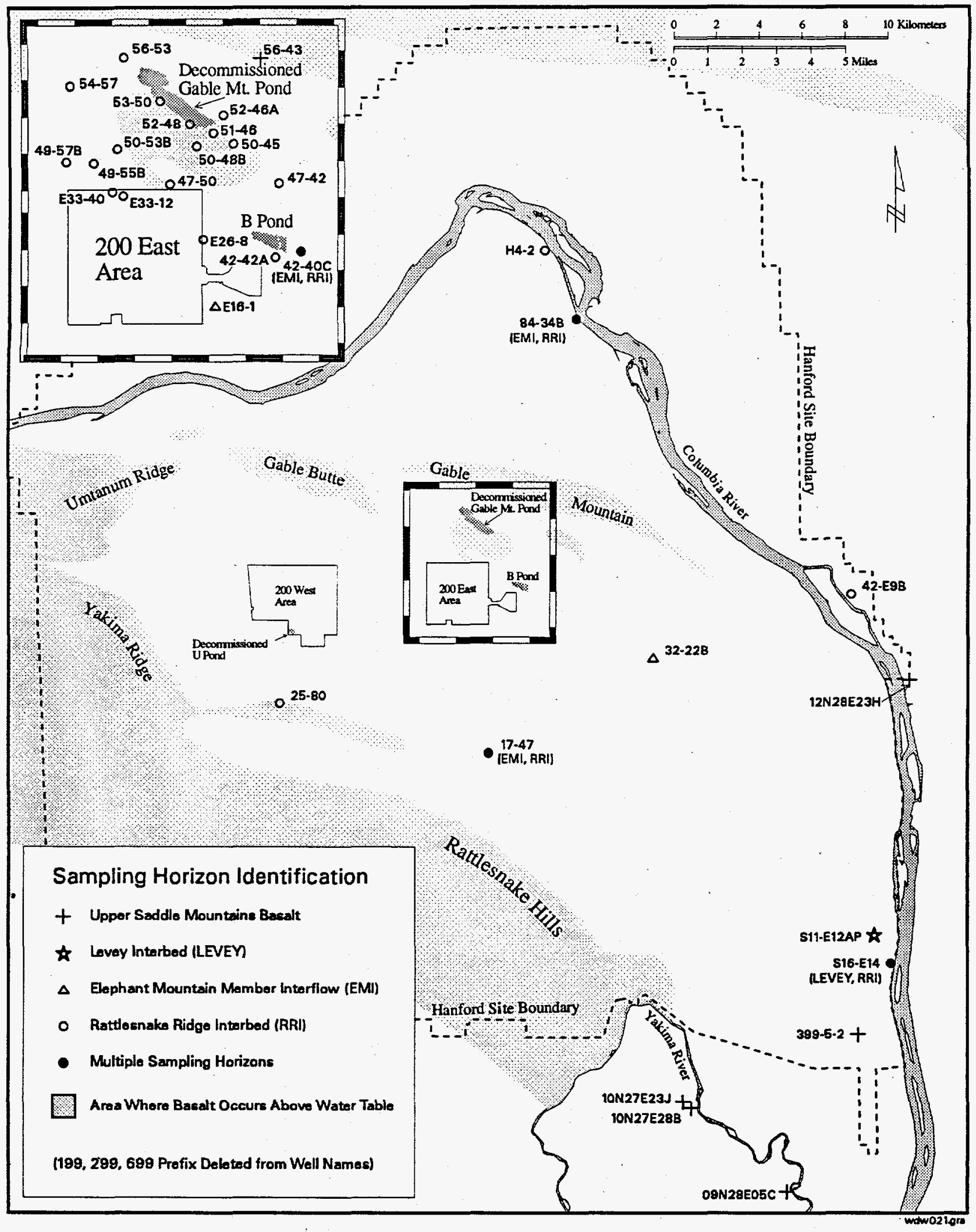

Figure 3.1. Location of Upper Basalt Confined Aquifer System Groundwater Well-Sampling Sites 
groundwaters and for well locations having multiple complete chemical analyses, the more recent sample analysis results were utilized in this report. In addition, only samples having a major ionic summation balance ([ $\Sigma$ cations $-\Sigma$ anions $] /[\Sigma$ cations $+\Sigma$ anions]; i.e., expressed in milliequivalents/liter) within $\pm 5 \%$ were used in the hydrochemical characterization evaluation. For samples collected from boreholes and wells constructed as part of the Basalt Waste Isolation Project during the 1980 s, the elevated drilling fluid tracer indicators (e.g., organic carbon and tritium $\left[{ }^{3} \mathrm{H}\right]$ ), as suggested in Graham (1984) and Early et al. (1986), were used as a basis for rejection from the sample dataset. Based on these sample-screening criteria, well 699-31-84A was omitted because of the presence of elevated drilling fluid components. In addition, several well-sample analyses were rejected as being anomalous and are believed to be reflective of poor well completions (i.e., wells 199-B3-2P, 699-54-45B, and 699-13-1C).

\subsection{Hydrochemical Evolutionary Patterns}

Chemical constituents dissolved within groundwater of the upper basalt confined aquifer system reflect the evolution and interaction of various processes within the flow system (e.g., nature and source of recharge water, water-rock mineral reactions, residence time for geochemical processes to take place, length of groundwater flow path, and mixing of groundwaters from adjacent hydrogeologic units). Gephart et al. (1979) and DOE (1988) stated that groundwater within the Columbia River basalt aquifer systems and associated volcaniclastic intercalated sediments located in precipitation-derived recharge areas is characterized by a predominant calcium, magnesium-bicarbonate $(\mathrm{Ca}, \mathrm{Mg}-\mathrm{HCO}$ ) chemical water type. As noted by DOE (1988), Steinkampf (1989), and Whiteman et al. (1994), the predominant $\mathrm{Ca}, \mathrm{Mg}-\mathrm{HCO}_{3}$ chemical composition of the groundwater reflects dissolution of rock minerals by recharging waters through carbonic acid reactions and silicate hydrolysis. Water entering the upper basalt aquifer system directly from precipitation is extremely dilute and possesses a low $\mathrm{pH}$. Entering the soil zone, additional carbon dioxide is dissolved in the recharge water, adding to its reaction capacity (i.e., its capacity to react and dissolve mineral phases comprising the aquifer framework). Whiteman et al. (1994) noted that in recharge areas devoid of a well-developed soil horizon or vegetative cover and parts of the groundwater-flow system where little or no oxygen is available, carbonic acid is not generated. In such areas, silicate hydrolysis is the dominant dissolution mechanism.

With increased aquifer-residence time and more chemical interaction with the aquifer matrix, the cation composition of the groundwater evolves to a predominant sodium (Na) character. The evolution 
of the upper basalt aquifer groundwaters to a sodium-bicarbonate $\left(\mathrm{Na}-\mathrm{HCO}_{3}\right)$ chemical water type is attributed by Gephart et al. (1979) and Whiteman et al. (1994) to a number of geochemical processes, including:

- calcite $\left(\mathrm{CaCO}_{3}\right)$ precipitation/mineral equilibria

- cation-exchange processes

- Na increases from volcanic glass hydrolysis/dissolution reactions.

A detailed discussion of these geochemical processes, together with an evaluation of possible reaction path models in controlling the evolutionary composition of basalt aquifer groundwaters is presented in DOE (1988).

The hydrochemical evolution of groundwaters within the upper basalt aquifer from a predominantly $\mathrm{Ca}$ to $\mathrm{Na}$ cation composition is illustrated in the trilinear diagram shown in Figure 3.2. For comparison purposes, the composite plot of 12 springs issuing from the Saddle Mountains Basalt within the Rattlesnake Hills (a known local natural recharge area for the upper basalt confined aquifer system) is also shown in Figure 3.2. As indicated in the lower left cation triangle and central composite diamond sections of the figure, hydrochemical evolution trends are clearly indicated from $\mathrm{Ca}, \mathrm{Mg}-\mathrm{HCO}_{3}$ groundwater types, located near areas of recharge, to $\mathrm{Na}-\mathrm{HCO}_{3}$ hydrochemical types for more evolved waters, which are commonly located near areas of discharge.

The hydrochemical evolutionary pattern is shown by areal changes in the shape and size of the Stiff diagram symbols for upper basalt groundwaters beneath the Hanford Site. As indicated in Figure 3.3, samples located along the eastern margin of the Hanford Site are characterized by Stiff diagram shapes indicative of an $\mathrm{Na}-\mathrm{HCO}_{3}$ composition. When compared with areal groundwater-flow patterns for the upper basalt system shown in Figure 2.3, the hydrochemical patterns shown in Figure 3.3 are consistent with the conceptual model of greater groundwater-residence time and -flow distance from known recharge areas. In contrast, the predominant $\mathrm{Ca}, \mathrm{Mg}-\mathrm{HCO}_{3}$ hydrochemical water type in the Gable Mountain-200 East Area (see insert on Figure 3.3) is indicative of recharge from the overlying unconfined aquifer system. As discussed in Section 2.1, this area was identified on the basis of available hydrogeologic and hydraulic head information as a region of intercommunication between the two aquifer systems.

It should be noted that the previous discussions concerning hydrochemical patterns pertain to data primarily obtained for the Rattlesnake Ridge interbed unit of the upper basalt confined aquifer system. While some small variation in hydrochemical characteristics might be expected between the Elephant 


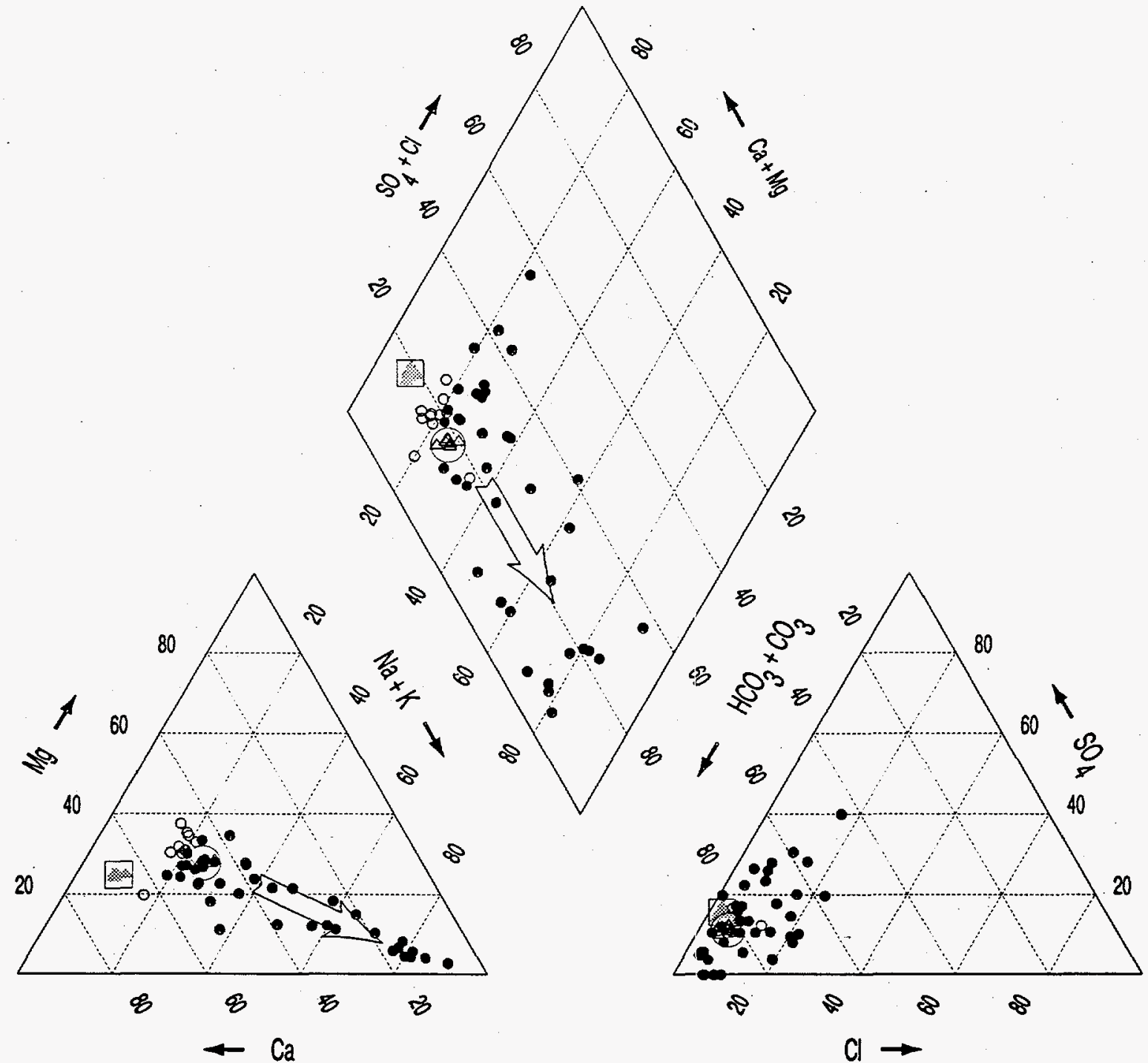

* Individual Columbia River Waters

- Individual Rattlesnake Hills Spring Waters

Combined Columbia River Waters

- Upper Basalt Aquifer Water from Wells

$\Delta$ Individual Yakima River Waters

Combined Yakima River Waters

Hydrochemical Evolutionary Path

Figure 3.2. Trilinear Diagram, Showing Hydrochemical Evolution of Groundwater Within the Upper Basalt Confined Aquifer System 


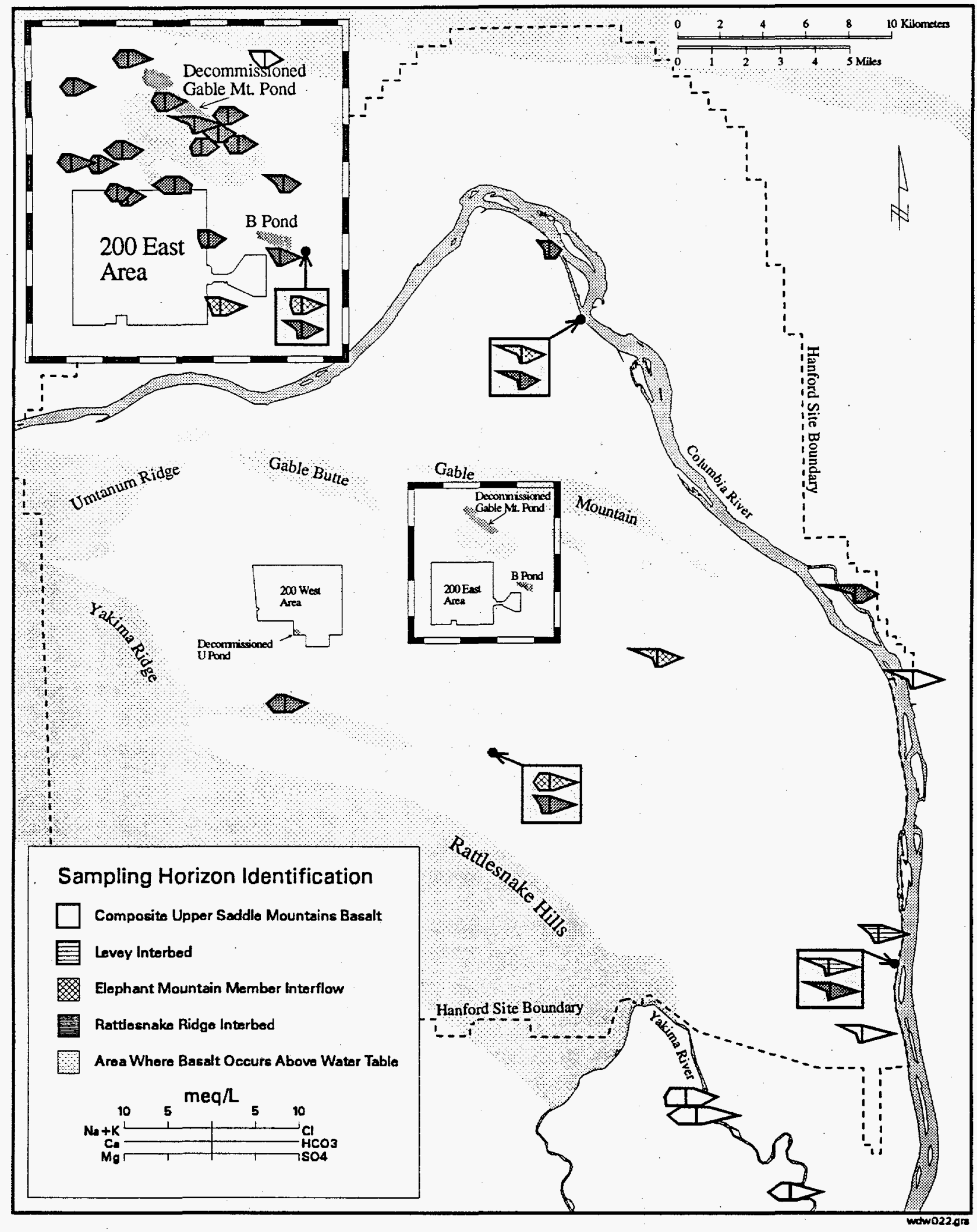

Figure 3.3. Hydrochemical Facies Stiff Diagram Map for Groundwater Within the Upper Basalt Confined Aquifer System 
Mountain Member interflow and Rattlesnake Ridge interbed (especially in less-chemically evolved waters near recharge areas), the same cation evolutionary pattern (i.e., evolving from predominantly Ca to $\mathrm{Na}$ ) is reported in Gephart et al. (1979), DOE (1988), and Whiteman et al. (1994) for groundwaters within basalt interflow zones. The similarity in hydrochemical composition is attributed, in part, to the fact that the sedimentary interbeds are comprised primarily of deposits derived from the erosion and weathering of the surrounding basalt surface at the time of the sediment deposition. The greater abundance of volcanic glass and presence of tuffaceous materials within the interbeds may contribute, however, to an initially greater $\mathrm{Na}$ content in the interbed groundwaters, in comparison to basalt interflow zones near recharge areas.

Offsite groundwater samples collected from the shallow upper basalt system immediately south of the Yakima River also exhibit a distinct $\mathrm{Ca}, \mathrm{Mg}-\mathrm{HCO}_{3}$ water type, typical of less-chemically evolved groundwater. The groundwater for these samples also contains elevated concentrations of sulfate $\left(\mathrm{SO}_{4}^{-2}\right)$, chloride $\left(\mathrm{Cl}^{-}\right)$, and nitrate $\left(\mathrm{NO}_{3}^{-}\right)$, which, as reported in Newcomb (1972), Gephart et al. (1979), and Whiteman et al. (1994), occur commonly within the surrounding region for shallow basalt aquifer wells that are affected by artificial recharge associated with agricultural activities.

\subsection{Major Inorganic Constituents}

Table 3.1 shows the range, median, and mean values for major inorganic constituents within upper basalt aquifer groundwaters listed in the Appendix. Upper basalt groundwaters can be characterized as moderately dilute solutions, having total dissolved solids contents generally $\leq 250 \mathrm{mg} / \mathrm{L}$. Principal inorganic constituents indicated in Table 3.1 include $\mathrm{Ca}^{+2}, \mathrm{Na}^{+-}, \mathrm{Mg}^{+2}, \mathrm{HCO}_{3}^{-}, \mathrm{SO}_{4}^{-2}$, and silica $\left(\mathrm{SiO}_{2}\right)$. Considerable variability in the range of major inorganic concentrations is exhibited. This is largely attributed to the source and distance to locations of recharge (natural versus artificial), degree of aquifer intercommunication, and hydrochemical evolutionary patterns within the upper basalt aquifer. The range, median, and mean values of major inorganic constituents listed in Table 3.1 are consistent with values previously reported for Saddle Mountains Basalt groundwaters in Gephart et al. (1979), Spane et al. (1982), and DOE (1988).

Of particular interest is the variation of $\mathrm{NO}_{3}^{-}$content within the upper basalt aquifer. Because $\mathrm{NO}_{3}^{-}$ was a common constituent in many of the waste streams discharged to the soil column at the Hanford Site and is mobile in groundwater, it has been routinely used to delineate the extent of contamination within the overlying unconfined aquifer (e.g., Dresel et al. 1994). The current extent of the primary $\mathrm{NO}_{3}^{-}$contaminant plume within the unconfined aquifer is shown in Dresel et al. (1994) to emanate from wastewater-disposal areas within the 200 East Area and occupies a large portion of the eastern region of the Hanford Site. Other less-extensive $\mathrm{NO}_{3}^{-}$contaminant plumes are associated with known wastewater-discharge locations in the 200 West Area and various facilities in the 100 Areas. 
Table 3.1. Summary of Major Inorganic Constituent Concentrations Within the Upper Basalt Confined Aquifer System

\begin{tabular}{|c|c|c|c|}
\hline Constituent & $\begin{array}{c}\text { Range, } \mathrm{mg} / \mathrm{L} \\
\text { (Number of Samples) }\end{array}$ & Median, mg/L & $\begin{array}{c}\text { Mean, } \mathrm{mg} / \mathrm{L} \\
\pm \text { Standard Deviation }\end{array}$ \\
\hline $\mathrm{HCO}_{3}^{-}$ & $85.4-292.6(37)$ & 128.0 & $132.4 \pm 33.8$ \\
\hline $\mathrm{Cl}^{-}$ & $1.0-50.0(37)$ & 9.0 & $13.3 \pm 10.2$ \\
\hline $\mathrm{F}^{-}$ & $0.3-1.9(37)$ & 0.7 & $0.8 \pm 0.4$ \\
\hline $\mathrm{SO}_{4}^{-2}$ & $0.5-88.0(35)$ & 23.5 & $25.8 \pm 19.5$ \\
\hline $\mathrm{NO}_{3}^{-}$ & $<0.2-46.0(27)$ & 1.0 & $4.3 \pm 8.9$ \\
\hline $\mathrm{Na}^{+}$ & $10.0-104.0(37)$ & 26.0 & $33.2 \pm 18.7$ \\
\hline $\mathrm{K}^{+}$ & $3.1-14.0(37)$ & 8.7 & $8.4 \pm 2.5$ \\
\hline $\mathrm{Ca}^{+2}$ & $5.9-66.0(37)$ & 26.6 & $26.0 \pm 14.0$ \\
\hline $\mathrm{Mg}^{+2}$ & $1.8-27.0(37)$ & 8.4 & $8.6 \pm 5.9$ \\
\hline $\mathrm{SiO}_{2}$ & $40.6-79.2(29)$ & 28.0 & $29.1 \pm 5.9$ \\
\hline $\begin{array}{l}\text { Total dissolved solids } \\
\text { (sum) }\end{array}$ & $166-468(37)$ & 241 & $250.4 \pm 58.8$ \\
\hline
\end{tabular}

The presence of elevated $\mathrm{NO}_{3}^{-}$concentrations within hydrogeologic units of the upper basalt confined aquifer system has been utilized by previous investigators (Gephart et al. 1979; Spane et al. 1980; Graham et al. 1984) as a hydrochemical indicator of aquifer intercommunication and/or groundwater mixing with the overlying contaminated unconfined aquifer. An examination of $\mathrm{NO}_{3}^{-}$ content for individual upper basalt wells listed in the Appendix indicates that the majority of onsite wells (i.e., $>92 \%$ ) exhibiting $\mathrm{NO}_{3}^{-}$concentrations $>1.0 \mathrm{mg} / \mathrm{L}$ are located in the vicinity of the 200 East Area and Gable Mountain. As noted previously, this is an area of known intercommunication between the unconfined and upper basalt confined aquifer systems. Additional discussion and hydrochemical evidence for aquifer intercommunication and groundwater mixing in this area are presented in Sections 4.1 and 4.2.

\subsection{Trace Elements}

Table 3.2 shows the range and median values for trace-element constituents within upper basalt aquifer groundwaters listed in the Appendix. For many analyses, individual trace-element constituents were at or below laboratory detection levels. This makes calculating mean concentrations impractical 
Table 3.2. Summary of Trace-Element Concentrations Within the Upper Basalt Confined Aquifer System

\begin{tabular}{||l|c|c||}
\hline \multicolumn{1}{|c|}{ Constituent } & $\begin{array}{c}\text { Range, mg/L } \\
\text { (Number of Samples) }\end{array}$ & Median, mg/L \\
\hline $\mathrm{Ag}$ & $<0.006-0.010(28)$ & $<0.006$ \\
\hline $\mathrm{Al}$ & $<0.031-0.140(35)$ & $<0.031$ \\
\hline $\mathrm{B}$ & $<0.005-0.150(12)$ & 0.025 \\
\hline $\mathrm{Ba}$ & $<0.001-0.146(37)$ & 0.061 \\
\hline $\mathrm{Cd}$ & $<0.003-0.007(28)$ & $<0.003$ \\
\hline $\mathrm{Co}$ & $<0.007-0.009(36)$ & $<0.007$ \\
\hline $\mathrm{Cr}$ & $<0.011-0.170(36)$ & $<0.011$ \\
\hline $\mathrm{Cu}$ & $<0.004-0.024(36)$ & $<0.004$ \\
\hline $\mathrm{Fe}$ & $<0.018-2.720(37)$ & 0.055 \\
\hline $\mathrm{Mn}$ & $<0.001-0.173(37)$ & 0.008 \\
\hline $\mathrm{Mo}$ & $<0.008-0.170(11)$ & $<0.008$ \\
\hline $\mathrm{Ni}$ & $<0.016-0.120(36)$ & $<0.016$ \\
\hline $\mathrm{Sb}$ & $<0.005-0.060(27)$ & $<0.062$ \\
\hline $\mathrm{Sr}$ & $<0.020-0.160(14)$ & 0.024 \\
\hline $\mathrm{Zn}$ & $<0.006-0.210(37)$ & 0.010 \\
\hline
\end{tabular}

for trace-element constituents. Principal trace elements indicated in the Appendix and Table 3.2 include aluminum $(\mathrm{Al})$, barium $(\mathrm{Ba})$, boron $(\mathrm{B})$, iron $(\mathrm{Fe})$, manganese $(\mathrm{Mn})$, strontium $(\mathrm{Sr})$, and zinc (Zn). The trace-element concentration information listed in Table 3.2 is consistent with values listed in Gephart et al. (1979), Spane et al. (1982), and Whiteman et al. (1994) for basalt groundwaters within the region.

Individual trace-element concentrations are affected by a number of factors, including water/ mineral equilibria controls, trace-element availability, and well-construction/drilling and sampling method effects. The effect of these identified factors is variable for individual trace-element constituents. As noted in Whiteman et al. (1994), concentrations of some trace elements are controlled by the chemical characteristics of the groundwater, while concentrations of other trace elements are a function of their availability in the existing rock units. Trace elements, such as $\mathrm{Ba}$ and $\mathrm{Fe}$, are likely controlled by the chemical characteristics of the water and solubilities of associated secondary minerals (e.g., barite and iron oxyhydroxides). In contrast, elements, such as $\mathrm{B}$ and $\mathrm{Sr}$, are usually controlled 
by the availability of the element in the aquifer rock framework. Gephart et al. (1979) reported that the sampling method (i.e., samples obtained using swab/bailing methods versus submersible pump) can also impart a discernible influence on selected trace-element constituents; specifically $\mathrm{Fe}, \mathrm{Mn}$, and $\mathrm{Zn}$. In addition, drilling fluid additives and lubricants have been identified as possible sources of elevated trace-element concentrations in some water analyses (Early et al. 1986).

The cited variable effects on trace-element concentrations and commonly reported below-detectionlevel values for trace elements limit their use for discerning hydrogeologic conditions within the upper basalt aquifer system. Selected trace elements associated with contaminants (e.g., chromium [Cr]) in past onsite wastewater-disposal sites have been used and routinely monitored for within the unconfined aquifer. The $\mathrm{Cr}$ contaminant plume areas presented in Dresel et al. (1994) tend to be of limited areal extent and are closely associated with known disposal sites in the 100 and 200 Areas on the Hanford Site. Only $22 \%$ of the upper basalt groundwater samples have values greater than the $\mathrm{Cr}$-detection limit; only one well-site location (699-50-45; $\mathrm{Cr}=170 \mu \mathrm{g} / \mathrm{L})$ exceeds federal drinking water standards $(100 \mu \mathrm{g} / \mathrm{L})$ or the Washington State maximum contaminant level $(50 \mu \mathrm{g} / \mathrm{L})$. It is not apparent whether the one elevated $\mathrm{Cr}$ value is significant as an indicator of local contamination within the upper basalt aquifer. Dresel (1994) reported that elevated levels of $\mathrm{Cr}$ within the overlying unconfined aquifer in the 200 East Area are associated with particulate matter of ultrafine or colloidal size that may pass through the $0.45-\mu \mathrm{m}$-size filter used for trace-element sample collection. Alternatively, $\mathrm{Cr}$ is also a component of the stainless steel well casing used in the area and, therefore, elevated $\mathrm{Cr}$ concentrations in samples collected from stainless steel-lined wells may not be representative of actual groundwater conditions.

\subsection{Stable Isotopes}

The analysis of groundwater for the stable isotopes of hydrogen, oxygen, sulfur, and carbon is commonly used in hydrologic investigations to establish the origin and source of groundwater within aquifer systems. As noted by Fontes (1980), if a stable isotope does not change (e.g., through isotopic-exchange processes) within an aquifer system, it can be used to assess the origin of the groundwater. If the content of a stable isotope changes along the groundwater-flow path, it may be useful in evaluating the history of the groundwater.

Stable isotopic analyses are reported as delta values $(\delta)$, using the following general equation (DOE 1988):

$$
\delta \mathrm{x}=\left(\mathrm{R}_{\text {sample }} / \mathrm{R}_{\text {standard }}\right) \times 1000 \% \text { (per mill) }
$$


where $R_{\text {sample }}=$ ratio of ${ }^{2} \mathrm{H} /{ }^{1} \mathrm{H}$ isotopes for hydrogen, ${ }^{18} \mathrm{O} /{ }^{15} \mathrm{O}$ isotopes for oxygen, ${ }^{34} \mathrm{~S} /{ }^{32} \mathrm{~S}$ isotopes for sulfur, and ${ }^{13} \mathrm{C} /{ }^{12} \mathrm{C}$ isotopes for carbon

$\mathrm{R}_{\text {standard }}=$ for hydrogen and oxygen; standard mean ocean water (Craig 1961)

$=$ for sulfur; troilite (FeS) from the Canon Diablo meteorite (Pearson and Rightmire 1980)

= for carbon; Pee Dee belemnite (Fritz and Fontes 1980).

Table 3.3 presents the range, median, and mean values for stable isotope analysis results for the upper basalt aquifer listed in the Appendix. Interpretation and discussion of the analytical results are provided below for each of the identified stable isotopes.

\subsubsection{Deuterium and Oxygen-18}

Based on meteoric water samples collected from worldwide climatological stations, Craig (1961) demonstrated that a linear relationship existed between deuterium $\left({ }^{2} \mathrm{H}\right)$ and oxygen-18 $\left({ }^{18} \mathrm{O}\right)$. The global meteoric water line defined by Craig (1961) for this stable isotopic relationship is described by the following equation:

$$
\delta^{2} \mathrm{H}=8 \delta^{18} \mathrm{O}+10
$$

Local conditions may cause shifts in the $y$-intercept and slope values for the stated global meteoric water line equation; however, the slope value is commonly close to 8 .

Table 3.3. Summary of Stable Isotope Contents Within the Upper Basalt Confined Aquifer System

\begin{tabular}{||l|c|c|c||}
\hline Constituent & $\begin{array}{c}\text { Range, } \delta \% \\
\text { (Number of Samples) }\end{array}$ & Median, $\delta \%$ & $\begin{array}{c}\text { Mean, } \delta \% \\
\pm \text { Standard Deviation }\end{array}$ \\
\hline \hline${ }^{2} \mathrm{H}$ & $\begin{array}{c}-98.0 \text { to }-157.0 \\
(\mathrm{n}=33)\end{array}$ & -140.0 & $-137.8 \pm 12.4$ \\
\hline${ }^{18} \mathrm{O}$ & $\begin{array}{c}-12.6 \text { to }-20.1 \\
(\mathrm{n}=36)\end{array}$ & -17.6 & $-17.4 \pm 1.6$ \\
\hline${ }^{34} \mathrm{~S}$ & $\begin{array}{c}+29.2 \text { to }-10.3 \\
(\mathrm{n}=28)\end{array}$ & +3.7 & $+4.4 \pm 7.3$ \\
\hline${ }^{13} \mathrm{C}$ & $\begin{array}{c}-9.3 \text { to }-16.2 \\
(\mathrm{n}=31)\end{array}$ & -12.4 & $-12.5 \pm 1.7$ \\
\hline
\end{tabular}


A number of processes cause a depletion of the heavy isotope species of oxygen and hydrogen within atmospheric moisture. Because these processes are strongly influenced by altitude and temperature effects, oxygen and hydrogen stable isotopic studies are particularly useful in hydrologic investigations for identifying particular natural recharge source areas for aquifers. The identification of recharge source areas assumes, however, that no significant modification of the isotopic composition occurs to the precipitation prior to entering the aquifer or through groundwater/rock interactions after entering the aquifer. A number of studies (e.g., Gat and Tzur 1967) have examined the effect of surficial processes on the isotopic composition of precipitation-derived recharge waters. These studies indicate that surficial evapotranspiration effects cause an enrichment of ${ }^{18} \mathrm{O}$, causing groundwater samples affected by this process to have $\delta^{2} \mathrm{H}$ versus $\delta^{18} \mathrm{O}$ plot locations displaced to the right of the established linear meteoric line relationship.

Graham (1983) established a local meteoric water line for rain and snow precipitation occurring in the Rattlesnake Hills region of the Hanford Site. The equation expressing the local stable isotopic relationship between $\delta^{2} \mathrm{H}$ and $\delta^{18} \mathrm{O}$ is shown in Figure 3.4 and is reported by Graham (1983) as:

$$
\delta^{2} \mathrm{H}=5.8 \delta^{18} \mathrm{O}-33
$$

The deviation of the local meteoric water line from the global meteoric water line is reported by Graham (1983) to be associated with nonequilibrium evaporation processes and the relatively short storm-event durations that are characteristic of the region.

Comparison of the stable isotopic plotting positions of upper basalt groundwaters with river and spring waters in Figure 3.4 indicates a number of distinct grouping differences and associations, including:

- generally lighter stable isotopic content for the upper basalt confined aquifer system

- distinct plot groupings for Columbia River and Yakima River waters

- association between southern offsite wells and Yakima River water.

Examination of Figure 3.4 indicates that Yakima River waters exhibit stable isotopic contents that are heavier isotopically than waters from the Columbia River. This isotopic difference is associated with different geographic/climatologic regions (i.e., distance from moisture source, elevation/basin area hypsometric relationships), providing stream-flow runoff for the respective river drainages. 


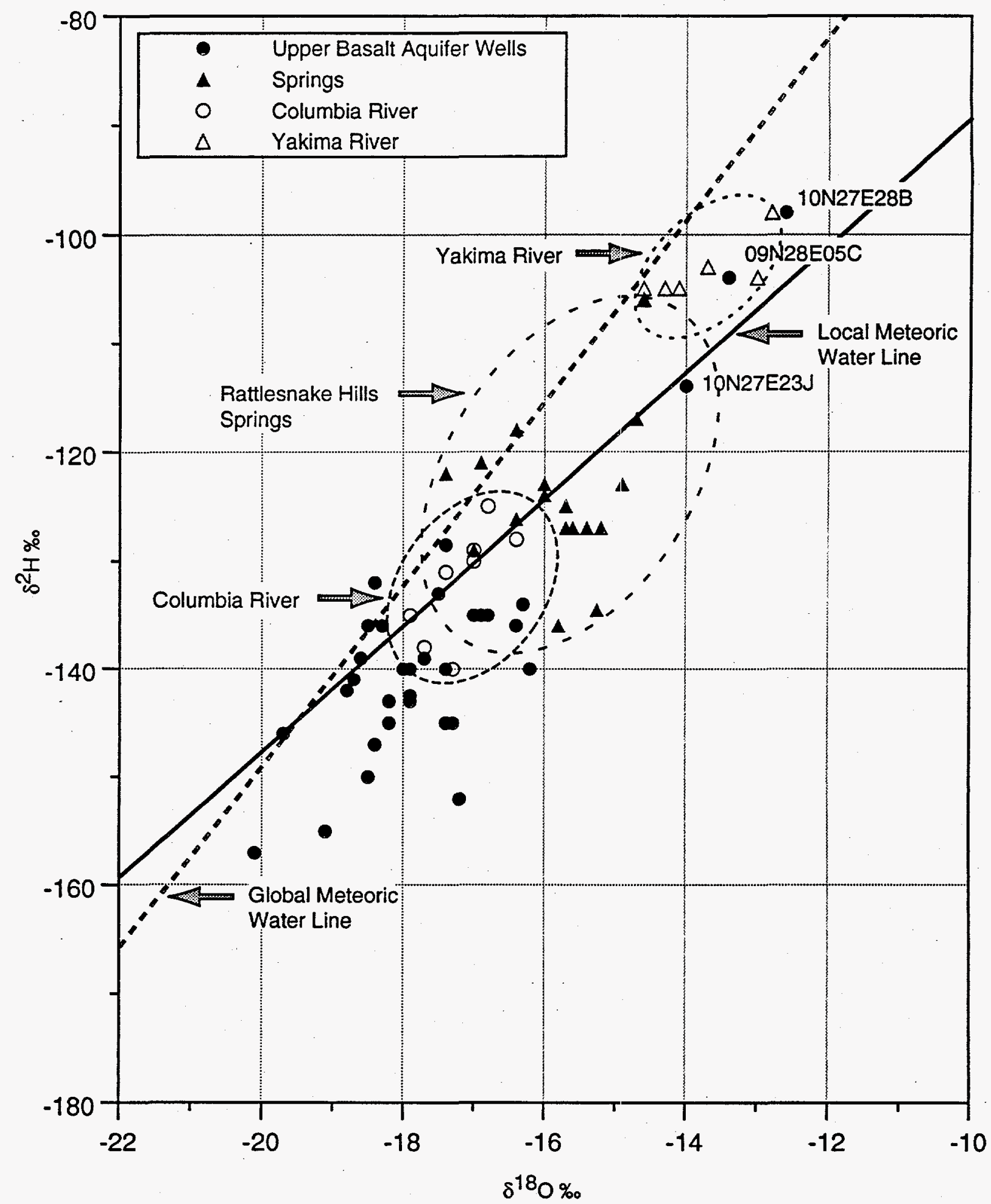

Figure 3.4. Relationship of $\delta^{2} \mathrm{H}$ and $\delta^{18} \mathrm{O}$ for the Upper Basalt Confined Aquifer System and Selected Spring and River Waters 
This is similar to regional findings reported in DOE (1988) for waters of the Columbia and Yakima rivers. Springs issuing from basalt formations in the Rattlesnake Hills region of the Hanford Site plot transitionally between waters of the Columbia and Yakima rivers as shown in Figure 3.4.

The use of stable isotopic information to identify the recharge source of groundwater is specifically shown in Figure 3.4 for offsite upper basalt wells (wells 09N28E05C, 10N27E23J, 10N27E28B) located immediately south of the Yakima River. The close plotting position of Yakima River waters to these wells strongly suggests a significant recharge component of Yakima River water to the upper basalt aquifer in this area. This association is also supported by known intensive application of Yakima River water for irrigation in this region and other hydrochemical parameter associations (see Sections 3.1, 3.5.1, and 3.5.2), suggesting recent surfacewater-recharge input to the upper basalt confined aquifer system in this area.

In contrast to these groundwaters, Hanford Site upper basalt aquifer samples exhibit a significantly different stable isotopic grouping. Although some overlap in the $\delta^{2} \mathrm{H}$ ranges is evident in examining Figure 3.4, generally upper basalt aquifer waters are isotopically lighter (i.e., more negative) than river- or spring-water samples. The enrichment of $\delta^{2} \mathrm{H}$ (i.e., more positive value) is expected for surfacewater samples experiencing equilibrium evaporative processes with the atmosphere. The $\delta^{2} \mathrm{H}$ and $\delta^{18} \mathrm{O}$ content of shallow basalt groundwaters is also reported by Graham (1983) to be similar isotopically to local precipitation that occurs during the winter months in the Rattlesnake Hills area. This suggests that precipitation that recharged the upper basalt aquifer in the past was consistent with current climatic conditions occurring in this known natural recharge area for the upper basalt confined aquifer system.

Figures 3.5 and 3.6 show the frequency distribution of $\delta^{2} \mathrm{H}$ and $\delta^{18} \mathrm{O}$, respectively, within (a) the upper basalt aquifer system and (b) the major rivers (i.e., Columbia and Yakima rivers) and springs issuing from basalt formations in the Rattlesnake Hills region of the Hanford Site, respectively. Statistical analysis of $\delta^{2} \mathrm{H}$ values listed in the Appendix for the upper basalt aquifer indicates a mean value of $-137.8 \pm 12.4 \%$ and a median value of $-140.0 \%$, with approximately $80 \%$ of the upper basalt aquifer groundwaters having $\delta^{2} \mathrm{H}$ values between -150 and $-130 \%$. Analysis of $\delta^{18} \mathrm{O}$ values indicates a mean value of $-17.4 \pm 1.6 \%$ and a median value of $-17.6 \%$, with approximately $85 \%$ of the groundwaters having $\delta^{18} \mathrm{O}$ values between -19.0 and $-16.0 \%$. The previously discussed association of Yakima River water and offsite wells located immediately south of the Yakima River is also evident in comparing the histogram plots presented in Figures 3.5 and 3.6. 
(a)

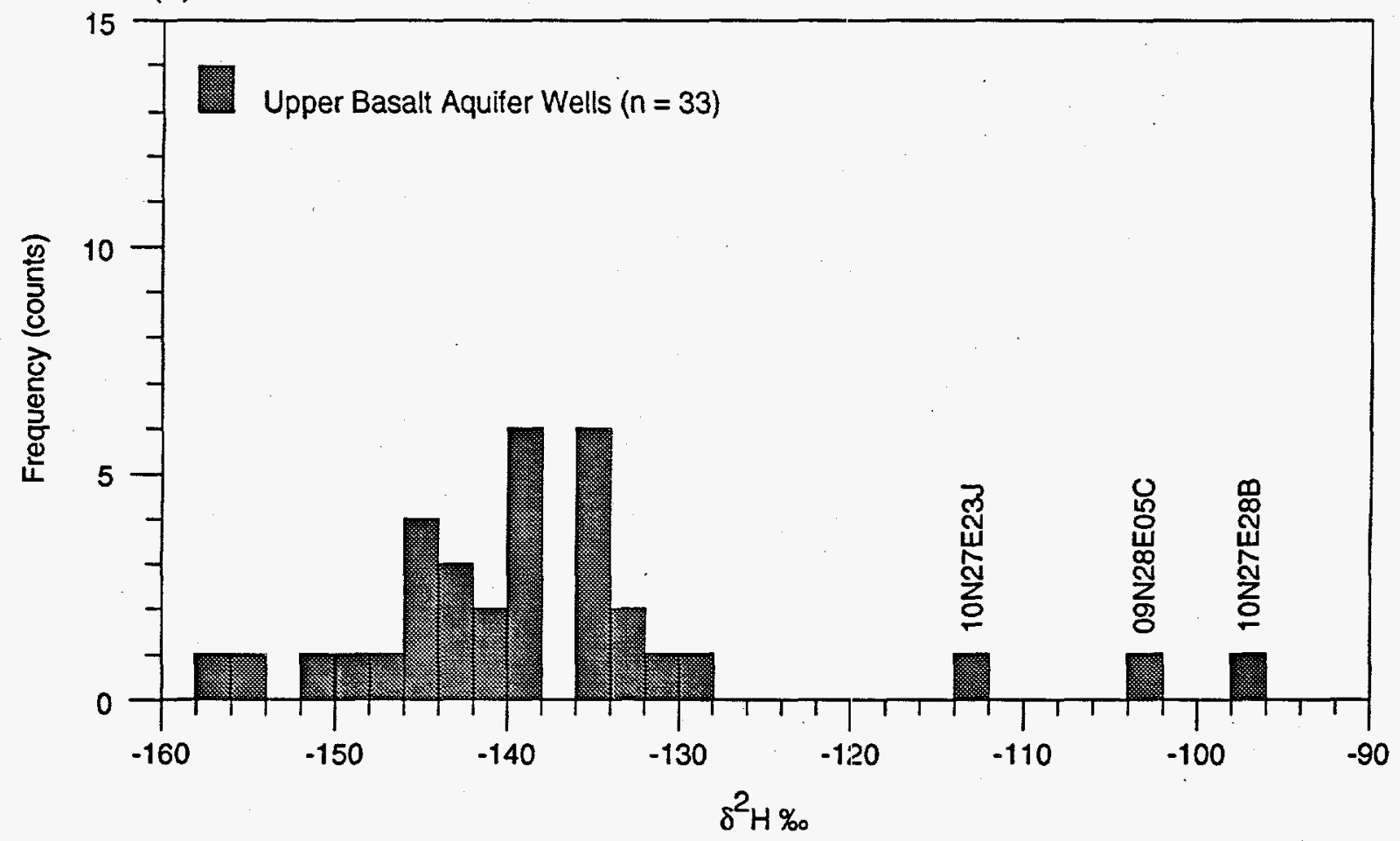

(b)

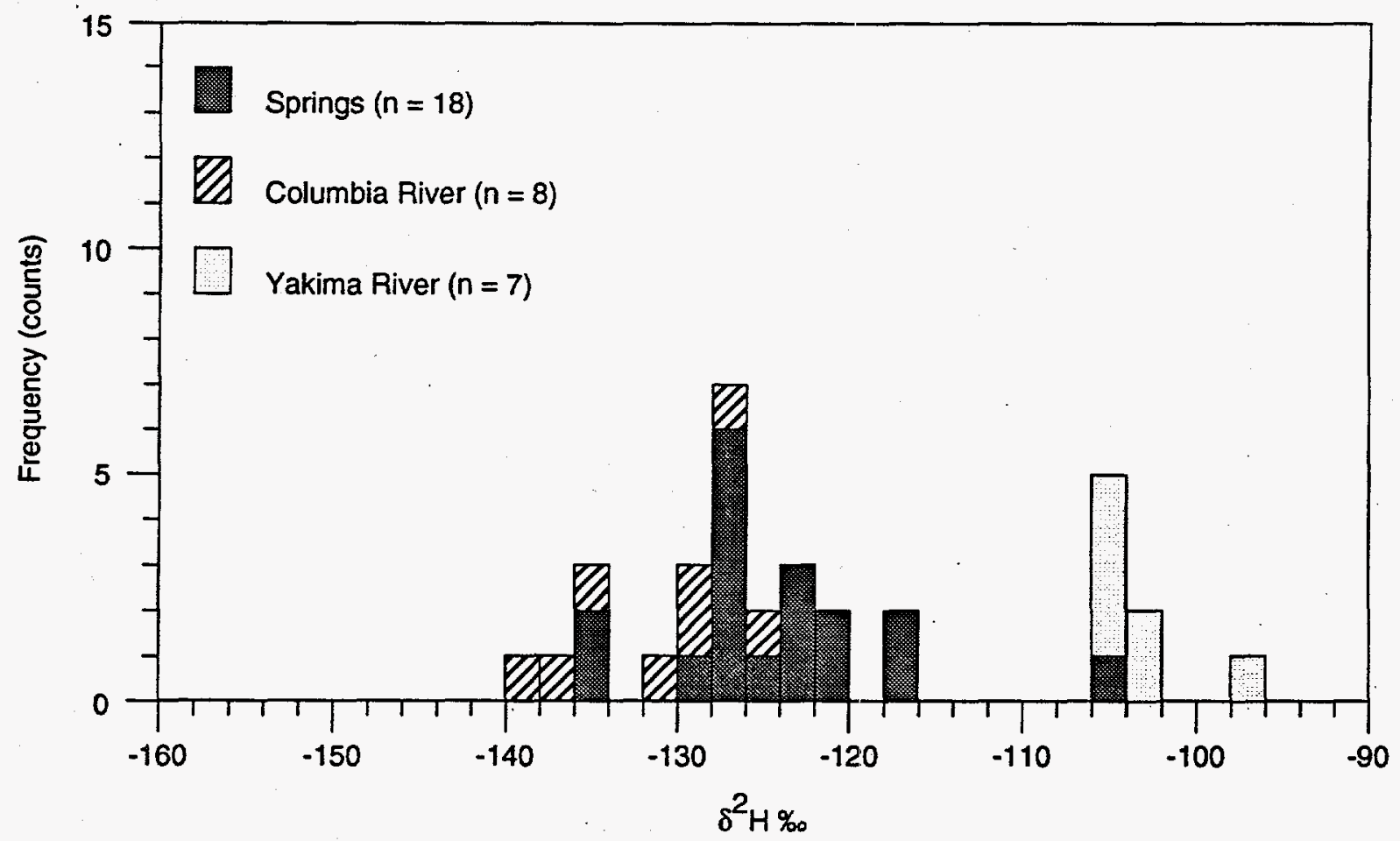

Figure 3.5. Histograms Showing the Frequency Distribution of $\delta^{2} \mathrm{H}$ Within the (a) Upper Basalt Confined Aquifer System and (b) Rivers and Springs on the Hanford Site 


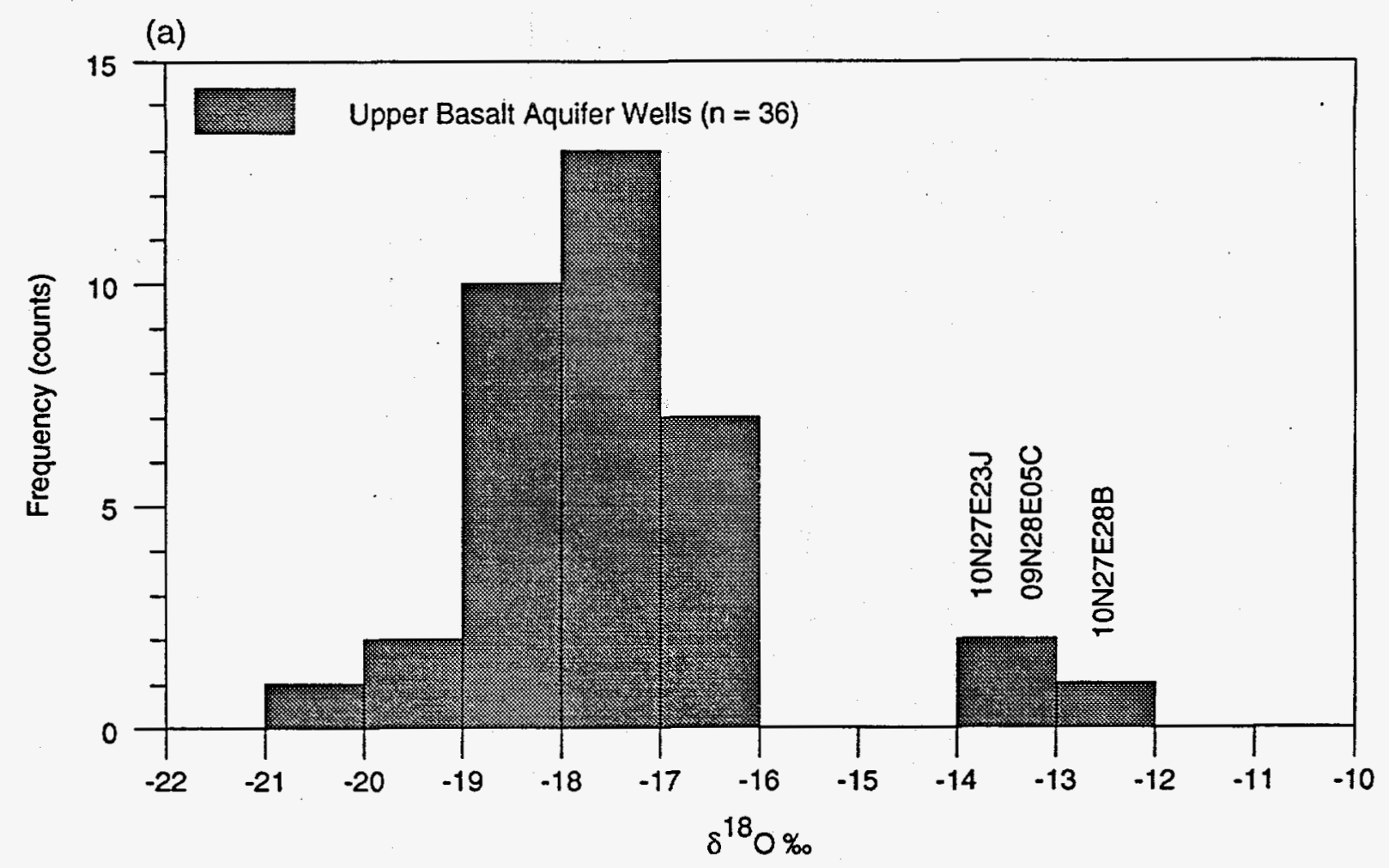

(b)

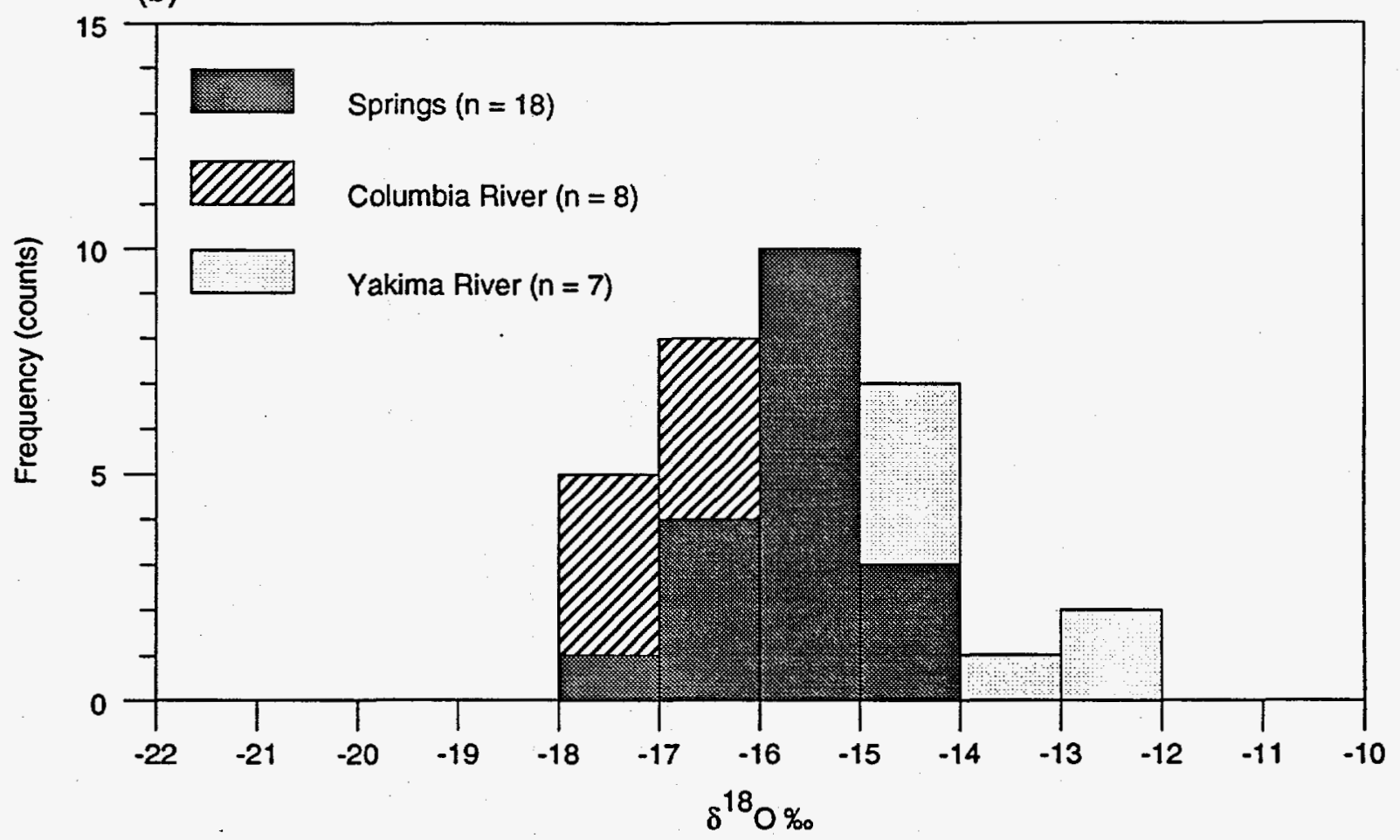

Figure 3.6. Histograms Showing the Frequency Distribution of $\delta^{18} \mathrm{O}$ Within the (a) Upper Basalt Confined Aquifer System and (b) Rivers and Springs on the Hanford Site 


\subsubsection{Sulfur-34}

Sulfur isotopes can be used to determine the mineralogic origin of sulfur species and identify the processes controlling the concentrations of sulfur in the groundwater system. Sulfate, bisulfate, and hydrogen sulfide are the common sulfur-bearing species commonly found in low-temperature groundwater systems. The sulfur species prevalent in groundwater are dependent on the $\mathrm{pH}$ and $\mathrm{Eh}$ conditions of the system. Sulfur has four stable isotopes: ${ }^{32} \mathrm{~S},{ }^{33} \mathrm{~S},{ }^{34} \mathrm{~S}$, and ${ }^{35} \mathrm{~S}$, the most common being ${ }^{32} \mathrm{~S}$ and ${ }^{34} \mathrm{~S}$, which have relative abundances of $94.9 \%$ and $4.3 \%$, respectively (Rightmire et al. 1974). The remaining sulfur isotopes make up the remaining $0.8 \%$.

The isotopic composition of sulfur is commonly expressed using the ratio of ${ }^{34} \mathrm{~S} /{ }^{32} \mathrm{~S}$ in standard $\delta$ units, with the standard reference for the sulfur isotope analyses being for troilite in the Canon Diablo meteorite standard (Pearson and Rightmire 1980). The mean sulfur isotopic values $\left(\delta^{34} \mathrm{~S} \%\right.$ ) for various common sources of sulfate in groundwater are listed by Rightmire et al. (1974) as: seawater mean $=+20.3 \%$, range $=+18.9$ to $+20.7 \%$; atmospheric precipitation mean $=+8.1 \%$, range $=-1.5$ to $+19.4 \%$; ; biogenic hydrogen sulfide mean $=-15 \%$, range $=-35$ to $+4 \%$; and sedimentary rocks/sulfide minerals mean $=-15 \%$, range $=-35$ to $+42 \%$. Sources of sulfur contributing to sulfate in the upper basalt aquifer groundwater likely include atmospheric precipitation and sulfide minerals. As noted in Spane et al. (1982), the presence of common secondary sulfide minerals within basalt flows suggests that oxidation of pyrite is the primary source of dissolved sulfate for upper basalt groundwaters on the Hanford Site. Agricultural practices (fertilizer application and leaching by applied irrigation waters) are also potential sources of sulfate for offsite groundwaters (e.g., east of the Columbia River, south of the Yakima River).

Figure 3.7 shows the frequency distribution of $\delta^{34} \mathrm{~S}$ for dissolved sulfate within (a) the upper basalt aquifer system and (b) the major rivers (i.e., Columbia and Yakima rivers) and springs issuing from basalt formations in the Rattlesnake Hills region of the Hanford Site, respectively. Although a widerange of $\delta^{34} \mathrm{~S}$ values is indicated, general overlap and agreement between most $\delta^{34} S$ values for upper basalt aquifer groundwaters and river and spring waters are indicated. Statistical analysis of $\delta^{34} \mathrm{~S}$ values listed in the Appendix for the upper basalt aquifer indicates a mean value of $+4.4 \pm 7.3 \%$ and a median value of $+3.7 \%$, with approximately $85 \%$ of the upper basalt aquifer groundwaters having $\delta^{34} S$ values between -6 and $+8 \%$. The cited range of $\delta^{34} \mathrm{~S}$ values for the upper basalt aquifer system is consistent with values reported in Spane et al. (1982) and DOE (1988) for Saddle Mountains Basalt groundwaters.

The four wells that have $\delta^{34} \mathrm{~S}$ values outside the -6 to $+8 \%$ range are identified in Figure 3.7 (a). Wells $699-42-\mathrm{E} 9 \mathrm{~B}$ and $12 \mathrm{~N} 28 \mathrm{E} 23 \mathrm{H}$ are located immediately outside the Hanford Site to the east of the Columbia River. Their isotopic contents, therefore, may reflect possible differences in groundwater recharge sources and flow-pattern characteristics. The cause for the $\delta^{34} S$ divergence observed at wells 
(a)

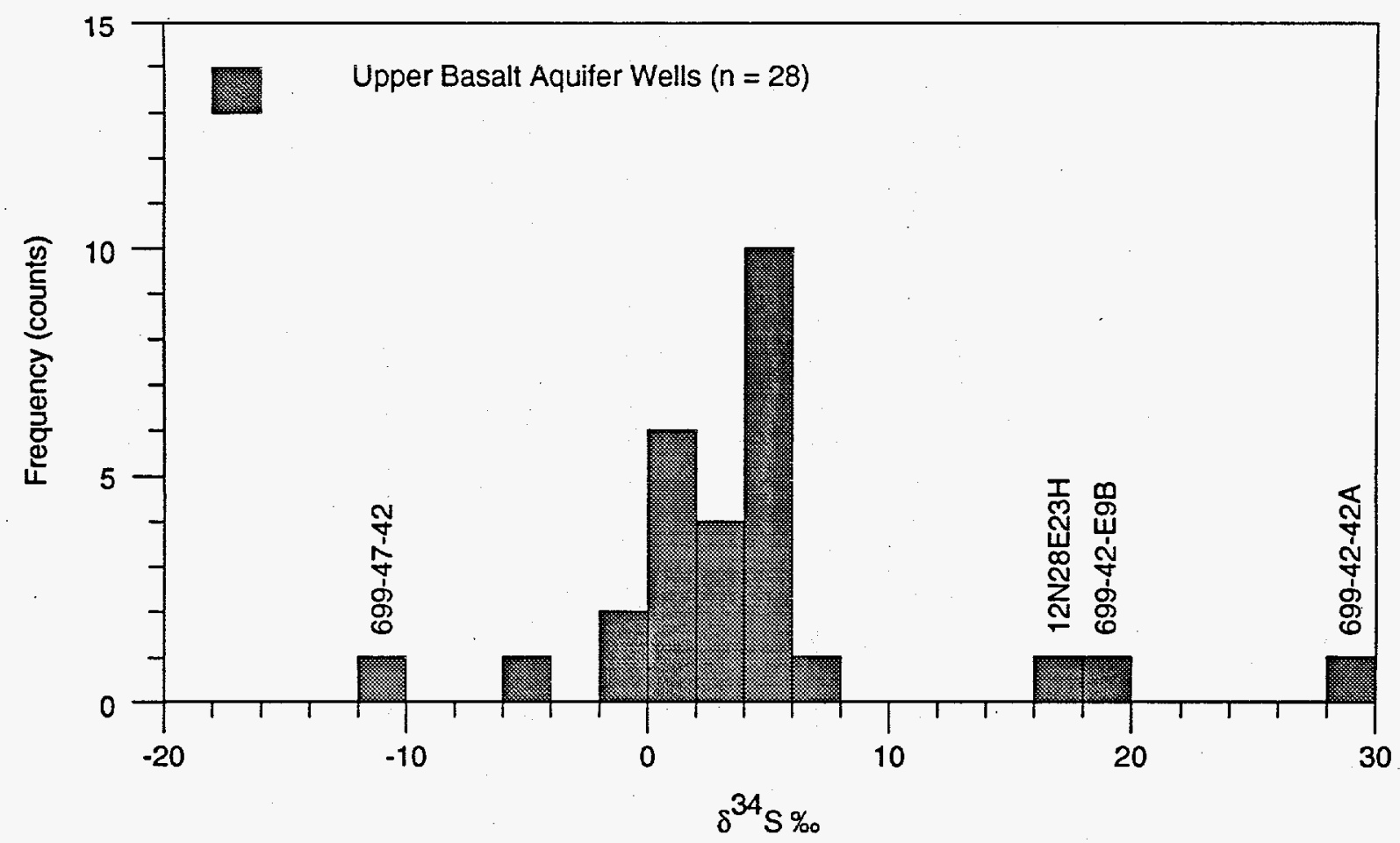

(b)

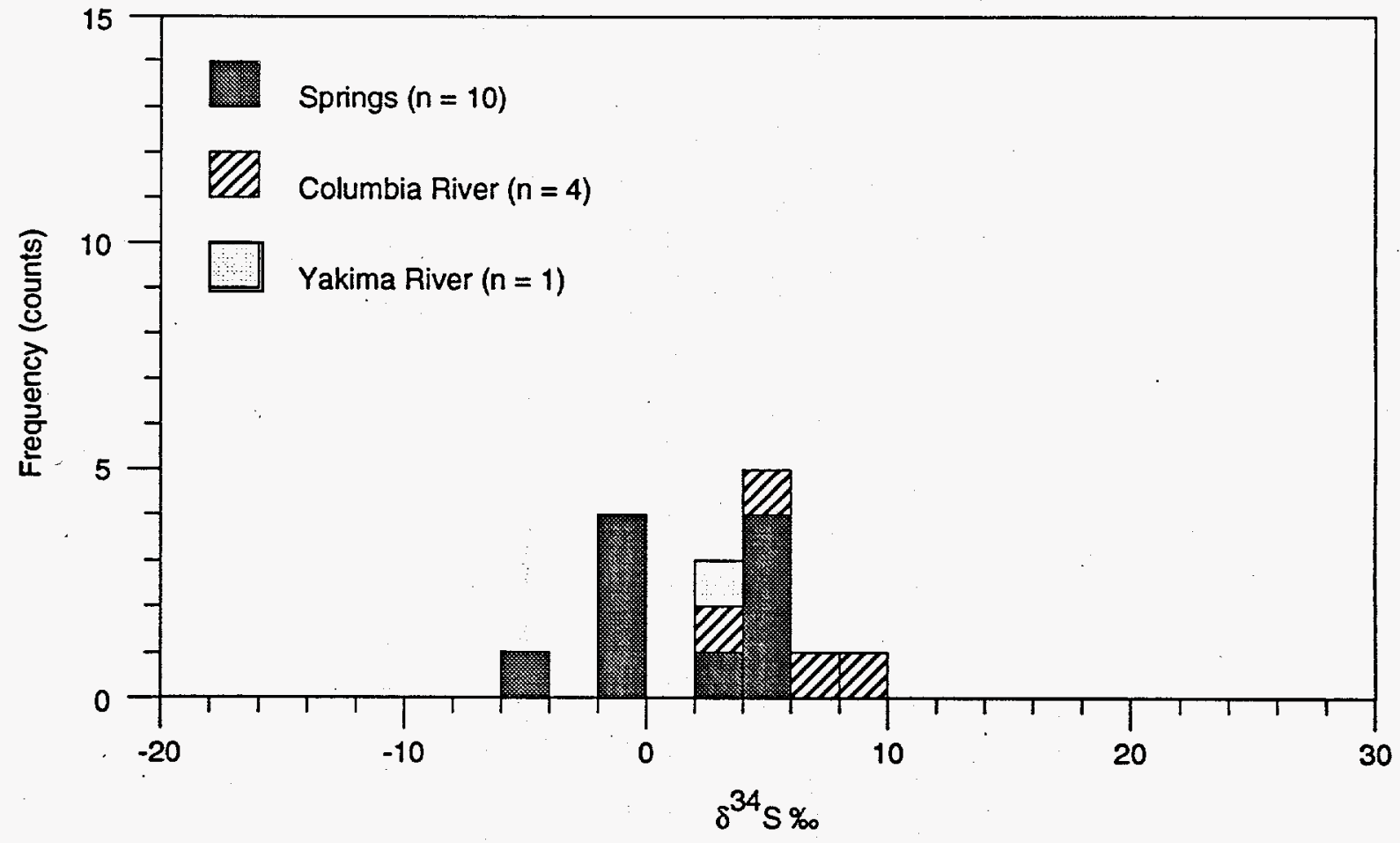

Figure 3.7. Histograms Showing the Frequency Distribution of $\delta^{34} S$ Within the (a) Upper Basalt Confined Aquifer System and (b) Rivers and Springs on the Hanford Site 
699-42-42A and 699-47-42 is unknown. However; their proximity to known wastewater-discharge facilities (i.e., cribs, trenches, ponds) in the 200 East Area and vicinity suggests that sources associated with these activities may be responsible.

\subsubsection{Carbon-13}

Determining the $\delta^{13} \mathrm{C}$ content of $\mathrm{HCO}_{3}$ within groundwater is commonly used in hydrologic studies for determining the source of the dissolved carbonate $\left(\mathrm{CO}_{3}^{-2}\right)$ species within an aquifer system. This is of particular importance for providing corrections to ${ }^{14} \mathrm{C}$ measurements used for determining groundwater-residence time or flow velocities within aquifer systems (Section 3.5.2). Figure 3.8 shows the frequency distribution of $\delta^{13} \mathrm{C}$ within (a) the upper basalt aquifer system and (b) the major rivers (i.e., Columbia and Yakima rivers) and springs issuing from basalt formations in the Rattlesnake Hills region of the Hanford Site, respectively. As shown, close agreement between the predominant range of $\delta^{13} \mathrm{C}$ for upper basalt aquifer groundwaters and river and spring waters is indicated.

Statistical analysis of $\delta^{13} \mathrm{C}$ values listed in the Appendix for the upper basalt aquifer indicates a mean value of $-12.5 \pm 1.7 \%$ and a median value of $-12.4 \%$, with approximately $85 \%$ of the upper basalt aquifer groundwaters having $\delta^{13} \mathrm{C}$ values between -10 and $-15 \%$. This range is consistent with the values reported by Wallick (1976) and Mook (1980) for semiarid, high-evapotranspiration climate regions, where the primary $\mathrm{CO}_{3}^{-2}$ sources are vegetation, soil gas, and dissolution of calcareous soil precipitates. The lack of an associated correlation between $\mathrm{HCO}_{3}$ concentration and $\delta^{13} \mathrm{C}$ (Figure 3.9 [a]) and ${ }^{14} \mathrm{C}$ content (Figure $3.9[\mathrm{~b}]$ ) and similar $\delta^{13} \mathrm{C}$ range for springs issuing from basalt formations (see Figure 3.8) suggest that dilution of the ${ }^{14} \mathrm{C}$ content through additions of "dead carbon" (i.e., ${ }^{14} \mathrm{C}=0.0$ percent modern carbon $[\mathrm{PMC}]$ ) may be minimal for groundwater within the upper basalt confined aquifer system. This indicates that corrections for ${ }^{14} \mathrm{C}$ groundwater age-dating or flowvelocity calculations may not be required. A similar finding concerning carbon source corrections for ${ }^{14} \mathrm{C}$ applications was reported earlier by DOE (1988) for basalt groundwater within the region.

\subsection{Unstable Isotopes}

Unstable (i.e., radioactive) isotopes have been used in a fashion similar to stable isotopes for characterizing groundwater in hydrologic investigations. Studies using unstable isotopes have also been successfully applied for direct indications of radionuclide contanination within aquifers and for determining groundwater age, residence time, and flow velocity within aquifer systems. Table 3.4 presents the range, median, and mean values for unstable isotope analysis results for the upper basalt aquifer and are listed in the Appendix. Interpretation and discussion of the analytical results are provided below for each of the identified unstable isotopes. 
(a)

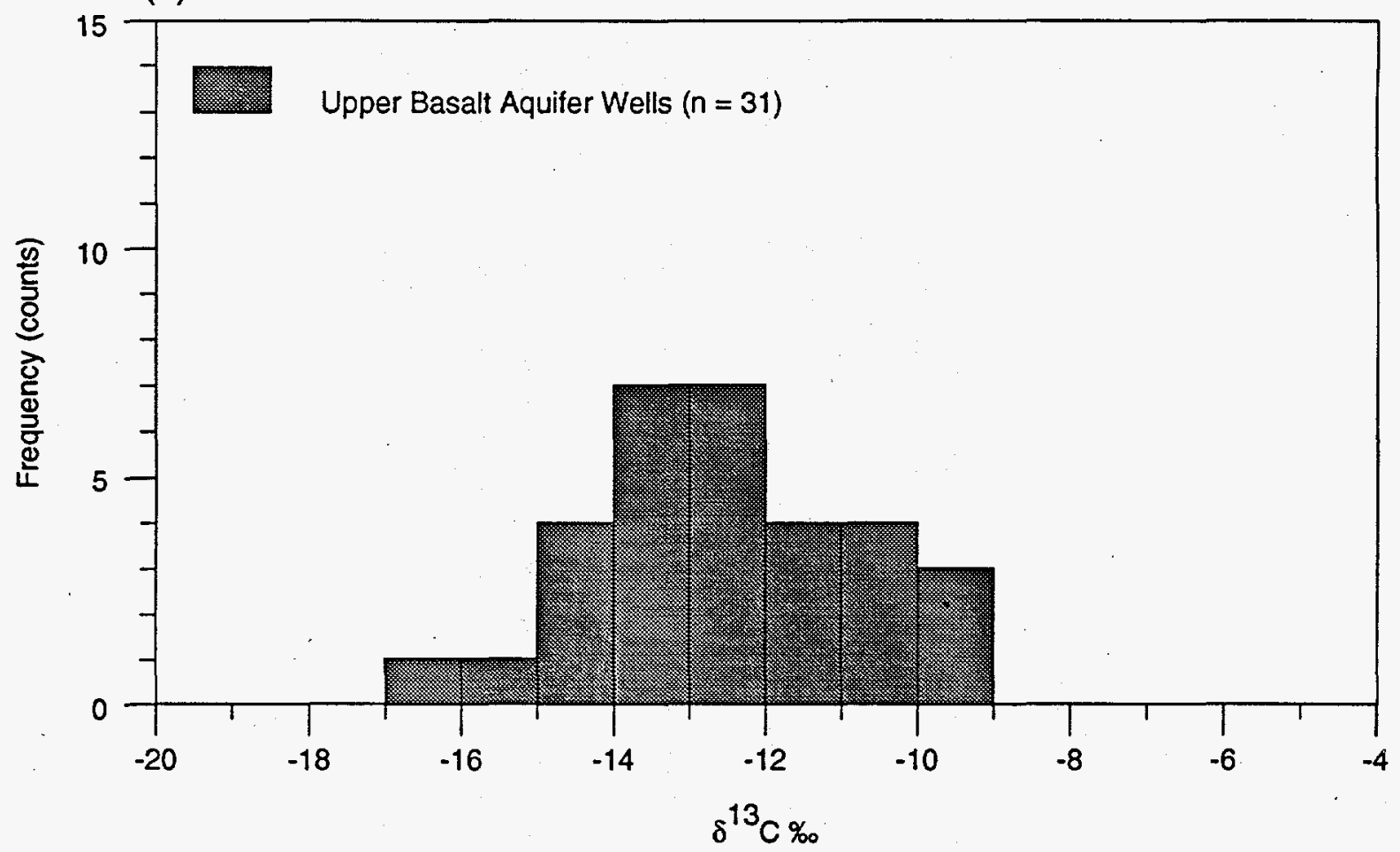

(b)

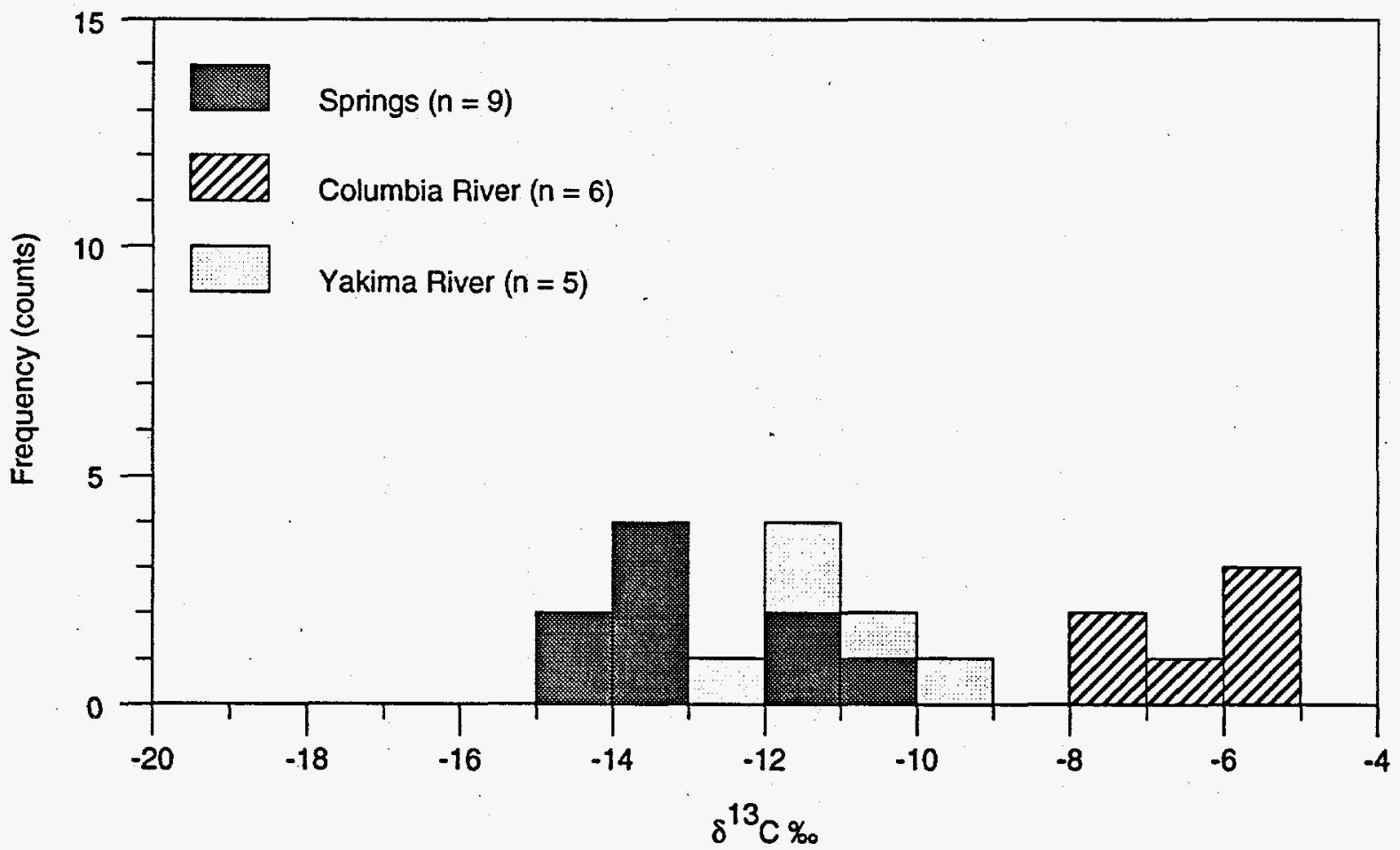

Figure 3.8. Histograms Showing the Frequency Distribution of $\delta^{13} \mathrm{C}$ Within the (a) Upper Basalt Confined Aquifer System and (b) Rivers and Springs on the Hanford Site 
(a)

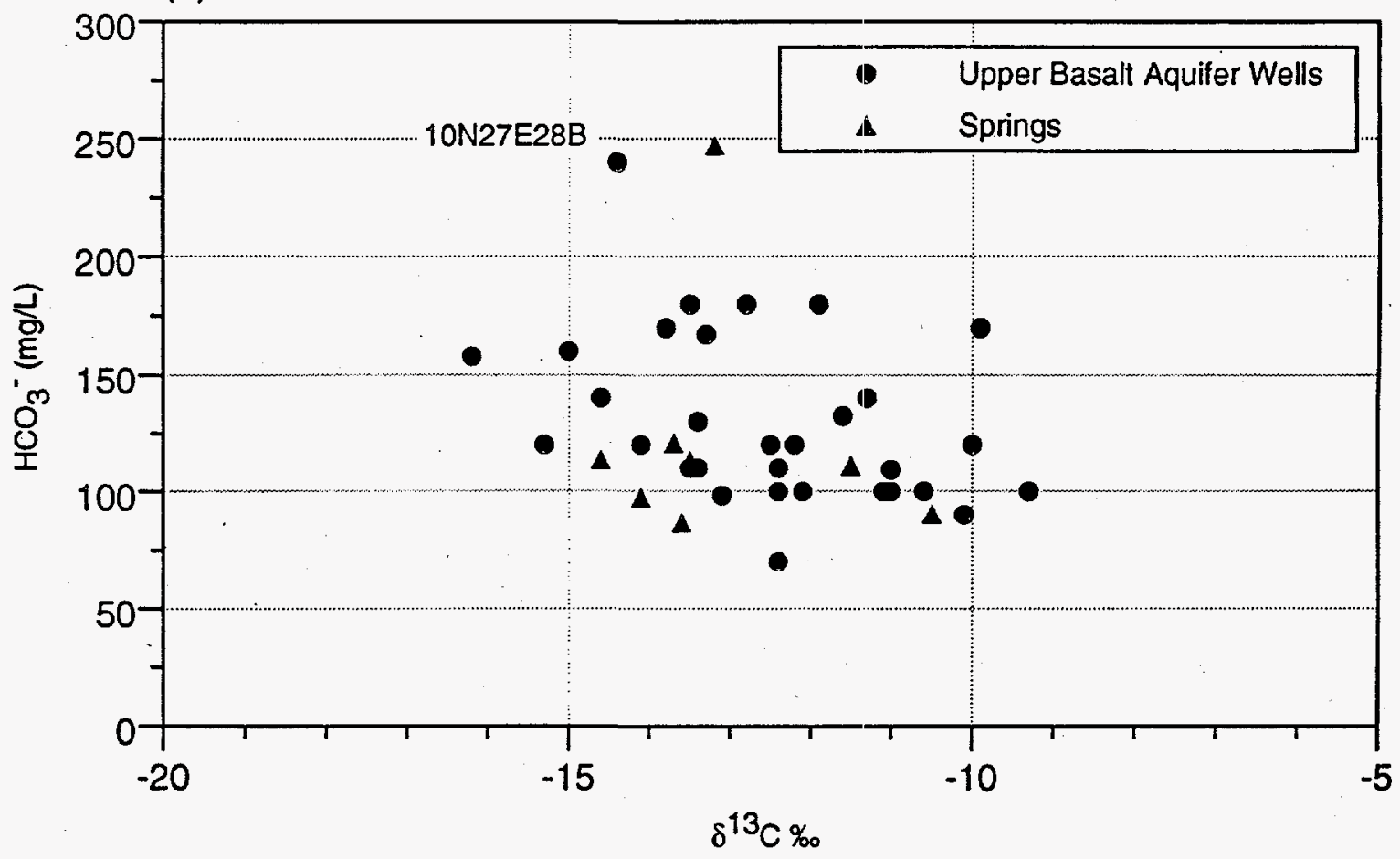

(b)

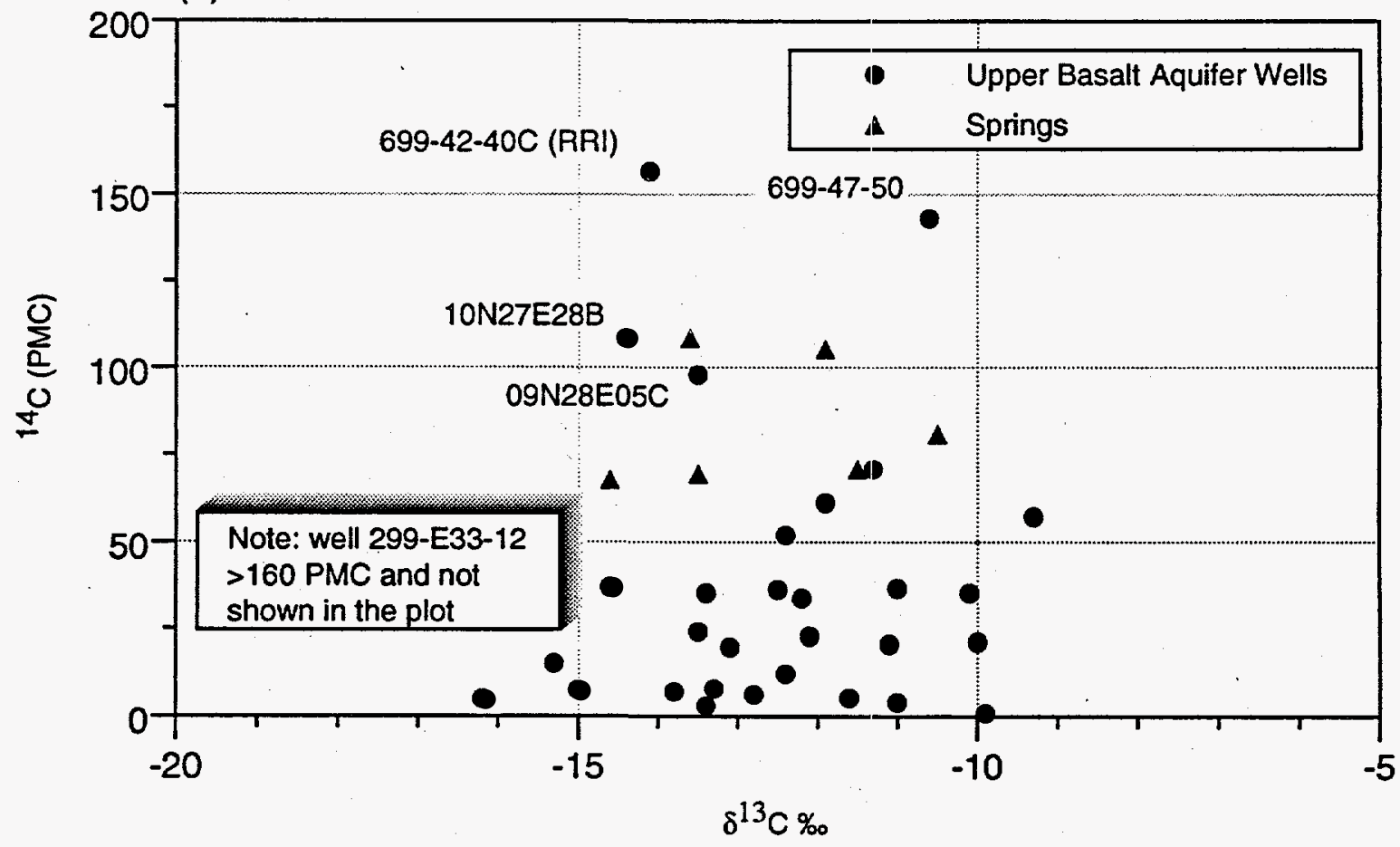

Figure 3.9. Relationship of (a) $\mathrm{HCO}_{3}^{-}$and ${ }^{13} \mathrm{C}$ and (b) ${ }^{14} \mathrm{C}$ and ${ }^{13} \mathrm{C}$ Within the Upper Basalt Confined Aquifer System and Rattlesnake Hills Springs Issuing from Basalt 
Table 3.4. Summary of Unstable Isotope Contents Within the Upper Basalt Confined Aquifer System

\begin{tabular}{||l|c|c|c||}
\hline $\begin{array}{c}\text { Constituent (Unit } \\
\text { of Measurement) }\end{array}$ & $\begin{array}{c}\text { Range } \\
\text { (Number of Samples) }\end{array}$ & Median & $\begin{array}{c}\text { Mean } \\
\text { Standard Deviation }\end{array}$ \\
\hline \hline $\begin{array}{l}{ }^{3} \mathrm{H} \\
(\mathrm{TU})\end{array}$ & $\begin{array}{c}\text { BDL to } 2481 \\
(\mathrm{n}=36)\end{array}$ & 0.10 & NA \\
\hline $\begin{array}{l}{ }^{14} \mathrm{C} \\
(\mathrm{PMC})\end{array}$ & $\begin{array}{c}0.9 \text { to } 2234.0 \\
(\mathrm{n}=34)\end{array}$ & 27.1 & $101.7 \pm 378.7$ \\
\hline $\begin{array}{l}{ }^{129} \mathrm{I} \\
(\mathrm{pCi} / \mathrm{L})\end{array}$ & $\begin{array}{c}\mathrm{BDL} \text { to } 3.7 \mathrm{E}-2 \\
(\mathrm{n}=23)\end{array}$ & $2.1 \mathrm{E}-04$ & NA \\
\hline $\mathrm{BDL}=$ Below detection limit. & \\
$\mathrm{NA}=$ Not applicable. & & \\
$\mathrm{PMC}=$ Percent modern carbon. & \\
$\mathrm{TU}=$ Tritium units; equal to 3.193 picoCuries/liter. & \\
\hline
\end{tabular}

\subsubsection{Tritium}

Tritium $\left({ }^{3} \mathrm{H}\right)$ is produced naturally in the atmosphere by the effects of cosmic ray bombardment and by man-related activities associated with atmospheric thermonuclear weapons testing. Because of its relatively short half-life (i.e., 12.35 years), ${ }^{3} \mathrm{H}$ is limited to practical age-dating natural groundwaters with ages of approximately 40 years or less (Davis 1989). While ${ }^{3} \mathrm{H}$ is of little value for agedating groundwaters within the upper basalt aquifer system, it does provide valuable insight pertaining to the presence of tritiated drilling fluid contamination within the groundwater samples and hydrologic intercommunication with the overlying contaminated unconfined aquifer.

For most basalt boreholes/wells drilled in the 1980s as part of the Basalt Waste Isolation Project (BWIP) on the Hanford Site, ${ }^{3} \mathrm{H}$ was used as a natural tracer. Drilling fluids were mixed with Columbia River-based water, which has elevated levels of ${ }^{3} \mathrm{H}$. The level of ${ }^{3} \mathrm{H}$ within the Columbia River has decreased because of a decline in the amount of atmospheric nuclear weapons testing over the past three decades. Early et al. (1986) reported ${ }^{3} \mathrm{H}$ levels within Columbia River water at Priest Rapids Dam (located immediately upstream of the Hanford Site) that range from 300 to 600 tritium units (TU) measured in 1969 and that decline to 25 to 32 TU during the 1985-1986 time period. Recently, Dirkes (1994) reported ${ }^{3} \mathrm{H}$ levels decreasing from $\sim 20$ to $<15$ TU between 1988 and 1993. Graham (1984) suggested that BWIP basalt groundwater samples containing ${ }^{3} \mathrm{H}$ levels of $<1 \mathrm{TU}$ indicate only minor levels of drilling fluid contamination and permit use of the major inorganic and stable isotopic data for hydrochemical characterization applications. BWIP data used as part of the hydrochemical characterization of the upper basalt aquifer presented in this report are from the following wells: 699-S16-E14 
(Levey interbed), 699-S16-E14 (Rattlesnake Ridge interbed), 699-47-42, 699-84-34B (Elephant Mountain Member interflow), and 699-84-34B (Rattlesnake Ridge interbed). These wells, except for well 699-47-42, utilized Columbia River water as a component of the drilling fluid. ${ }^{3} \mathrm{H}$, therefore, could be used for assessing drilling fluid contamination within these upper basalt groundwater samples. Well $699-47-42$ is located within the vicinity of an area suspected of intercommunication between the unconfined and upper basalt confined aquifer systems. Because ${ }^{3} \mathrm{H}$ contamination of the upper basalt system is possible through aquifer intercommunication in this area, a source of nontritiated water (i.e., ${ }^{3} \mathrm{H} \leq 0.1 \mathrm{TU}$ ) was utilized by the BWIP at this well site while drilling through the entire Saddle Mountains Basalt section.

Figure 3.10 shows the frequency distribution of ${ }^{3} \mathrm{H}$ within (a) the upper basalt aquifer system and (b) the major rivers (i.e., Columbia and Yakima rivers) and springs issuing from basalt formations in the Rattlesnake Hills region of the Hanford Site, respectively. Statistical analysis of ${ }^{3} \mathrm{H}$ values listed in the Appendix for the upper basalt aquifer indicates a median value of $0.10 \mathrm{TU}$, with approximately $65 \%$ of the upper basalt aquifer groundwaters having ${ }^{3} \mathrm{H}$ values of $<1.0 \mathrm{TU}$. (Note: a calculated mean value is not applicable because many values are below the reported laboratory detection limit; i.e., $0.10 \mathrm{TU}$ ). Ten groundwater samples exhibit ${ }^{3} \mathrm{H}$ values $>5 \mathrm{TU}$, with a maximum value of 2486 TU observed for well 699-42-40C (Rattlesnake Ridge interbed). Most of the upper basalt groundwaters exhibiting elevated ${ }^{3} \mathrm{H}$ values are located in the 200 East Area-Gable Mountain region, an area of suspected intercommunication with the overlying contaminated unconfined aquifer. Four wells (not shown in Figure 3.10 [a]) with elevated ${ }^{3} \mathrm{H}$ values (i.e., >50 TU) are significantly greater than the values shown in Figure 3.10 (b) or reported in Dirkes (1994) for Columbia River water or for waters from the B Pond disposal facility (which received Columbia River process-cooling waters) for the 1988-1993 time period. This suggests that the elevated ${ }^{3} \mathrm{H}$ values for these wells are attributable, in part, to a component of radioactive waste discharged from disposal facilities in the immediate 200 East Area.

Offsite wells located south of the Yakima River exhibit ${ }^{3} \mathrm{H}$ values that are slightly elevated ( 5 to $19 \mathrm{TU}$ ), and are similar to ${ }^{3} \mathrm{H}$ levels observed for the Yakima River (i.e., 12 to 14 TU 1985-1986 time period). This is consistent with previous discussions of other hydrochemical parameters (see Sections 3.1 and 3.4.1) that indicate a recharge input component of Yakima River water to the upper basalt aquifer in this area.

\subsubsection{Carbon-14}

Carbon-14 $\left({ }^{14} \mathrm{C}\right)$ is commonly used in hydrologic investigations for the determination of groundwater-residence time, age-dating, and flow-velocity estimates. Standard laboratory analytical capabilities limit ${ }^{14} \mathrm{C}$ applications for age-dating and/or residence-time calculations in the 500- to 50,000-year range (Davis 1989). 
(a)

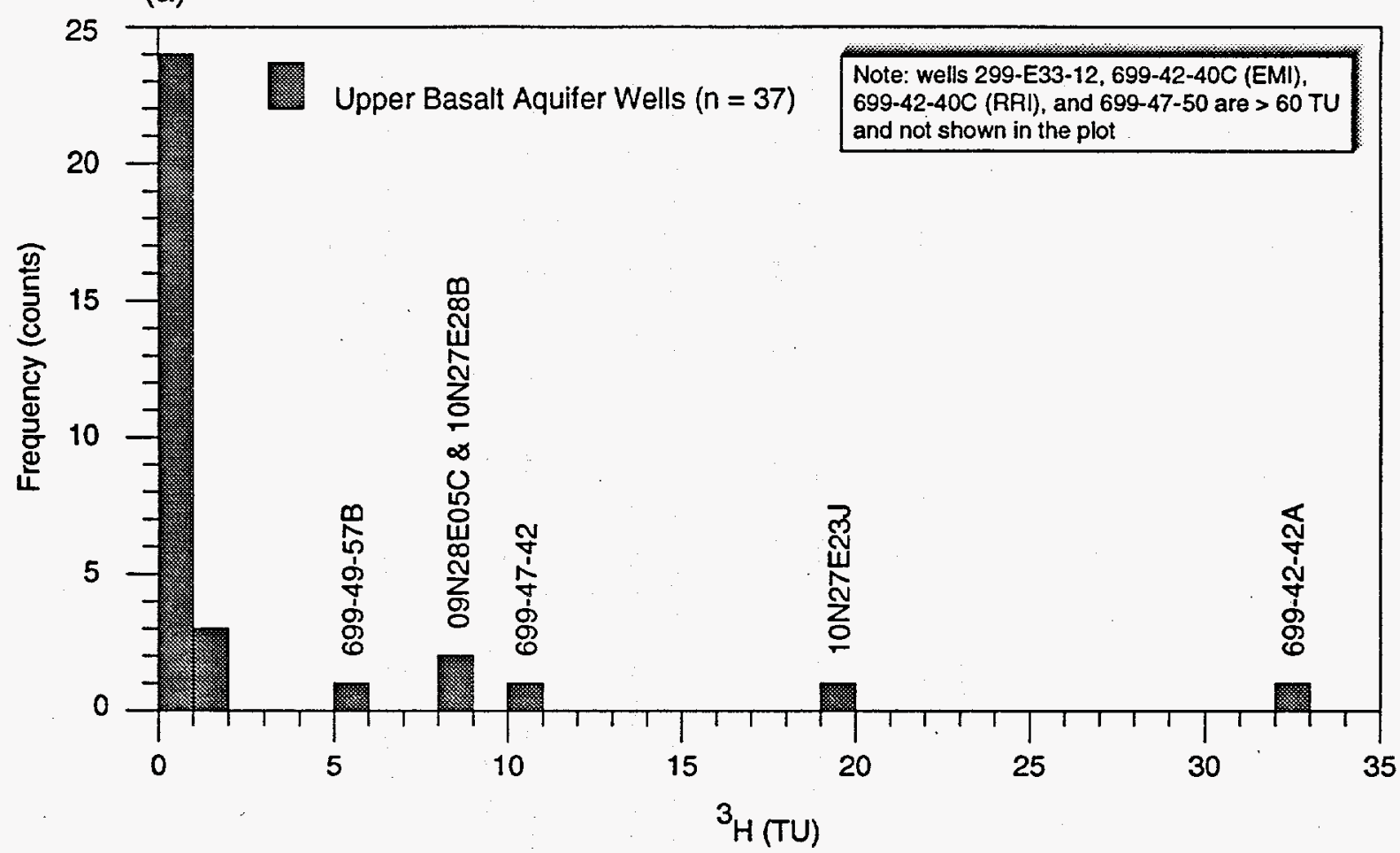

(b)

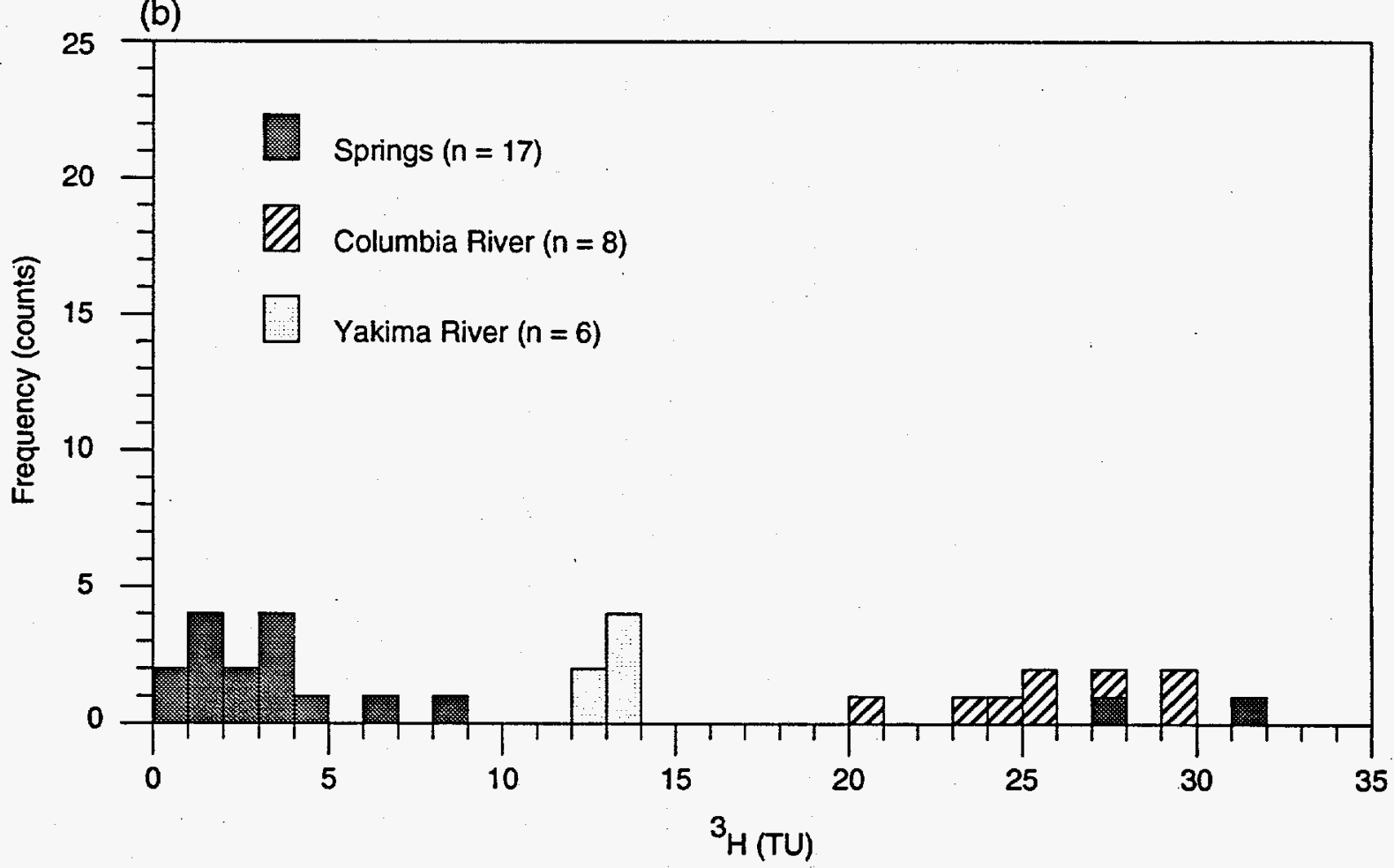

Figure 3.10. Histograms Showing the Frequency Distribution of ${ }^{3} \mathrm{H}$ Within the (a) Upper Basalt Confined Aquifer System and (b) Rivers and Springs on the Hanford Site 
${ }^{14} \mathrm{C}$ is produced continuously in the atmosphere by the action of cosmic ray bombardment of nitrogen-14 atoms. The radiogenic ${ }^{14} \mathrm{C}$ produced by this process is oxidized to carbon dioxide and is readily mixed and dispersed within the atmospheric reservoir. Recharge water entering an aquifer absorbs carbon dioxide from the aerated soil zone, which forms $\mathrm{CO}_{3}^{-2}$ and $\mathrm{HCO}_{3}^{-}$ions in solution. The carbon dioxide absorbed in the soil zone is derived from soil gas produced through the respiration/ decay of vegetation (Pearson and White 1967) and from direct contact with the atmospheric reservoir. Any process (e.g., precipitation, plant growth) that contains carbon will contain a constant input value of ${ }^{14} \mathrm{C}$, so long as it is in equilibrium with the atmosphere. For semiarid locations like the Hanford Site, where evapotranspiration rates may be high, Wallick (1976) reports that the precipitation of $\mathrm{CaCO}_{3}$ and gypsum $\left(\mathrm{CaSO}_{4} \cdot 2 \mathrm{H}_{2} \mathrm{O}\right)$ may occur within the soil horizon. These soil precipitates represent an additional variable input source of ${ }^{14} \mathrm{C}$ (depending on the original time of formation) to later recharging waters.

When the organic material or water becomes isolated from the atmospheric reservoir, the ${ }^{14} \mathrm{C}$ concentration decreases as a function of its radioactive decay. Theoretically, the amount of ${ }^{14} \mathrm{C}$ remaining within a sample can be used to calculate its "age," with the residual ${ }^{14} \mathrm{C}$ content being a function of the time since contact with the atmospheric reservoir was interrupted. Relative (uncorrected) groundwater ages can be calculated using the simple radioactive decay (closed system) equation presented in Matthess et al. (1976):

$$
t=T \ln \left(C_{0} / C\right)
$$

where $\quad T=$ mean life; $T=T^{1 / 2} / \ln 2$

$$
\begin{aligned}
& \mathrm{T}^{1 / 2}=\text { half-life of radioisotope; }{ }^{14} \mathrm{C}=5568 \text { years } \\
& \mathrm{C}_{\mathrm{o}}=\text { initial isotope content at time of recharge } \\
& \mathrm{C}=\text { observed isotope content at time of sampling. }
\end{aligned}
$$

The use of ${ }^{14} \mathrm{C}$ content as an indication of groundwater-residence time or age assumes that no additional sources of either dead carbon or input of ${ }^{14} \mathrm{C}$ occurs to the groundwater. Investigators (e.g., Pearson and Hanshaw 1970) have noted that in many groundwater investigations the addition of carbon to the groundwater system as a result of mineral dilution processes, sulfate reduction, isotopic exchange, and interaquifer groundwater mixing can seriously restrict the use of ${ }^{14} \mathrm{C}$ content information, unless corrections for the extraneous input sources of carbon are accounted for. As noted in Section 3.4.3, the lack of an associated correlation between $\mathrm{HCO}_{3}^{-}$concentration and $\delta^{13} \mathrm{C}$ (see Figure 3.9 [a]) and ${ }^{14} \mathrm{C}$ content (see Figure $3.9[\mathrm{~b}]$ ) and similar $\delta^{13} \mathrm{C}$ range for springs issuing from 
basalts in the Rattlesnake Hills region of the Hanford Site (see Figure 3.8) suggest that dilution through additions of "dead carbon" (i.e., ${ }^{14} \mathrm{C}=0.0 \mathrm{PMC}$ ) may be minimal for groundwater within the upper basalt aquifer system. This suggests that corrections for ${ }^{14} \mathrm{C}$ groundwater age-dating or flow-velocity calculations may not be required.

Figure 3.11 shows the frequency distribution of ${ }^{14} \mathrm{C}$ within (a) the upper basalt aquifer system and (b) the major rivers (i.e., Columbia and Yakima rivers) and springs issuing from basalt formations in the Rattlesnake Hills region of the Hanford Site, respectively. Statistical analysis of ${ }^{14} \mathrm{C}$ values listed in the Appendix for the upper basalt aquifer indicates a mean value of 101.6 $\pm 378.7 \mathrm{PMC}$ and a median value of $27.1 \mathrm{PMC}$, with approximately $75 \%$ of the upper basalt aquifer groundwaters having ${ }^{14} \mathrm{C}$ values of $<40$ PMC. The calculated high mean value for ${ }^{14} \mathrm{C}$ is largely attributed to extremely high ${ }^{14} \mathrm{C}$ values occurring for wells in the vicinity of the 200 East Area (e.g., well 299-E33-12; ${ }^{14} \mathrm{C}=2234 \mathrm{PMC}$ ). Wells identified in Figure 3.11 (a) with elevated ${ }^{14} \mathrm{C}$ values (i.e., $>140 \mathrm{PMC}$ ) are significantly greater than values shown in Figure 3.11 (b) for Columbia River water or for waters from the B Pond disposal facility, which receives Columbia River process-cooling waters. Similar to elevated ${ }^{3} \mathrm{H}$ values for upper basalt aquifer groundwaters discussed in Section 3.5.1, the presence of elevated ${ }^{14} \mathrm{C}$ values for these identified wells is attributable to a component of radioactive waste discharge from disposal facilities in the 200 East Area.

In addition, based on the groundwater-flow pattern indicated in Figure 2.3, groundwater within the upper basalt aquifer flows northward from the indicated natural recharge region in the Rattlesnake Hills-Dry Creek area, discharging within the Gable Mountain-Gable Butte structural area or to the eastsoutheast, ultimately discharging to the Columbia River. Groundwater within the upper basalt aquifer near the Dry Creek natural recharge area has ${ }^{14} \mathrm{C}$ levels of $30 \mathrm{PMC}$ (well 699-25-80). Without significant mixing of groundwater with the overlying unconfined aquifer, groundwater within the upper basalt aquifer would be expected to become depleted in ${ }^{14} \mathrm{C}(<30 \mathrm{PMC})$ in downgradient groundwaterflow locations. Groundwater, therefore, that has ${ }^{14} \mathrm{C}$ values $>30 \mathrm{PMC}$ in the vicinity of the 200 East Area is suspected of having received a component of local recharge water from the overlying unconfined aquifer system. Additional discussion and hydrochemical evidence for aquifer intercommunication in this area is presented in Section 4.1.

Offsite wells located south of the Yakima River exhibit ${ }^{14} \mathrm{C}$ values (61 to $109 \mathrm{PMC}$ ) that are similar to the range shown in Figure 3.11 (b) for river waters and springs and indicate the introduction of recent recharge waters to the aquifer system. This is consistent with previous discussions of other hydrochemical parameters (see Sections 3.1, 3.4.1, and 3.5.1) that indicate a recharge component of Yakima River water to the upper basalt aquifer in this area. 
(a)

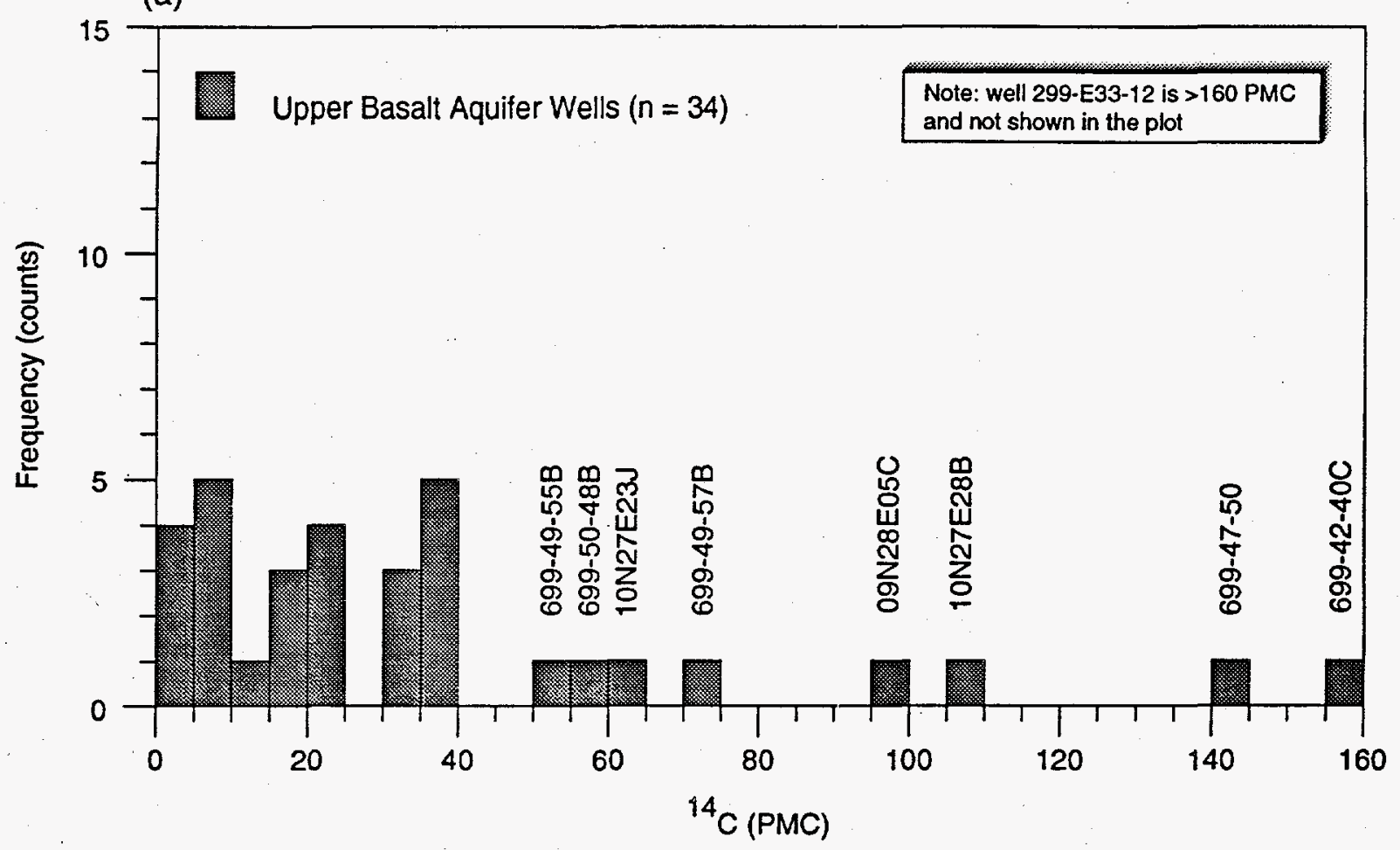

(b)

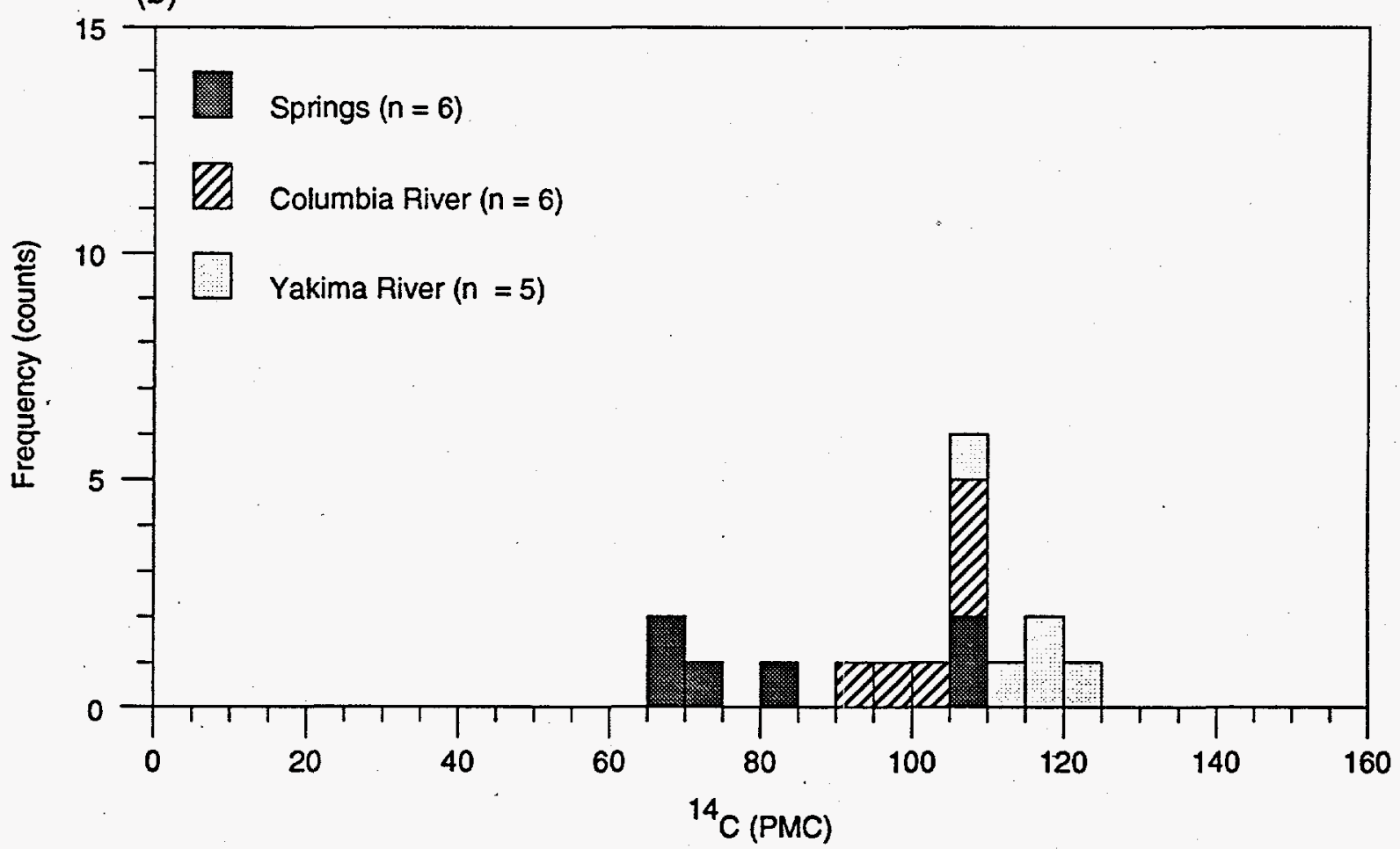

Figure 3.11. Histograms Showing the Frequency Distribution of ${ }^{14} \mathrm{C}$ Within the (a) Upper Basalt Confined Aquifer System and (b) Rivers and Springs on the Hanford Site 


\subsection{3 lodine-129}

Unlike ${ }^{14} \mathrm{C},{ }^{129} \mathrm{I}$ is not a cosmogenic radionuclide produced by nuclear reactions occurring in the atmosphere. In contrast, ${ }^{129} \mathrm{I}$ is mainly produced through man-related activities (e.g., nuclear bomb testing, nuclear fuel rod production, reprocessing, etc.). The fact that ${ }^{129} \mathrm{I}$ is present in natural groundwater systems at extremely low levels makes it a useful tracer for assessing associated manrelated contamination at nuclear facilities. The presence of ${ }^{129} \mathrm{I}$ within the upper basalt aquifer and underlying deeper basalt aquifer systems has been the subject of a number of Hanford Site studies (e.g., IWG 1987; DOE 1988). The presence of elevated ${ }^{129} \mathrm{I}$ in basalt groundwaters has been attributed in these studies to a number of potential sources, including:

- contamination associated with well-construction/drilling practices

- possible emplacement by deep well injection

- downward transference/migration of contaminated unconfined aquifer groundwater to deeper underlying basalt aquifers in the Gable Mountain-Gable Butte structural area.

Early et al. (1988) were able to show that observed values in ${ }^{129} \mathrm{I}$ decreased systematically with depth at several borehole locations within the Gable Butte-Gable Mountain structural area. The depth dependence of ${ }^{129} \mathrm{I}$ concentration levels within the deeper basalt formations supports the hypothesis of a downward migration/transference of contaminated shallow groundwaters in this region.

Examination of the ${ }^{129} \mathrm{I}$ values listed in the Appendix for the upper basalt aquifer indicates considerable variability in analysis results. Values range from below reported laboratory detection limits to a reported high value of 3.7E-02 pCi/L (well 299-E33-12) and a median value of $2.1 \mathrm{E}-04 \mathrm{pCi} / \mathrm{L}$. Six well locations with reported ${ }^{129} \mathrm{I}$ levels $>1.0 \mathrm{E}-04 \mathrm{pCi} / \mathrm{L}$ are all located in the 200 East Area-Gable Mountain region, an area of suspected intercommunication with the overlying contaminated unconfined aquifer. The reported ranges of ${ }^{129} \mathrm{I}$ within the upper basalt aquifer are within the range reported in IWG (1987) for Hanford Site rain (7.0E-05 to 3.0E-02 pCi/L), Hanford Site springs $(2.0 \mathrm{E}-05$ to $5.0 \mathrm{E}-02 \mathrm{pCi} / \mathrm{L})$, and Columbia River $(4.0 \mathrm{E}-06$ to $4.0 \mathrm{E}-04 \mathrm{pCi} / \mathrm{L})$.

The significance of the presence of elevated ${ }^{129}$ I levels within basalt aquifers is a controversial issue in light of the possible contamination of groundwater samples with ${ }^{129} \mathrm{I}$ contained in drilling fluids or associated with well-construction activities. The reader is directed to IWG (1987) and DOE (1988) for a detailed discussion of these implications. 


\subsection{Groundwater-Flow Characteristics}

Available hydrologic head and hydrochemical data indicate that groundwater recharges the upper basalt aquifer system from infiltration of precipitation and surface runoff within the Rattlesnake Hills area, located along the southwestern margin of the Hanford Site, and from artificial recharge associated with irrigation (located principally northeast and east of the Hanford Site) and Hanford Site wastewater disposal (B Pond). Pervasive areal recharge from the overlying unconfined aquifer to the upper basalt aquifer is also expected to occur in the western part of the Hanford Site, where vertical downward head gradient conditions exist between the two aquifer systems (Figure 4.1).

Direct groundwater discharge from the upper basalt confined aquifer system occurs in two identified areas: 1) to the Columbia River along the eastern-southeastern boundary of the Hanford Site and 2) to the overlying and underlying aquifers in the Gable Mountain-Gable Butte structural area north of the 200 East Area. The Columbia River does not form a dominant discharge line-sink for the upper basalt aquifer along its entire course within the northern part of the Hanford Site. This is because of the enhanced vertical permeability afforded by the Gable Mountain-Gable Butte structural area and the significant impact of irrigation recharge on the hydraulic head pattern in the northeastern and eastern regions of the Hanford Site. Pervasive areal discharge from the upper basalt aquifer to the overlying unconfined aquifer is also expected to occur in the eastern part of the Hanford Site, where vertical upward head gradient conditions exist (see Figure 4.1).

\subsection{Evidence for Aquifer Intercommunication/Aquifer Contamination}

Available hydrogeologic, hydraulic head, and hydrochemical data indicate that the principal area of aquifer intercommunication between the upper basalt and unconfined aquifer systems occurs in the area north of the 200 East Area. This area was identified previously by Gephart et al. (1979), DOE (1982, 1988), Graham et al. (1984), and Jensen (1987) as an area where aquifer intercommunication between the upper basalt and unconfined aquifer was likely. Hydraulic intercommunication is attributed to the absence of upper basalt hydrogeologic confining units, structural deformation, and presence of erosional paleostream channels in this region, as discussed in Section 2.1. In addition, groundwater mounding attributed to past and current wastewater disposal (i.e., at B Pond and the decommissioned Gable Mountain Pond) provides a downward driving force from the contaminated unconfined aquifer to the underlying upper basalt confined aquifer system. 


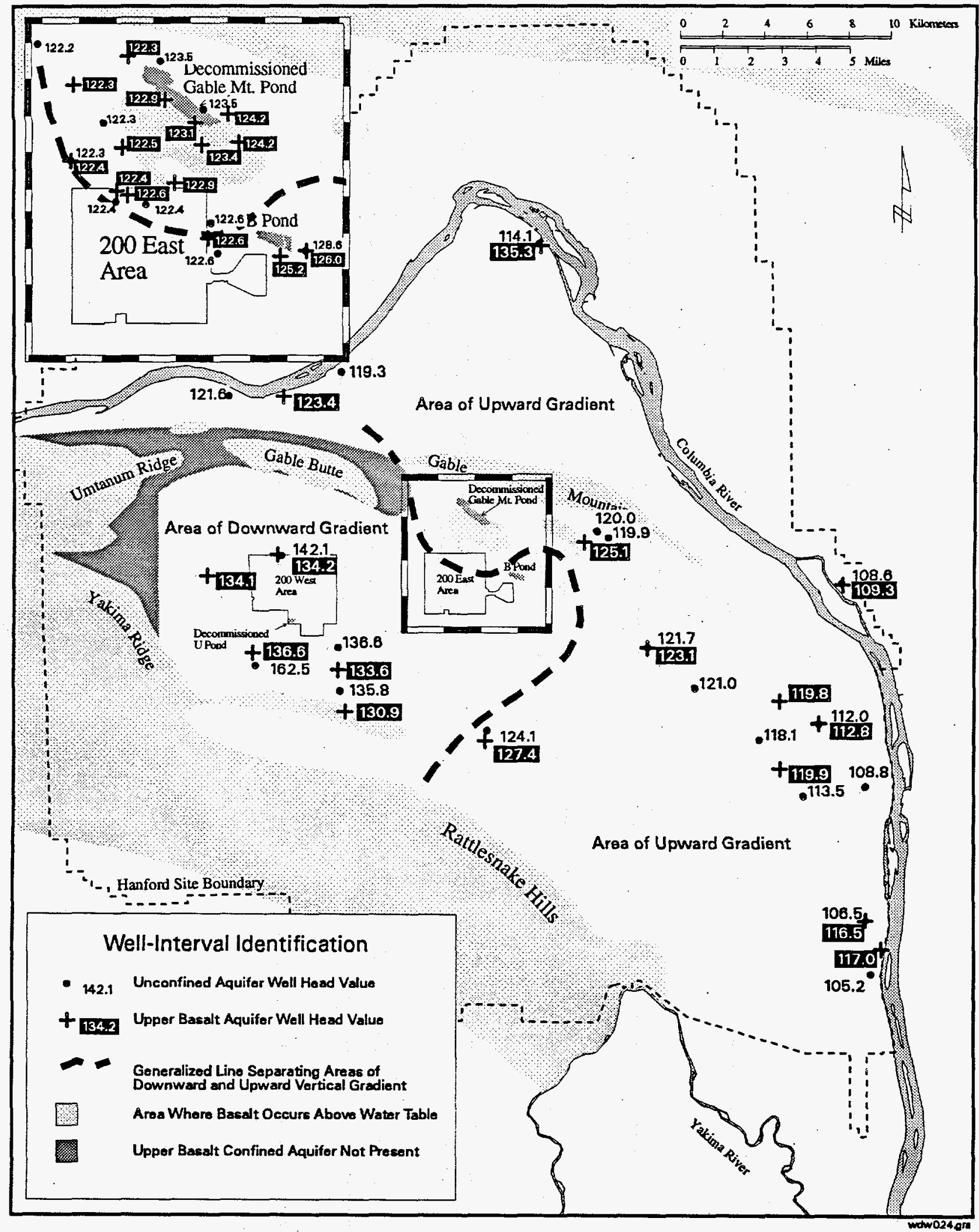

Figure 4.1. Comparison of Observed Hydraulic Heads for the Upper Basalt and Overlying Unconfined Aquifer Systems 
Direct evidence for contamination of the upper basalt confined aquifer from the overlying unconfined aquifer within this region is indicated by the presence of a variety of hydrochemical parameters, including:

- elevated concentration levels of ${ }^{3} \mathrm{H}, \mathrm{NO}_{3}^{-}$, and ${ }^{14} \mathrm{C}$

- change in hydrochemical cation facies from an expected $\mathrm{Na}$ or $\mathrm{Na}-\mathrm{Ca}$ to a $\mathrm{Ca}$ or $\mathrm{Ca}-\mathrm{Mg}$ water type.

Based on the groundwater-flow pattern indicated in Figure 2.3, groundwater within the upper basalt confined aquifer in this region should flow from the indicated natural recharge region in the Rattlesnake Hills-Dry Creek area northward, ultimately discharging within the Gable Mountain-Gable Butte structural area. Without significant mixing of groundwater with the overlying unconfined aquifer, groundwater within the upper basalt confined aquifer would be expected to become depleted in ${ }^{3} \mathrm{H}(<1 \mathrm{TU})$ and ${ }^{14} \mathrm{C}(<30 \mathrm{PMC})$ and have low concentrations of $\mathrm{NO}_{3}^{-}(<1.0 \mathrm{mg} / \mathrm{L})$. Groundwater would also be expected to change in hydrochemical character from a predominant $\mathrm{Ca}-$ to $\mathrm{Ca}, \mathrm{Mg}-\mathrm{HCO}_{3}$ water type near its natural recharge source to an $\mathrm{Na}$ - to $\mathrm{Na}, \mathrm{Ca}-\mathrm{HCO}_{3}$ water type, with increased aquifer-residence time because of the dissolution mechanisms discussed in Section 3.1.

Not all of the hydrochemical indicators are required to be present to indicate intercommunication and the presence of a percentage of unconfined aquifer groundwater within the upper basalt system. This is due, in part, to spatial variation of hydrochemical parameters and contaminant levels within the overlying unconfined aquifer. Table 4.1 lists the identified hydrochemical parameters present within upper basalt aquifer wells in the vicinity of the 200 East Area and Gable Mountain that are indicative of groundwater mixing with the overlying unconfined aquifer. As indicated, most of the upper basalt wells in this region exhibit a degree of groundwater mixing with the overlying unconfined aquifer.

Offsite upper basalt aquifer wells located immediately south of the Yakima River (i.e., wells 09N28E05C, 10N27E23J, 10N27E28B) also exhibit hydrochemical parameters indicative of a recent recharge input of Yakima River water, which is likely associated with agricultural/irrigation practices in this area. Hydrochemical evidence supporting this finding includes similarities in stable isotope $\left({ }^{2} \mathrm{H},{ }^{18} \mathrm{O},{ }^{34} \mathrm{~S}\right)$ and unstable isotope $\left({ }^{3} \mathrm{H},{ }^{14} \mathrm{C}\right)$ composition and elevated $\mathrm{NO}_{3}^{-}$concentration.

It should also be noted that several previous investigators (Graham et al. 1984; Trent 1992) used evidence of low barometric efficiencies (i.e., small associated well water-level response to atmospheric pressure fluctuations) as an indication of intercommunication between the upper basalt confined and unconfined aquifer systems. They reason that low barometric efficiencies (e.g., <0.2) suggest the lack of confinement within the aquifer system. However, as noted by a number of investigators (e.g., Weeks 1979; Rojstaczer and Riley 1988), unconfined aquifers can exhibit large water-level responses 
to barometric fluctuations, with apparent values approaching and, in some cases exceeding, 1.0. Therefore, barometric efficiencies cannot be used as indicators of intercommunication and potential mixing of groundwaters between aquifer systems.

Table 4.1. Presence of Hydrochemical Parameters Within Upper Basalt Wells, Indicating Aquifer Intercommunication and Groundwater Mixing with the Overlying Unconfined Aquifer in the Vicinity of the 200 East Area

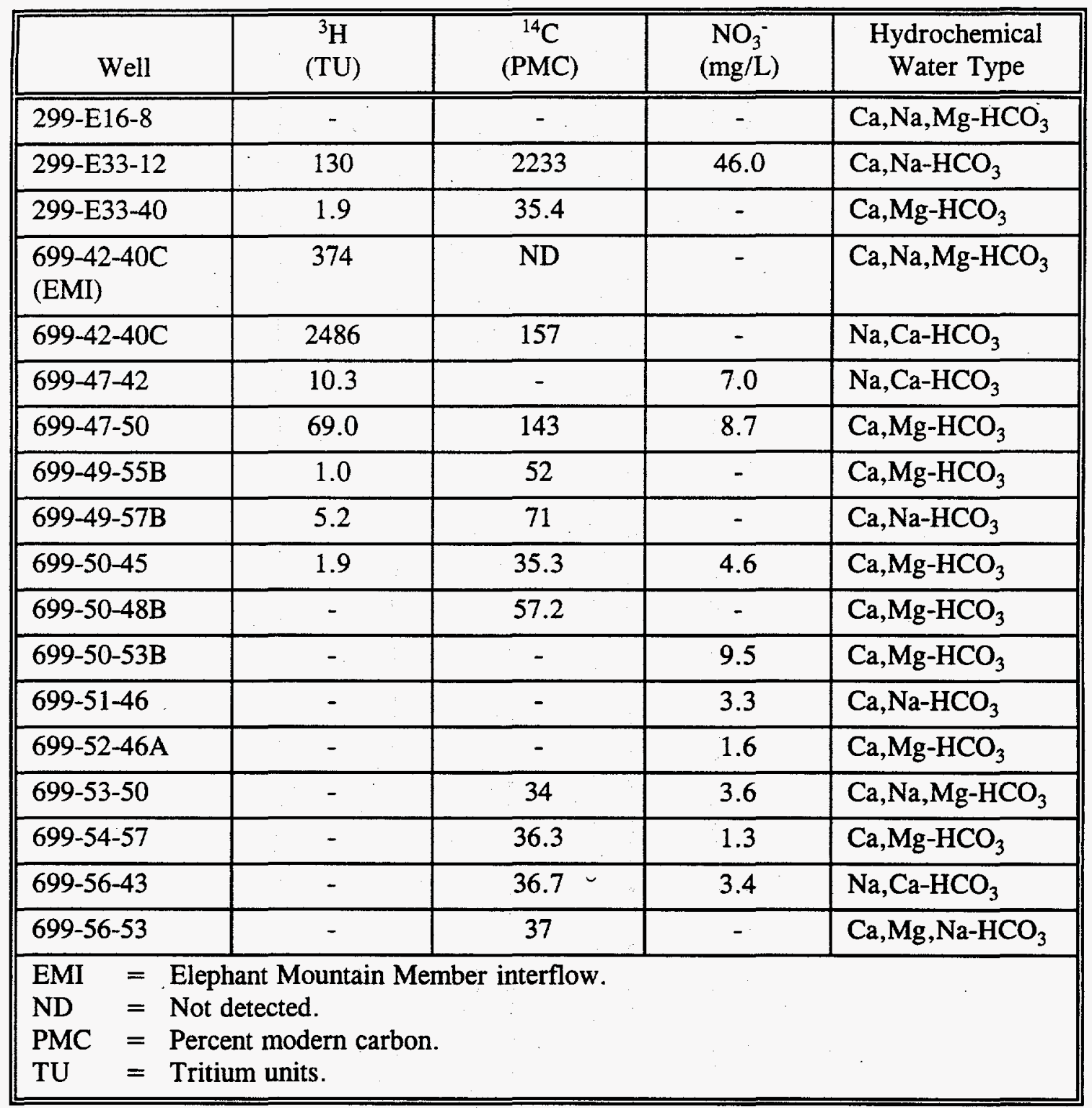




\subsection{Potential for Offsite Migration}

Contamination within the upper basalt confined aquifer system (primarily located in the vicinity of the 200 East Area) has a number of identified potential offsite migration pathways. These potential offsite pathways include:

- across the eastern-southeastern boundary of the Hanford Site

- transference to deeper confined aquifers in the Gable Mountain-Gable Butte structural area

- across the southern boundary of the Hanford Site.

As noted in Sections 2.1 and 4.0, available hydrologic head data indicate that groundwater within the upper basalt confined aquifer system in the southern part of the Hanford Site flows from regions of natural recharge, located in the Rattlesnake Hills-Dry Creek area, ultimately discharging to the Columbia River along the eastern-southeastern site boundary. Areal potentiometric relationships (see Figure 2.3) indicate that the Columbia River forms a dominant line-sink discharge area for the upper basalt aquifer in this region. Any contamination within the upper basalt aquifer along this potential flow path would discharge to the overlying unconfined aquifer (in the vicinity of the Columbia River) and from the unconfined aquifer to the Columbia River. Existing high hydraulic head conditions in the region east of the Columbia River (attributed to effects of irrigation-induced recharge) also preclude the further offsite migration of contaminants to regions in this flow-path direction.

Travel-time/groundwater flow-velocity calculations for upper basalt aquifer groundwater along this potential offsite flow path can be calculated, based on areal hydraulic and hydrochemical/isotopic information. Information provided from widely spaced wells, located along the groundwater-flow path (wells 699-17-47 and 699-S16-E14), were used in the groundwater flow-velocity calculation.

Groundwater flow-velocity calculations using hydraulic property considerations are based on the following relationship, provided in Lohman (1972):

$$
v=\frac{K}{\theta}(\mathrm{dh} / \mathrm{dl})
$$

where $\quad \mathrm{v}=$ groundwater pore-flow velocity $(\mathrm{L} / \mathrm{T})$

$\mathrm{K}=$ lateral hydraulic conductivity $(\mathrm{L} / \mathrm{T})$

$\Theta=$ effective porosity (dimensionless)

$\mathrm{dh} / \mathrm{dl}=$ lateral hydraulic head gradient (dimensionless). 
Given the following information for wells 699-17-47 and 699-S16-E14 (both completed in the Rattlesnake Ridge interbed): lateral distance $=21,314 \mathrm{~m}$, average lateral hydraulic conductivity $=$ $1.64 \mathrm{~m} / \mathrm{d}$ (Spane and Vermeul 1994), lateral hydraulic head gradient $=0.00049$ (Spane and Raymond 1993), and an assumed effective porosity $=0.2$ as input into Equation (4.1), yields a calculated groundwater-flow velocity of $1.46 \mathrm{~m} / \mathrm{yr}$. As indicated in Equation (4.1), the calculated flow velocity is directly proportional to the reciprocal of the effective porosity. Because the effective porosity is an assumed rather than measured value, a degree of uncertainty in the flow-velocity estimate is indicated. Utilizing a range for effective porosity for silts and sands of the Rattlesnake Ridge interbed of 0.1 to 0.3 provides a range for calculated groundwater-flow velocity between 0.7 and $2.9 \mathrm{~m} / \mathrm{yr}$.

The uncertainty in the flow-velocity estimate, associated with knowing the effective porosity and hydraulic properties required in Equation (4.1), is eliminated when direct hydrochemical/isotopic agedating methods are employed. For this calculation method, the flow-velocity estimate is obtained by directly comparing computed groundwater ages or residence times for well locations along the prescribed flow path. As discussed in Section $3.5 .2,{ }^{14} \mathrm{C}$ data can be utilized for this purpose. Using ${ }^{14} \mathrm{C}$ values listed for wells 699-17-47 (16.2 PMC) and 699-S16-E14 (4.9 PMC) in Equation (3.4) yields calculated relative groundwater ages of 14,620 and 24,225 years, respectively. The lateral distance $(21,314 \mathrm{~m})$ between the two sites, divided by the difference in the groundwater ages (9605 years), provides an estimated groundwater-flow velocity of $2.2 \mathrm{~m} / \mathrm{yr}$, which is in close agreement with the groundwater velocity range calculation $(0.7$ to $2.9 \mathrm{~m} / \mathrm{yr})$, based on hydraulic property information. It should be noted that the ${ }^{14} \mathrm{C}$-based groundwater ages used in the flow-velocity calculation are uncorrected for dilutionary or exchange sources of carbon within the groundwater-flow system. However; as discussed in Sections 3.4.3 and 3.5.2, these effects are probably small and would be expected to be uniform over short distances within the upper basalt confined aquifer system.

It can be concluded, therefore, that the potential for offsite migration across the easternsoutheastern boundary of the Hanford Site is considered low because of the low lateral flow velocities for groundwater along this flow path in the upper basalt system, the indication that the Columbia River forms a dominant line-sink discharge area for the aquifer system in this region, and the presence of high hydraulic head conditions to the east of the river. Any contamination within this region of the upper basalt confined aquifer system is expected to discharge to the overlying unconfined aquifer and eventually to the Columbia River at a very slow rate.

The potential for offsite migration may also occur through transference of groundwater from the upper basalt aquifer to the deeper confined aquifers in the region north of the 200 East Area, in the Gable Mountain-Gable Butte structural area. Early et al. (1988) utilized the vertical depth/concentration profiles for ${ }^{3} \mathrm{H},{ }^{14} \mathrm{C}$, and ${ }^{129} \mathrm{I}$ at two well locations in this area. Based on these radioisotopic results, downward groundwater-flow rates were estimated to range between 4.6 to $5.8 \mathrm{~m} / \mathrm{yr}$. Groundwater in this region flows downward from the upper basalt aquifer system and the underlying Saddle 
Mountains Basalt to deeper aquifers within the Wanapum Basalt. Aquifers within the Wanapum Basalt are regionally important offsite sources of groundwater for agricultural and domestic use. The degree of contamination within the underlying Wanapum Basalt aquifers is largely unknown. However, because of the high hydraulic conductivity values reported for some Wanapum Basalt interflow aquifers, their deep hydrogeologic setting, and offsite use, a potential exists for offsite migration of contaminants through this pathway. As noted by Early et al. (1988), however, any contamination within Wanapum Basalt aquifers would be significantly reduced by dilution within these units prior to migrating offsite.

The potential also exists for offsite migration within the upper basalt system across the southern boundary of the Hanford Site. This is based on the assumption that the Yakima River does not form a dominant line-sink discharge area for the upper basalt system. The possibility for offsite migration along this potential flow path is highly uncertain because of the paucity of hydrogeologic, hydraulic property, and hydrochemical information for the upper basalt system in this area. However, the presence of offsite municipal, agricultural, and domestic users of groundwater from the upper basalt aquifer south of the Hanford Site and forecasted development in this area warrant further investigation of this potential contaminant pathway. 


\subsection{References}

Craig, H. 1961. "Isotopic Variations in Meteoric Waters." Science 133:1702-1703.

Davis, S. N. 1989. Use of Isotope Techniques in the Study of the Hydrogeology of Fractured Rock Aquifers. Panel Proceedings Series, International Atomic Energy Agency, Vienna, Austria, pp. 1-4.

Dirkes, R. L. 1994. "Surface-Water Surveillance." In Hanford Site Environmental Report for Calendar Year 1993, R. L. Dirkes, R. W. Hanf, and R. K. Woodruff (eds.), pp. 119-136. PNL-9823, Pacific Northwest Laboratory, Richland, Washington.

DOE (U.S. Department of Energy). 1982. Site Characterization Report for the Basalt Waste Isolation Project. DOE/RL 82-3, 3 Vols., U.S. Department of Energy, Richland, Washington.

DOE (U.S. Department of Energy). 1988. Consultation Drafi, Site Characterization Plan, Reference Repository Location, Hanford Site, Washington. DOE/RW-0164, Vols. 1 and 2, U.S. Department of Energy, Washington, D.C.

Dresel, P. E. 1994. "Ground-Water Protection and Monitoring Program." In Hanford Site Environmental Report for Calendar Year 1993, R. L. Dirkes, R. W. Hanf, and R. K. Woodruff (eds.), pp. 173-217. PNL-9823, Pacific Northwest Laboratory, Richland, Washington.

Dresel, P. E., S. P. Luttrell, J. C. Evans, W. D. Webber, P. D. Thorne, M. A. Chamness, B. M. Gillespie, B. E. Opitz, J. T. Rieger, and J. K. Merz. 1994. Hanford Site Ground-Water Monitoring for 1993. PNL-10082, Pacific Northwest Laboratory, Richland, Washington.

Early, T. O., G. D. Spice, and M. D. Mitchell. 1986. A Hydrochemical Data Base for the Hanford Site, Washington. SD-BWI-DP-061, Rockwell Hanford Operations, Richland, Washington.

Early, T. O., S. H. Hall, and V. G. Johnson. 1988. "Tritium, Carbon-14, and Iodine-129 as Indicators for Localized Vertical Recharge Along an Anticline in the Columbia River Basalts Using a Decay-Corrected Mixing Model." In Proceedings of the Ground Water Geochemistry Conference, February 16-18, 1988, Denver, Colorado, pp. 597-620. National Water Well Association, Dublin, Ohio.

Fontes, J. C. 1980. "Environmental Isotopes in Groundwater Hydrology." In Handbook of Environmental Isotope Geochemistry, Vol. I - The Terrestrial Environment, P. Fritz and J. C. Fontes (eds.), Elsevier, New York, 545 p.

Fritz, P., and J. C. Fontes. 1980. "Introduction - Standards." In Handbook of Environmental Isotope Geochemistry, Vol. I - The Terrestrial Environment, P. Fritz and J. C. Fontes (eds.), Elsevier, New York, 545 p. 
Gat, J. R., and Y. Tzur. 1967. "Modification of the Isotopic Composition of Rainwater by Processes Which Occur Before Groundwater Recharge." In Isotopes in Hydrology. Proceedings Series, International Atomic Energy Agency, Vienna, Austria

Gephart, R. E., F. A. Spane, Jr., L. S. Leonhart, D. A. Palombo, and S. R. Strait. 1979. "Pasco Basin Hydrology." In Hydrologic Studies Within the Columbia Plateau, Washington: An Integration of Current Knowledge, pp. III-1 to III-236. RHO-BWI-ST-5, Rockwell Hanford Operations, Richland, Washington.

Graham, D. L. 1983. Stable Isotopic Composition of Precipitation From the Rattlesnake Hills Area of South-Central Washington State. RHO-BW-ST-44P, Rockwell Hanford Operations, Richland, Washington.

Graham, D. L. 1984. An Assessment of Drilling Fluid Tracers Used to Monitor Borehole Development for Hydrochemical Sampling. RHO-BW-ST-61P, Rockwell Hanford Operations, Richland, Washington.

Graham, M. J., G. V. Last, and K. R. Fecht. 1984. An Assessment of Aquifer Intercommunication in the B Pond-Gable Mountain Pond Area of the Hanford Site. RHO-RE-ST-12 P, Rockwell Hanford Operations, Richland, Washington.

IWG (Intercontractor Working Group). 1987. Data Compilation of Iodine-129 in Hanford Groundwater. WHC-EP-0037, Westinghouse Hanford Company, Richland, Washington.

Jensen, E. J. 1987. An Evaluation of Aquifer Intercommunication Between the Unconfined and Rattlesnake Ridge Aquifers on the Hanford Site. PNL-6313, Pacific Northwest Laboratory, Richland, Washington.

Lohman, S. W. 1972. Ground-Water Hydraulics. Professional Paper 708, U.S. Geological Survey, Washington, D.C.

Matthess, G., K. O. Münnich, and C. Sonntag. 1976. "Practical Problems of Groundwater Model Ages for Groundwater Protection Studies." In Interpretation of Environmental Isotope and Hydrochemical Data in Groundwater Hydrology, Proceedings of the International Atomic Energy Agency, Vienna, Austria, January 27-31, 1975, pp. 185-194.

Mook, W. G. 1980. "Carbon-14 in Hydrogeological Studies." In Handbook of Environmental Isotope Geochemistry, Vol. 1 - The Terrestrial Environment, P. Fritz and J. C. Fontes (eds.), Elsevier, New York, 545 p.

Newcomb, R. C. 1969. Effect of Tectonic Structure on the Occurrence of Groundwater in the Basalt of the Columbia River Group of the Dalles Area, Oregon and Washington. Professional Paper 383-C, U.S. Geological Survey, Washington, D.C., pp. C1-C33. 
Newcomb, R. C. 1972. Quality of the Ground Water in Basalt of the Columbia River Group, Washington, Oregon, and Idaho. Water-Supply Paper 1999-N, U.S. Geological Survey, Washington, D.C.

Newcomer, D. R. 1990. Evaluation of Hanford Site Water-Table Changes - 1980 to 1990. PNL-7498, Pacific Northwest Laboratory, Richland, Washington.

Papadopulos, I. S., J. D. Bredehoeft, and H. H. Cooper, Jr. 1973. "On the Analysis of Slug Test Data." Water Resour. Res. 9(4):1087-1089.

Pearson, F. J., Jr., and B. B. Hanshaw. 1970. "Sources of Dissolved Carbonate Species in Groundwater and Their Effects on Carbon-14 Dating." In Isotope Hydrology 1970, Proceedings of the International Atomic Energy Agency, Vienna, Austria, March 9-13, 1970, pp. 271-286.

Pearson, F. J., Jr., and C. T. Rightmire. 1980. "Sulphur and Oxygen Isotopes in Aqueous Sulfur Compounds." In Handbook of Environmental Isotope Geochemistry, Vol. 1 - The Terrestrial Environment, P. Fritz and J. C. Fontes (eds.), Elsevier, New York, 545 p.

Pearson, F. J., Jr., and D. E. White. 1967. "Carbon 14 Ages and Flow Rates of Water in Carrizo Sand, Atascosa County, Texas." Water Resour. Res. 3:251-261.

Reidel, S. P., and K. R. Fecht. 1981. "Wanapum and Saddle Mountains Basalts of the Cold Creek Syncline Area." In Subsurface Geology of the Cold Creek Syncline, C. W. Myers and S. M. Price (eds.), pp. 3-1 to 3-45. RHO-BWI-ST-14, Rockwell Hanford Operations, Richland, Washington.

Rightmire, C. T., F. J. Pearson, W. Back, R. O. Rye, and B. B. Hanshaw. 1974. Distribution of Sulfur Isotopes of Sulfate in Groundwaters from the Principal Artesian Aquifer of Florida and the Edwards Aquifer of Texas, U.S.A. International Atomic Energy Agency, Vienna, Austria, pp. 191-201.

Rojstaczer, S., and F. S. Riley. 1988. "Response of the Water Level in a Well to Earth Tides and Atmospheric Loading Under Unconfined Conditions." Water Resour. Res. 26(8):1803-1817.

Spane, F. A., Jr. 1981. Hydrogeologic Properties and Hydrochemistry for the Levey Interbed at Well 699-S11-E12A. RHO-BWI-LD-27, Rockwell Hanford Operations, Richland, Washington

Spane, F. A., Jr. 1982. "Hydrologic Studies Within the Pasco Basin." In Proceedings of the 1982 National Waste Terminal Storage Program Information Meeting, pp. 23-28. DOE/NWTS-30, U.S. Department of Energy, Richland, Washington.

Spane, F. A., Jr. 1987. Fresh-Water Potentiometric Map and Inferred Flow Direction of Ground Water Within the Mabton Interbed, Hanford Site, Washington State -- January 1987. SD-BWI-TI-335, Rockwell Hanford Operations, Richland, Washington.

Spane, F. A., Jr. 1992. Hydraulic Test Results for Savage Island Wells: 699-32-22B, 699-42-E9A, and 699-42-E9B. PNL-8173, Pacific Northwest Laboratory, Richland, Washington. 
Spane, F. A., Jr., and R. G. Raymond. 1993. Preliminary Potentiometric Map and Flow Dynamic Characteristics for the Upper-Basalt Confined Aquifer System. PNL-8869, Pacific Northwest Laboratory, Richland, Washington.

Spane, F. A., Jr., and V. R. Vermeul. 1994. Summary and Evaluation of Hydraulic Property Data Available for the Hanford Site Upper Basalt Confined Aquifer System. PNL-10158, Pacific Northwest Laboratory, Richland, Washington.

Spane, F. A., Jr., M. D. Howland, and S. R. Strait. 1980. Hydrogeologic Properties and GroundWater Chemistry of the Rattlesnake Ridge Interbed at Well 699-25-80 (DB-14), Hanford Site.

RHO-LD-67, Rockwell Hanford Operations, Richland, Washington.

Spane, F. A., Jr., D. L. Graham, and R. W. Bryce. 1982. Hydrochemical and Isotopic Content of Basalt Ground Waters Beneath the Hanford Site, Washington. RHO-BW-SA-190 P, Rockwell Hanford Operations, Richland, Washington; paper presented at the Geological Society of America Meeting, Bozeman, Montana, May 7-8, 1982.

Steinkampf, W. C. 1989. Water-Quality Characteristics of the Columbia Plateau Regional Aquifer System in Parts of Washington, Oregon, and Idaho. Water-Resources Investigations Report 87-4242, U.S. Geological Survey, Washington, D.C., 37 p.

Strait, S. R., and R. B. Mercer. 1987. Hydraulic Property Data from Selected Test Zones on the Hanford Site. SD-BWI-DP-051, Rev. 2, Rockwell Hanford Operations, Richland, Washington.

Swanson, L. C., and B. A. Leventhal. 1984. Water-Level Data and Borehole Description for Monitoring Wells Used by the Basalt Waste Isolation Project. SD-BWI-DP-042, Rev. 0, Rockwell Hanford Operations, Richland, Washington.

Trent, S. J. 1992. Hydrogeologic Model for the 200 East Groundwater Aggregate Area. WHC-SD-EN-TI-019, Rev. 0, Westinghouse Hanford Company, Richland, Washington.

van der Kamp, G. 1976. "Determining Aquifer Transmissivity by Means of Well Response Tests: The Underdamped Case." Water Resour. Res. 12(1):71-77.

Wallick, E. I. 1976. "Isotopic and Chemical Considerations in Radiocarbon Dating of Groundwater Within the Semi-Arid Tucson Basin, Arizona." In Interpretation of Environmental Isotope and Hydrochemical Data in Groundwater Hydrology, Proceedings of the International Atomic Energy Agency, Vienna, Austria, January 27-31, 1975, pp. 195-212.

Weeks, E. P. 1979. "Barometric Fluctuations in Wells Tapping Deep Unconfined Aquifers." Water Resour. Res. 15(5):1167-1176.

Whiteman, K. J., J. J. Vaccaro, J. B. Gonthier, and H. H. Bauer. 1994. The Hydrogeologic Framework and Geochemistry of the Columbia Plateau Aquifer System, Washington, Oregon, and Idaho. Professional Paper 1413-B, U.S. Geological Survey, Washington, D.C. 


\section{Appendix}

Hydrochemical Data Summary Tables 


\section{Appendix}

\section{Hydrochemical Data Summary Tables}

The hydrochemical data listed in this Appendix represent results for individual upper basalt confined aquifer system groundwater samples that were selected from the Hanford Environmental Information System (HEIS). Criteria used in selecting the groundwater sample analyses utilized in this report are discussed in Section 3.0.

The listed hydrochemical results were performed by a number of laboratories using various analytical methods. Most major ion analyses were performed by ion chromatograph and inductively coupled plasma methods. Typical detection levels for major ions by these methods are well below concentrations found in natural groundwaters. Typical detection limits for trace metals range from $<10$ to $100 \mu \mathrm{g} / \mathrm{L}$. The concentration of trace metals for many upper basalt confined aquifer system groundwaters is near or below the detection levels of methods used.

Tritium is identified by its low-energy beta emission. Analytical methods include scintillation, low-level gas-proportional, and enrichment-counting techniques. The detection limits for tritium data reported in HEIS vary from $>500$ to as low as $0.3 \mathrm{pCi} / \mathrm{L}$. Many of the tritium values reported in HEIS prior to 1984 do not have an associated counting error. Concentrations of measured constituents that are below the detection limit are indicated in Tables A.1 through A.3 as undetected (U).

Where possible, major ion, trace metal, and isotope concentrations are reported for the most recent individual sampling event for which the detection limit of analytical methods used was adequate for the various constituents. A complete set of analyses for individual groundwater samples was not available for all wells/intervals. For wells/intervals without complete analyses, concentration values for the missing specific constituents (i.e., alkalinity, silica, trace metals, and stable and unstable isotopes) were selected from results from other sampling events for the wells/intervals that were collected as near to the same data as possible. 
Table A.1. Summary Table of Major Inorganics

\begin{tabular}{|c|c|c|c|c|c|c|c|c|c|c|c|c|c|c|c|c|c|c|}
\hline \multirow[b]{2}{*}{ Woll } & \multirow{2}{*}{$\begin{array}{c}\text { Principal } \\
\text { Unit }\end{array}$} & \multirow[b]{2}{*}{ Date } & \multirow{2}{*}{$\begin{array}{c}\text { Temp } \\
\text { OC }\end{array}$} & \multirow[b]{2}{*}{$\mathrm{pH}$} & \multirow{2}{*}{\begin{tabular}{|c|} 
Conduct \\
umhos $/ \mathrm{cm}$
\end{tabular}} & \multirow{2}{*}{$\begin{array}{c}\text { TDS } \\
\text { (mg/L) }\end{array}$} & \multirow[b]{2}{*}{ Si mghl } & \multicolumn{5}{|c|}{ Anions $(\mathrm{mg} / \mathrm{L})$} & \multicolumn{4}{|c|}{ Cations (mg/L) } & \multirow{2}{*}{$\begin{array}{l}\text { Balance } \\
\text { \%error }\end{array}$} & \multirow{2}{*}{$\begin{array}{c}\text { Separate } \\
\text { Sample }\end{array}$} \\
\hline & & & & & & & & Alk & C & $F$ & SO4 & $\mathrm{NO} 3$ & $\mathrm{Na}$ & $k$ & $\mathrm{Ca}$ & $\mathrm{Mg}$ & & \\
\hline O9N28E05C & USMB & 15-Aug-94 & 17.7 & 7.4 & 438 & 323 & & 180.0 & 10.0 & 0.7 & 35.0 & 4.9 & 20.0 & 6.3 & 50.0 & 16.0 & $1 \%$ & \\
\hline 10N27E23J & USMB & 15-Aug-94 & 17.3 & 7.6 & 608 & 420 & & 180.0 & 33.0 & 1.2 & 86.0 & 0.0 & 35.0 & 9.7 & 48.0 & 27.0 & $0 \%$ & \\
\hline 10N27E28B & USMB & 15-Aug-94 & 17.6 & 7.5 & 671 & 468 & & 240.0 & 50.0 & 1.1 & 31.0 & 9.8 & 38.0 & 6.6 & 66.0 & 25.0 & $1 \%$ & \\
\hline 12N28E23H & USMB & 15-Aug-94 & 18.0 & 7.8 & 393 & 289 & & 170.0 & 18.0 & 1.3 & 11.0 & 0.0 & 63.0 & 11.0 & 12.0 & 3.1 & $-4 \%$ & \\
\hline 199-H4-2 & RRI & 5-Aug-94 & 21.9 & 9.0 & 232 & 166 & & 70.0 & 8.8 & 0.3 & 35.0 & 0.7 & 26.0 & 8.7 & 11.0 & 5.2 & $-2 \%$ & \\
\hline 299-E16-1 & EMI & 14Jul-82 & 23.2 & 8.3 & 340 & 259 & 32 & 145.0 & 1.0 & 0.6 & 35.0 & & 31.0 & 10.2 & 26.0 & 9.9 & $0 \%$ & \\
\hline 299-E26-8 & RRI & 28-Jun-93 & 18.2 & 8.8 & 303 & 203 & 37 & 100.0 & 8.4 & 0.6 & 33.0 & 0.6 & 20.0 & 9.7 & 22.0 & 8.5 & $-1 \%$ & $\mathrm{Si}$ \\
\hline 299-E33-12 & RRI & 26-May-93 & 20.0 & 7.9 & 319 & 242 & 27 & 100.0 & 8.7 & 0.4 & 17.0 & 46.0 & 24.0 & 8.2 & 29.0 & 8.4 & $0 \%$ & $\mathrm{Si}$ \\
\hline 299-E33-40 & RRI & 23-Jun-93 & 18.9 & 7.5 & 272 & 183 & 24 & 90.0 & 3.9 & 0.4 & 33.0 & 0.2 & 13.0 & 7.0 & 28.0 & 7.7 & $3 \%$ & $\mathrm{Si}$ \\
\hline $399-5-2$ & USMB & 1-Sep-94 & 19.0 & 8.2 & 321 & 275 & & 180.0 & 9.0 & 1.9 & 0.0 & 0.2 & 56.0 & 8.8 & 14.0 & 4.8 & $-3 \%$ & \\
\hline 699-S11-E12AP & LEVEY & 12-Aug-94 & 16.9 & 8.1 & 373 & 263 & 28 & 170.0 & 14.0 & 1.2 & 0.0 & 0.0 & 45.0 & 6.9 & 20.0 & 5.4 & $-4 \%$ & $\mathrm{Si}$ \\
\hline 699-S16-E14 & LEVEY & $4 \sqrt{ }$ an-80 & 17.0 & 7.8 & 364 & 267 & 23 & 167.5 & 11.2 & 1.2 & & & 60.3 & 12.6 & 10.5 & 3.8 & $1 \%$ & \\
\hline 699-S16-E14 & RRI & 23-Jan-80 & 18.1 & 8.3 & 301 & 249 & 26 & 157.9 & 8.1 & 1.0 & & & 58.2 & 12.6 & 9.0 & 2.5 & $1 \%$ & \\
\hline $699-17-47$ & EMI & 13-Jun-78 & & 8.2 & 320 & 265 & 40 & 159.0 & 4.1 & 0.4 & 18.9 & & 21.5 & 9.1 & 37.3 & 14.4 & $6 \%$ & \\
\hline $699-17-47$ & RRI & 26-Jun-78 & & 8.0 & 302 & 241 & 41 & 150.0 & 3.8 & 0.4 & 7.9 & & 36.4 & 9.1 & 23.3 & 9.9 & $7 \%$ & \\
\hline $699-25-80$ & RRI & 10-Sep-78 & & 8.4 & 388 & 261 & 31 & 130.4 & 5.4 & 0.3 & 38.6 & 5.5 & 17.0 & 6.4 & 42.0 & 15.8 & $8 \%$ & \\
\hline 699-32-22B & EMI & 1-Jun-91 & 25.1 & 8.2 & 355 & 263 & 32 & 142.0 & 9.9 & 1.3 & 23.5 & & 63.7 & 8.7 & 11.4 & 2.1 & $1 \%$ & \\
\hline 699-42-E9B & RRI & 1. Jul-94 & 19.8 & 8.4 & 400 & 295 & & 130.0 & 24.0 & 1.7 & 40.0 & & 82.0 & 9.8 & 5.9 & 1.4 & $0 \%$ & \\
\hline $699-42-40 \mathrm{C}$ & EMI & 16-Apr-82 & 18.0 & 7.7 & 425 & 221 & 23 & 128.0 & 5.1 & 0.9 & 18.0 & & 24.6 & 6.4 & 26.6 & 11.8 & $6 \%$ & \\
\hline $699-42-40 \mathrm{C}$ & RRI & 25-May-93 & 16.0 & 8.9 & 303 & 225 & 34 & 120.0 & 6.9 & 0.7 & 25.0 & 1.0 & 39.0 & 14.0 & 13.0 & 5.8 & $0 \%$ & \\
\hline $699-42-42 A$ & RRI & 13-Jul-93 & 18.2 & 8.6 & 257 & 192 & & 120.0 & 5.4 & 0.7 & 4.8 & 0.1 & 29.0 & 11.0 & 17.0 & 4.0 & $1 \%$ & Anions \\
\hline $699-47-42$ & RRI & 26-Apr-79 & 17.4 & 7.0 & 318 & 229 & 25 & 98.4 & 7.7 & 0.3 & 37.1 & 7.0 & 44.4 & 10.4 & 18.9 & 4.9 & $7 \%$ & \\
\hline $699-47-50$ & RRI & 26-May-93 & 18.4 & 7.3 & 489 & 315 & 20 & 100.0 & 26.0 & 0.8 & 88.0 & 8.7 & 20.0 & 7.1 & 50.0 & 14.0 & $-1 \%$ & $\mathrm{Si}$ \\
\hline $699-49-55 B$ & RRI & 26-May-93 & 18.9 & 8.0 & 270 & 186 & 25 & 110.0 & 8.8 & 0.3 & 14.0 & 1.0 & 10.0 & 6.0 & 27.0 & 8.9 & $-2 \%$ & $\mathrm{Si}$ \\
\hline $699-49-57 \mathrm{~B}$ & RRI & 25-May-93 & 17.7 & 7.7 & 301 & 225 & 19 & 140.0 & 8.3 & 0.7 & 13.0 & 0.9 & 21.0 & 3.1 & 31.0 & 6.9 & $-4 \%$ & $\mathrm{Si}$ \\
\hline $699-50-45$ & RPI & $14 \sqrt{ } \mathrm{ul} \cdot 94$ & 18.2 & 8.0 & 334 & 225 & 27 & 110.0 & 21.0 & 0.8 & 23.0 & 4.6 & 17.0 & 5.4 & 32.0 & 11.0 & $.0 \%$ & $\mathrm{Si}$ \\
\hline 699-50-48B & RRI & 7-Jul-94 & 19.0 & 7.7 & 318 & 217 & 31 & 100.0 & 28.0 & 0.8 & 33.0 & 0.3 & 13.0 & 3.5 & 26.0 & 12.0 & $-9 \%$ & $\mathrm{Si}$ \\
\hline $699-50-53 B$ & RRI & 1-Aug-94 & 18.0 & 8.1 & 322 & 261 & 28 & 120.0 & 9.6 & 0.6 & 50.0 & 9.5 & 12.0 & 7.6 & 41.0 & 11.0 & $-3 \%$ & $\mathrm{Si}$ \\
\hline $699-51-46$ & RRI & 15-Jul-94 & 17.4 & 8.3 & 317 & 212 & 32 & 100.0 & 14.0 & 0.7 & 25.0 & 3.3 & 22.0 & 9.2 & 33.0 & 4.4 & $3 \%$ & $\mathrm{Si}$ \\
\hline $699-52-46 A$ & RRI & 29-Jun-94 & 18.3 & 7.7 & 315 & 221 & 37 & 110.0 & 25.0 & 0.6 & 16.0 & 1.6 & 17.0 & 7.2 & 34.0 & 9.5 & $2 \%$ & Si \\
\hline $699-52-48$ & RAI & 1.Jul-94 & 18.1 & 8.3 & 338 & 256 & 28 & 160.0 & 5.0 & 1.5 & 9.5 & 0.1 & 59.0 & 6.0 & 12.0 & 2.5 & $.1 \%$ & $\mathrm{Si}$ \\
\hline 699-53-50 & RRI & 1-Aug-94 & 17.8 & 8.0 & 291 & 225 & 33 & 120.0 & 18.0 & 0.6 & 17.0 & 3.6 & 20.0 & 6.5 & 30.0 & 9.1 & $-1 \%$ & $\mathrm{Si}$ \\
\hline 699-54-57 & RRI & 26-May-93 & 18.1 & 8.4 & 317 & 211 & 34 & 120.0 & 14.0 & 0.4 & 16.0 & 1.3 & 13.0 & 7.0 & 30.0 & 9.7 & $-2 \%$ & $\mathrm{Si}$ \\
\hline $699-56-43$ & USMB & 7-Jul-94 & 19.5 & 6.4 & 271 & 214 & & 100.0 & 22.0 & 0.8 & 11.0 & 3.4 & 33.0 & 11.0 & 27.0 & 5.3 & $9 \%$ & \\
\hline $699-56-53$ & RRI & 18-Jul-94 & 18.5 & 7.7 & 353 & 241 & 19 & 140.0 & 25.0 & 0.6 & 6.6 & 0.8 & 17.0 & 5.9 & 33.0 & 12.0 & $-2 \%$ & $\mathrm{Si}$ \\
\hline 699-84-34B & EMI & 22-Jan-80 & 18.9 & 8.4 & & 247 & 28 & 132.4 & 5.9 & 1.1 & 28.1 & & 58.5 & 10.0 & 9.6 & 1.9 & $-0 \%$ & \\
\hline 699-84-34B & RRI & 18-Jan-80 & 16.7 & 8.1 & 258 & 210 & 32 & 109.3 & 6.5 & 0.8 & 23.5 & & 48.8 & 13.1 & 6.5 & 1.4 & $0 \%$ & \\
\hline
\end{tabular}

EMI = Elophant Mountain Member Intertiow

LEVEY = Lovey Intorbod

RRI
USMB $=$ Rattlosnake Ridgo Interbod
Uppor Saddlo Mountains Basalt 
Table A.2. Summary Table of Trace Elements

\begin{tabular}{|c|c|c|c|c|c|c|c|c|c|c|c|c|c|c|c|c|c|c|}
\hline \multirow[b]{2}{*}{ Well } & \multirow{2}{*}{$\begin{array}{c}\text { Principal } \\
\text { Unit }\end{array}$} & \multirow[b]{2}{*}{ Date } & \multicolumn{15}{|c|}{ Trace Metals (ug/L) } & \multirow{2}{*}{$\begin{array}{c}\text { Separate } \\
\text { Sample }\end{array}$} \\
\hline & & & $\mathrm{Ag}$ & Al & $\mathrm{B}$ & $\mathrm{Ba}$ & $\mathrm{Cd}$ & Co & $\mathrm{Cr}_{\mathrm{r}}$ & $\mathrm{Cu}$ & $\mathrm{Fe}$ & $\mathrm{Mn}$ & Mo & $\mathrm{Ni}$ & Sb & Sr & $\mathrm{Zn}$ & \\
\hline O9N28E05C & USMB & 15-Aug-94 & $\mathbf{u}$ & U & & 39.0 & 4 & $\mathbf{U}$ & U & $\mathrm{U}$ & $\mathrm{u}$ & U & & $\mathrm{u}$ & $u$ & & $u$ & \\
\hline 10N27E23J & USMB & 15-Aug-94 & $u$ & $\mathbf{u}$ & & 74.0 & $u$ & $u$ & $u$ & u) & 53.0 & 42.0 & & $u$ & $u$ & & 66.0 & \\
\hline 10N27E28B & USMB & 15-Aug-94 & $U$ & u) & & 27.0 & $u$ & u & $\mathbf{u}$ & 5.5 & 27.0 & $u$ & & u) & $u$ & & 45.0 & \\
\hline 12N28E23H & USMB & 15-Aug-94 & u & $u$ & & 48.0 & $u$ & $u$ & $u$ & $u$ & 98.0 & 16.0 & & $u$ & $\mathrm{u}$ & & 15.0 & \\
\hline 199-H4-2 & RRI & 25-May-93 & 3.7 & $\mathbf{u}$ & & 70.0 & $u$ & $u$ & $u$ & 4.8 & 17.0 & 1.4 & & $\mathrm{u}$ & $\mathrm{u}$ & & 60.0 & \\
\hline 299-E16-1 & EMI & 26-Aug-92 & 10.0 & 49.0 & & 65.2 & 7.0 & 9.0 & 9.0 & 8.0 & 27.6 & 5.5 & & 20.0 & 60.0 & & 7.0 & \\
\hline 299-E26-8 & RRI & 28-Jun-93 & $\mathrm{u}$ & $u$ & & 51.0 & $\mathrm{u}$ & $u$ & $u$ & $u$ & 120.0 & $u$ & & $u$ & $u$ & & 210.0 & \\
\hline 299-E33-12 & RRI & 26-May-93 & $u$ & $\mathbf{u}$ & & 90.0 & $u$ & $\mathrm{u}$ & $u$ & $\mathrm{u}$ & 50.0 & 1.8 & & $u$ & $u$ & $u$ & 8.5 & $\mathrm{Sr}$ \\
\hline 299-E33-40 & RRI & 23-Jun-93 & $u$ & $\mathbf{u}$ & & 67.7 & u & $u$ & $u$ & $u$ & 66.0 & 99.0 & & $\mathrm{u}$ & $u$ & $u$ & $u$ & $\mathrm{Sr}$ \\
\hline $399-5-2$ & USMB & 6-Apr-95 & $u$ & $u$ & & 71.0 & $u$ & $u$ & 9.0 & $u$ & 470.0 & 56.0 & & $\mathbf{u}$ & $u$ & & $u$ & \\
\hline 699-S11-E12AP & LEVEY & 19Jan-95 & $u$ & $u$ & 50.00 & 50.0 & $u$ & $u$ & $u$ & $u$ & 89.0 & 47.0 & $u$ & $u$ & $u$ & 92.00 & $u$ & $\mathrm{~B}, \mathrm{Mo}, \mathrm{Sr}$ \\
\hline 699-S16-E14 & LEVEY & 4.Jan-80 & & $u$ & 50.00 & 61.0 & & $u$ & $u$ & $U$ & 110.0 & 55.0 & $u$ & U & & 64.00 & 110.0 & \\
\hline 699-S16-E14 & RRI & 23-Jan-80 & & $u$ & 20.00 & 68.0 & & $u$ & $u$ & $u$ & 50.0 & $u$ & $u$ & $\mathbf{u}$ & & 51.00 & 20.0 & \\
\hline $699-17-47$ & EMI & 13Jun-78 & & $u$ & & 97.0 & & $u$ & $u$ & $u$ & 20.0 & 70.0 & $\mathrm{u}$ & $\mathbf{u}$ & & & 50.0 & \\
\hline $699-17-47$ & RRI & 26Jun-78 & & $\mathbf{u}$ & $U$ & 146.0 & & $u$ & $u$ & $u$ & 33.0 & 50.0 & $u$ & u) & & & $\mathrm{u}$ & \\
\hline $699-25-80$ & RRI & 10-Sep-78 & & 140.0 & $U$ & 34.0 & & $u$ & u & $\mathrm{u}$ & $\mathrm{u}$ & $u$ & 130.00 & 16.0 & & & 18.0 & \\
\hline 699-32-22B & EMI & 1 Jun-91 & & & 80.00 & 40.0 & & & & & $u$ & 10.0 & & & & 77.00 & $u$ & \\
\hline 699-42-E9B & RRI & 17-Feb-95 & $u$ & $\mathbf{u}$ & 90.00 & 18.0 & $u$ & $u$ & 5.2 & $u$ & 55.0 & 2.7 & 50.00 & $\mathbf{u}$ & $u$ & & 9.4 & B, Mo \\
\hline $699-42-40 \mathrm{C}$ & EMI & 16-Apr-82 & $u$ & & & 108.0 & & $u$ & uे & $u$ & 2720.0 & 173.00 & & u & & & 186.0 & \\
\hline $699-42-40 \mathrm{C}$ & RAI & 24-Jan-95 & $u$ & 26.0 & & 110.0 & $u$ & $u$ & $u$ & $u$ & 19.0 & 2.5 & & $u$ & $u$ & & $u$ & \\
\hline $699-42-42 A$ & RAI & 13-Jul-93 & $\mathrm{u}$ & $\mathbf{u}$ & & 68.0 & $u$ & $u$ & $u$ & $\mathrm{u}$ & 50.0 & $u$ & & $\mathbf{u}$ & $u$ & & u & \\
\hline $699-47-42$ & RRI & 26-Apr-79 & & 40.0 & $U$ & 120.0 & $u$ & $u$ & U) & u & 20.0 & u & $\mathrm{u}$ & $\mathbf{u}$ & & 160.00 & 100.0 & \\
\hline $699-47-50$ & RRI & 26-May-93 & $u$ & 34.0 & 30.00 & 50.0 & $u$ & $\mathrm{u}$ & $\mathrm{u}$ & $\mathrm{u}$ & 130.0 & 9.3 & $\mathrm{u}$ & u & $u$ & $\mathrm{u}$ & 10.0 & B, Mo, Sr \\
\hline $699-49-558$ & nni & 26̂-ivay-93 & i & 60.0 & & 70.0 & vi & v & 8.9 & $\overline{6} . \overline{9}$ & 1500.0 & 10.0 & & u & $u$ & $\mathrm{u}$ & 200.0 & $\mathrm{Sr}$ \\
\hline 699-49-57B & RAI & 25-May-93 & 3.9 & 50.0 & & 60.0 & $u$ & $u$ & 15.0 & 5.8 & 30.0 & 7.9 & & $u$ & $u$ & $\mathrm{u}$ & 50.0 & $\mathrm{Sr}$ \\
\hline $699-50-45$ & RAI & 24-Aug-94 & $u$ & $u$ & & 41.0 & $u$ & $u$ & 170.0 & 24.0 & 1200.0 & 47.0 & & 120.0 & 26.0 & & 14.0 & \\
\hline $699-50-48 B$ & RRI & 24-Aug-94 & $u$ & 4 & & 36.0 & $u$ & $u$ & $u$ & $u$ & 630.0 & 85.0 & & $u$ & $u$ & & 11.0 & \\
\hline 699-50-53B & ARI & 2-May-95 & 4.1 & 23.4 & & 70.2 & 2.4 & 3.4 & 4.7 & 9.8 & 34.7 & 2.8 & & 15.4 & 26.3 & $\mathrm{u}$ & 16.3 & \\
\hline $699-51-46$ & RAI & 24-Aug-94 & $u$ & $\mathbf{u}$ & & 52.0 & $u$ & $u$ & 4 & $\mathrm{u}$ & 360.0 & 8.1 & & $u$ & $u$ & & 27.0 & \\
\hline $699-52-46 A$ & RAI & 29-Jun-94 & $u$ & $u$ & & 88.0 & $u$ & $u$ & $u$ & $u$ & 49.0 & $\mathrm{u}$ & & u & $\mathrm{u}$ & & $u$ & \\
\hline $699-52-48$ & RRI & 10-May-94 & $\mathrm{U}$ & u & & 40.0 & $u$ & $u$ & $u$ & $u$ & 1100.0 & 22.0 & & $\mathrm{u}$ & u) & & 6.7 & \\
\hline 699-53-50 & RRI & 22-Nov-94 & $u$ & 34.0 & & 38.0 & u & $u$ & 5.1 & $u$ & 1300.0 & 36.0 & & $\mathbf{u}$ & $u$ & & u & \\
\hline $699-54-57$ & RRI & 26-May-93 & $u$ & 4 & & 100.0 & $u$ & $u$ & $u$ & $u$ & 160.0 & 2.9 & & u & $u$ & $u$ & 9.0 & $\mathrm{Sr}$ \\
\hline $699-56-43$ & USMB & 7Jul-94 & $u$ & 4 & & 59.0 & $u$ & $u$ & $u$ & $u$ & 39.0 & 13.0 & & $u$ & $u$ & & $u$ & \\
\hline 699-56-53 & RRI & 18-Jul-94 & $\mathrm{u}$ & 30.0 & & 70.0 & $u$ & $u$ & $u$ & $u$ & 63.0 & 2.7 & & $\mathbf{u}$ & 33.0 & & 9.1 & \\
\hline 699-84-34B & EMI & 22-Jan-80 & & 50.0 & 120.00 & 54.0 & & $u$ & $u$ & $u$ & 160.0 & $u$ & 170.00 & u & & 90.00 & $u$ & \\
\hline 699-84-34B & RPI & 18Van-80 & & 30.0 & u & 61.0 & & $\mathrm{u}$ & $\mathrm{u}$ & $\mathrm{U}$ & 610.0 & $\mathbf{u}$ & 70.00 & $\mathrm{u}$ & & 48.00 & 20.0 & \\
\hline $\begin{array}{l}\text { Dotection Limit } \\
\text { Quantification LimH }\end{array}$ & & & $\begin{array}{l}6.0 \\
20.0 \\
\end{array}$ & $\begin{array}{c}31.0 \\
200.0 \\
\end{array}$ & $\begin{array}{c}5.00 \\
100.00 \\
\end{array}$ & $\begin{array}{c}1.0 \\
20.0 \\
\end{array}$ & $\begin{array}{c}3.0 \\
10.0 \\
\end{array}$ & $\begin{array}{c}7.0 \\
20.0\end{array}$ & $\begin{array}{l}11.0 \\
20.0 \\
\end{array}$ & $\begin{array}{l}4.0 \\
20.0\end{array}$ & $\begin{array}{l}18.0 \\
20.0\end{array}$ & $\begin{array}{c}1.0 \\
10.0\end{array}$ & 8.00 & $\begin{array}{l}16.0 \\
30.0\end{array}$ & $\begin{array}{r}62.0 \\
200.0\end{array}$ & 20.00 & $\begin{array}{l}6.0 \\
10.0\end{array}$ & \\
\hline
\end{tabular}

EMI = Elephaint Mountain Momber Intorflow

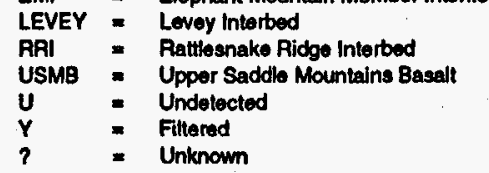


Table A.3. Summary Table of Stable and Unstable Isotopes

\begin{tabular}{|c|c|c|c|c|c|c|c|c|c|c|c|}
\hline \multirow[b]{2}{*}{ Well } & \multirow[b]{2}{*}{$\begin{array}{c}\text { Principal } \\
\text { Unit }\end{array}$} & \multirow[b]{2}{*}{ Date } & \multicolumn{4}{|c|}{ Stable Isotopes } & \multicolumn{4}{|c|}{ Unstable Isotopes } & \multirow[b]{2}{*}{$\begin{array}{l}\text { Separate } \\
\text { Sample }\end{array}$} \\
\hline & & & $\mathrm{H}-2$ & 0.18 & S-34 & C- 13 & $\begin{array}{c}\text { Trilium } \\
\text { (TU) }\end{array}$ & C-14 PMC & $\begin{array}{c}\text { C-14 } \\
\text { err_PMC }\end{array}$ & $1-129 \mathrm{pCin}$ & \\
\hline 09N28E05C & USMB & 15-Aug-94 & -104.0 & -13.4 & 2.2 & -13.5 & 7.3 & 97.90 & -1.10 & & \\
\hline 10N27E23J & USMB & 15-Aug-94 & -114.0 & -14.0 & 4.3 & -11.9 & *19.0 & 61.20 & 0.60 & & \\
\hline 10N27E28B & USMB & 15-Aug-94 & -98.0 & -12.6 & 4.0 & -14.4 & 7.9 & 108.60 & 1.20 & & \\
\hline 12N28E23H & USMB & 15-Aug-94 & -139.0 & -17.7 & 17.2 & -9.9 & $<0.1$ & 0.90 & 0.21 & & \\
\hline $199-\mathrm{H} 4-2$ & RRI & 5-Aug-94 & -157.0 & -20.1 & 3.7 & -12.4 & $<0.1$ & 12.20 & 0.90 & $<1.0 E-00$ & 1-129 \\
\hline 299-E16-1 & EMI & 14-Jul-82 & -140.0 & -16.2 & 7.4 & & $<0.1$ & & & 2.8E-05 & $1-129$ \\
\hline 299-E26-8 & RAI & 28-Jun-93 & -133.0 & -17.5 & 1.8 & -12.1 & 0.1 & 22.91 & 0.18 & 7.7E-06 & 1.129 \\
\hline 299-E33-12 & RAI & 23-Jun-93 & -136.0 & -18.5 & 4.8 & -12.4 & 130.0 & 2233.97 & 24.58 & $3.7 E-02$ & \\
\hline 299-E33-40 & RAI & 23-Jun-93 & .146 .0 & -19.7 & 4.7. & -10.1 & 1.9 & 35.40 & 1.70 & $<1.0 \mathrm{E}-00$ & \\
\hline 399-5-2 & USMB & 1-Sep-94 & -140.0 & -17.9 & IS & -12.8 & $<0.1$ & 6.30 & 0.40 & $<1.0 \mathrm{E}-00$ & \\
\hline 699-S11-E12AP & LEVEY & 12-Aug-94 & -142.5 & -17.9 & IS & -13.8 & $<0.1$ & 7.10 & 0.40 & $1.6 \mathrm{E}-04$ & 1.129 \\
\hline 699-S16-E14 & LEVEY & 4-Jan-80 & -145.0 & -17.3 & & -13.3 & 0.2 & 7.90 & 1.30 & & \\
\hline 699-S16-E14 & RAI & $23 \operatorname{Jan}-80$ & -145.0 & -17.4 & & -16.2 & 0.3 & 4.90 & 1.10 & & \\
\hline $699-17-47$ & EMI & 14-Jun-78 & & -17.1 & & & $<0.1$ & 30.00 & 0.90 & 2.9E-05 & \\
\hline $699-17-47$ & RAI & 26-Jun-78 & & -17.1 & & & 0.2 & 16.20 & 0.70 & $5.0 \mathrm{E}-06$ & \\
\hline $699-25-80$ & RRI & 10-Sep-78 & & -16.1 & & & $<0.1$ & 33.30 & 0.50 & 4.4E-04 & \\
\hline 699-32-22B & EMI & 1-Jun-91 & & & & & $<156.0$ & & & $1.4 \mathrm{E}-04$ & I-129 \\
\hline 699-42-E9B & RAI & 11-Jul-94 & -143.0 & -17.9 & 19.1 & -13.4 & $<1.0$ & 3.00 & 0.80 & $5.2 \mathrm{E}-04$ & 1.129 \\
\hline $699-42-40 \mathrm{C}$ & EMI & 16-Apr-82 & -150.0 & -18.5 & 2.7 & & 374.0 & & & & \\
\hline $699-42-40 \mathrm{C}$ & RAI & 28-Jun-93 & -141.0 & -18.7 & 4.7 & -14.1 & 2481.0 & 156.50 & 2.70 & 8.3E-03 & 1.129 \\
\hline $699-42-42 A$ & RPI & 13-Jul-93 & -142.0 & -18.8 & 29.2 & -15.3 & 32.4 & 15.24 & 0.12 & $<1.0 \mathrm{E}-00$ & \\
\hline $699-47-42$ & RAI & 26-Apr-79 & -152.0 & -17.2 & -10.3 & -13.1 & 10.8 & 19.80 & 0.40 & 2.3E-02 & \\
\hline $699-47-50$ & RAI & 21 Jun.93 & -128.5 & -17.4 & 1.6 & -10.6 & 68.8 & 142.99 & 1.12 & $6.0 \mathrm{E}-03$ & $1-129$ \\
\hline 699-49-55B & RAI & 21 Jun-93 & -132.0 & -18.4 & 5.4 & -12.4 & 1.0 & 52.00 & 1.20 & $5.5 \mathrm{E}-06$ & 1.129 \\
\hline 699-49-57B & RRI & 30-Jun-93 & -136.0 & -18.3 & 5.1 & -11.3 & 5.1 & 70.67 & 0.46 & $<1.0 E-00$ & \\
\hline $699-50-45$ & RRI & 14-Jul-94 & -135.0 & -17.0 & 0.2 & -13.4 & 1.9 & 35.33 & 0.49 & 4.7E-04 & $1-129$ \\
\hline $699-50-48 B$ & RRI & 7-Jul-94 & -135.0 & -16.8 & -1.6 & -9.3 & $<0.1$ & 57.20 & 0.60 & 7.1E-03 & 1.129 \\
\hline 699-50-53B & RAI & 1-Aug-94 & -145.0 & -18.2 & 1.0 & -10.0 & $<0.1$ & 21.30 & 0.50 & $<1.0 \mathrm{E}-00$ & $1-129$ \\
\hline $699-51-46$ & RAI & 15-Jul-94 & -136.0 & -16.4 & 2.5 & -11.1 & $<0.1$ & 20.60 & 0.90 & 2.6E-04 & 1.129 \\
\hline 699-52-46A & RAI & 29-Jun-94 & -135.0 & -16.9 & 1.6 & -13.5 & $<0.1$ & 24.10 & 0.40 & $2.1 \mathrm{E}-04$ & $1-129$ \\
\hline $699-52-48$ & RRI & 1 Jul-94 & -143.0 & -18.2 & 4.8 & -15.0 & $<0.1$ & 7.50 & 0.90 & $5.8 \mathrm{E}-05$ & 1.129 \\
\hline $699-53-50$ & RAI & 1-Aug-94 & -140.0 & $-17,4$ & 1.4 & -12.2 & $<0.1$ & 34.00 & 0.70 & 6.1E-04 & $1-129$ \\
\hline 699-54-57 & RRI & 22-Jun-93 & -139.0 & -18.6 & 4.9 & -12.5 & 0.1 & 36.30 & 1.90 & $1.5 \mathrm{E}-05$ & $1-129$ \\
\hline $699-56-43$ & USMB & 7.Jul-94 & -134.0 & -16.3 & -0.1 & -11.0 & $<0.1$ & 36.70 & 1.80 & $<1.0 E-00$ & 1.129 \\
\hline $699-56-53$ & RAI & 18-Jul-94 & -140.0 & -18.0 & 4.7 & -14.6 & $<0.1$ & 37.00 & 0.70 & $2.3 E-03$ & $1-129$ \\
\hline 699-84-34B & EMI & 22Jan-80 & -147.0 & -18.4 & -4.2 & -11.6 & 0.1 & 5.20 & 1.10 & "2.0E-05 & \\
\hline 699-84-34B & RRI & 18-Jan-80 & -155.0 & -19.1 & & -11.0 & $<0.1$ & 4.00 & 1.20 & "1.1E-05 & \\
\hline
\end{tabular}

EMI = Elephant Mountain Member Interllow

LEVEY = Levey Interbed

RAI - Rattlesnake Ridge Interbed

USMB = Upper Saddio Mountains Basal

is = Insurficient samplo for analysis

$=$ Counting orror not availablo 


\section{Distribution}

No. of

Copies

OFFSITE

A. Aldrich

U.S. Bureau of Land Management

Spokane District Office

1103 North Fancher

Spokane, WA 99212-1275

M. Ault

US Ecology, Inc.

P.O. Box 638

Richland, WA 99352

J. Blanchard

U.S. Bureau of Reclamation

P.O. Box 815

Ephrata, WA 98823

L. Block

U.S. Fish and Wildlife Service

P.O. Box 1157

Moses Lake, WA 98837

R. Buck, Jr.

Wanapum Indian Band

P.O. Box 878

Ephrata, WA 98823

J. Chasse

Washington Public Power Supply System

P.O. Box 968

Richland, WA 99352

R. A. Danielson

Washington State Department of Health

2 South 45th Ave.

Yakima, WA 98908
No. of

Copies

B. Drost

U.S. Geological Survey

1201 Pacific Avenue, Suite 600

Tacoma, WA 98402

J. R. Eliason

Geologic Analysis \& Consulting Services

P.O. Box 309

Deary, ID 83823

2 Environmental Planning/Rights Protection

Confederated Tribes of the Umatilla Indian Reservation

P.O. Box 638

Pendleton, OR 97801

ATTN: T. Gilmore

J. R. Wilkerson

2 Environmental Restoration/Waste

Management

Nez Perce Tribe

P.O. Box 365

Lapwai, ID 83540-0365

ATTN: D. Powaukee

S. Sobczyk

C. B. Forster

Earth Sciences and Resources Institute University of Utah

151.5 East Mineral Square - Suite 138

Salt Lake City, UT 84112

A.J.K. Fyall

Benton County Planning Department

P.O. Box 910

Prosser, WA 99350 
No. of

\section{Copies}

J. Hansen, Mayor

City of Richland

545 Swift Blvd.

Richland, WA 99352

W. E. Hathhorn

Washington State University

Department of Civil and Environmental Engineering

Pullman, WA 99164-2910

R. Isaacson, Chairman

Benton County Commissioners

P.O. Box 190

Prosser, WA 99350

R. Jim

Yakama Indian Nation

Environmental Restoration/Waste

Management

P.O. Box 151

Toppenish, WA 98948

J. Leier

U.S. Army Corps of Engineers

Walla Walla District

Building 602, City-County Airport

Walla Walla, WA 99362-9265

\section{J. Mann}

U.S. Geological Survey, WRD

P.O. Box 2230 - MS-4148

Idaho Falls, ID 83403

R. Patt

Oregon State Department of Water

Resources

3850 Portland Road

Salem, OR 97310
No. of

Copies

J. A. Riley

Pyrite Hydrochem

P.O. Box 453

4560 East Highland Drive

Post Falls, ID 83854-0453

M. Sabol

U.S. Environmental Protection Agency

1200 Sixth Ave., WD-133

Seattle, WA 98101

South Columbia Basin Irrigation District 402 W. Lewis Street

Pasco, WA 99301

3 U.S. Department of Energy-Headquarters 1000 Independence Ave., S.W.

Washington, D.C. 20585

ATTN: J. S. Bachmaier, EH-412

J. O. Boda, EM-322

M. Harmon, EM-442

T. Walker

Kennewick City Council

210 W. 6th Ave.

Kennewick, WA 99336

3 Washington State Department of Ecology

P.O. Box 47600

M.S. 7600

Olympia, WA $98504-7600$

ATTN: C. Cline

J. Stohr

T. Wintzcak

2 Washington State Department of Health Division of Radiation Protection P.O. Box 47827

Olympia, WA 98504-7827

ATTN: M. Dunkleman

J. Erickson 
No. of

Copies

M. A. Wilson

Washington State Department of Ecology 1315 4th Avenue

Kennewick, WA 99336

\section{ONSITE}

13 DOE Richland Operations Office
G. M. Bell
R. F. Birch
M. J. Furman
C. H. Gunion
J. B. Hall
R. D. Hildebrand (2)
R. G. Holt
R. G. McLeod
P. M. Pak
M. J. Plahuta
R. K. Stewart
K. M. Thompson

14 Bechtel Hanford, Inc.

K. R. Fecht

B. H. Ford

G. C. Henckel, III

G. L. Kasza

A. J. Knepp

M. J. Lauterbach

K. D. Lyso

D. A. Myers

D. L. Parker

J. W. Roberts

L. C. Swanson

J. S. Treadwell

S. J. Trent

D. C. Weekes

3 CH2M-Hill

J. V. Borghese

R. L. Jackson

R. E. Peterson
A5-52

A5-19

R3-81

H4-83

A5-55

H4-83

A5-15

A5-19

A5-19

A7-75

A5-19

A5-19

H4-80

H6-07

H6-07

H6-04

H4-80

H6-01

H4-79

H4-79

H6-02

H6-03

H6-03

H4-79

H4-80

H6-07

H6-04

H6-04

H6-05
No. of

Copies

U.S. Army Corps of Engineers

M. P. Blanca

3. U.S. Environmental Protection Agency

P. R. Beaver

B5-01

L. E. Gadbois

B5-01

D. R. Sherwood

B5-01

12 Westinghouse Hanford Company

D. B. Barnett

H6-06

M. G. Gardner

N3-06

E. M. Greager

H6-20

M. J. Hartman

H6-06

D. G. Horton

H6-06

V. G. Johnson

H6-06

J. E. Meisner

$\mathrm{N} 1-55$

R. B. Mercer

H6-06

S. P. Reidel

H6-06

J. S. Schmid

H6-06

J. A. Serkowski

Public Reading Room

H6-06

58 Pacific Northwest Laboratory

M. P. Bergeron

K6-77

R. W. Bryce

K9-34

C. R. Cole

K6-96

J. L. Devary

K6-96

P. E. Dresel

K6-96

J. C.. Evans

K6-96

M. D. Freshley

K6-77

R. E. Gephart

K1-22

T. J Gilmore

K6-84

P. C. Hays/B. V. Johnston

K9-41

G. V. Last

K6-84

P. E. Long

K6-84

S. P. Luttrell (10)

K6-96

J. P. McDonald

K6-96

Q. C. Macdonald

K6-96

D. R. Newcomer

K6-96

R. Schalla 
No. of

Copies

R. M. Smith K6-96

F. A. Spane, Jr. (15) K6-96

S. S. Teel K6-84

P. D. Thorne K6-96

V. R. Vermeul K6-96

W. D. Webber (5) K6-96

S. K. Wurstner K6-77

Information Release Office (7) K1-06 